Fungal Divers. 2011 December 1; 51(1): 189-248. doi:10.1007/s13225-011-0143-8.

\title{
A reappraisal of Microthyriaceae
}

\author{
Hai X. Wu, \\ International Fungal Research and Development Centre, Key Laboratory of Resource Insect \\ Cultivation \& Utilization State Forestry Administration, The Research Institute of Resource \\ Insects, Chinese Academy of Forestry, Kunming 650224, People's Republic of China
}

Conrad L. Schoch,

National Center for Biotechnology Information, National Library of Medicine, National Institutes of Health, 45 Center Drive, MSC 6510, Bethesda, MD 20892-6510, USA

\section{Saranyaphat Boonmee,}

School of Science, Institute of Excellence in Fungal Research, Mae Fah Luang University Tasud, Muang, Chiang Rai 57100, Thailand

\author{
Ali H. Bahkali, \\ Botany and Microbiology Department, College of Science, King Saud University, Riyadh 11442, \\ Saudi Arabia \\ Putarak Chomnunti, and \\ School of Science, Institute of Excellence in Fungal Research, Mae Fah Luang University Tasud, \\ Muang, Chiang Rai 57100, Thailand

\begin{abstract}
Kevin D. Hyde
International Fungal Research and Development Centre, Key Laboratory of Resource Insect Cultivation \& Utilization State Forestry Administration, The Research Institute of Resource Insects, Chinese Academy of Forestry, Kunming 650224, People's Republic of China. School of Science, Institute of Excellence in Fungal Research, Mae Fah Luang University Tasud, Muang, Chiang Rai 57100, Thailand. Botany and Microbiology Department, College of Science, King Saud University, Riyadh 11442, Saudi Arabia
\end{abstract}

Kevin D. Hyde: kdhyde3@gmail.com

\section{Abstract}

The family Microthyriaceae sensu Lumbsch and Huhndorf 2010 is a poorly known but interesting family comprising 50 genera consisting of foliar epiphytes or saprobes on dead leaves and stems. We re-visited the family based on examinations of generic types where possible. Members are distributed in Aulographaceae, Asterinaceae, Microthyriaceae, Micropeltidaceae and Palmulariaceae and notes are provided on each of these families. Nine genera are transferred from Microthyriaceae to Asterinaceae, and two to Aulographaceae based on the splitting or dissolving nature of the thyriothecia to release ascospores. New sequence data for a number of species and genera are provided. Microthyriaceous members growing on other fungi and lichens differ from Microthyriaceae sensu stricto and the family Trichothyriaceae is reinstated to accommodate these taxa. Other genera of Microthyriaceae belong in Rhytismataceae, Stictidaceae, Venturiales incertae cedis, Dothideomyetes genera incertae cedis, Hypocreales incertae cedis and Ascomycota genera incertae cedis. The family Microthyriaceae is reduced to seven genera characterised by

\footnotetext{
(C) Kevin D. Hyde 2011

Correspondence to: Kevin D. Hyde, kdhyde3@gmail. com.

Electronic supplementary material The online version of this article (doi:10.1007/s13225-011-0143-8) contains supplementary material, which is available to authorized users.
} 
superficial, flattened thyriothecia, with the cells of the upper wall radiating in parallel arrangement from the distinct central ostiolar opening, while the lower peridium is generally poorly developed. Sequence data is provided for five species with thyriothecia and Paramicrothyrium and Neomicrothyrium are described as new genera and Micropeltis zingiberacicola is introduced as a new species. Our phylogenetic analysis underscores the high genetic diversity for thyriotheciate species and there is no clear clade that can be well defined as Microthyriales. Nuclear ribosomal data support multiple polyphyletic lineages within Microthyriaceae and Micropeltidaceae. Some unexpected DNA based phylogenetic relationships such as those between Muyocopron and Saccardoella will require corroboration with more complete taxon sampling as well as additional non ribosomal markers. There are few differences between Aulographaceae, Asterinaceae and Palmulariaceae and these families may need synonymising.

\section{Keywords}

Asterinaceae; Aulographaceae; Dothideales; Leaf fungi; Micropeltidaceae; Molecular phylogeny; Trichothyriaceae

\section{Introduction}

The Microthyriaceae is a poorly known but interesting family comprising 50-54 genera which are foliar epiphytes or most likely saprobes on the dead leaves and stems (Müller and von Arx 1962; Ellis 1976; Ramaley 1999; von Arx and Müller 1975; Barr 1987; Hawksworth et al. 1995; Kirk et al. 2008; Lumbsch and Huhndorf 2010; Wu et al. 2010, 2011a, b). The important morphological characters of Microthyriaceae are superficial, flattened, ascomata, known as thyriothecia, with the cells of the upper wall radiating in parallel arrangement from the distinct central ostiolar opening, while the lower peridium is generally poorly developed. The thyriothecia contain fusiform, obclavate to cylindroclavate, bitunicate and fissitunicate asci, while ascospores are mainly 2-celled, hyaline or brown (Ryan 1924; Luttrell 1973; von Arx and Müller 1975; Barr 1987; Spooner and Kirk 1990).

\section{Historic overview of Microthyriaceae}

Saccardo (1883) established the family Microthyriaceae which included six sections and nine genera with dimidiate, flattened superficial, blackened, ascomata, comprising radiating cells which could be distinguished from each other according to the colour, size and number of septa of the ascospores. Theissen (1913) introduced the order of Hemisphaeriales to accommodate three families; Trichopeltulaceae (with multilocular ascomata covered by radiating arranged cells); Microthyriaceae (with unilocular ascomata with radiating arranged cells and more or less superficial mycelium); and Hemisphaeriaceae (with unilocular ascomata without radiating cells). Arnaud (1918) established a new order Microthyriales which included Microthyriaceae and Microthyriopsidaceae. Microthyriaceae was divided into different tribes according to the form, presence or absence of superficial mycelium and hamathecium characters (Arnaud 1918). Luttrell (1973) followed Theissen (1913) using the order Hemisphaeriales to include 11 families: Asterinaceae, Aulographaceae, Brefeldiellaceae, Leptopeltidaceae, Micropeltidaceae, Microthyriaceae, Munkiellaceae, Parmulariaceae, Stephanothecaceae, Schizothyriaceae and Trichopeltinaceae.

In their re-evaluation of the bitunicate ascomycetes with keys to families and genera, von Arx and Müller (1975) revisited Microthyriaceae and placed it into the order Dothideales. This was subdivided into two suborders; Dothideineae and Pseudosphaeriineae. Pseudosphaeriineae included families with ostiolate ascomata and elongate or cylindrical 
asci such as species of Microthyriaceae and Micropeltidaceae; Dothideineae was characterized by non-ostiolate ascomata, which rupture irregularly when mature to discharge ascospores as in species of Schizothyriaceae and Asterinaceae. Barr (1987) placed the Microthyriaceae in the order Melanommatales and the Micropeltidaceae in the order Pleosporales which were placed into the subclass Loculoedaphomycetidae depending on the type of hamathecium. Kirk et al. (2008) annotated the order Microthyriales as comprising Aulographaceae, Microthyriaceae and Leptopeltidaceae, Lumbsch and Huhndorf (2010) placed Microthyriaceae in Dothideomycetes as families incertae cedis.

Kirk et al. (2008) state that Microthyriales is poorly known and probably polyphyletic, but until now there was very little molecular data to confirm this statement. This view is tested in the analysis we present in this study. An additional objective of the present study is to revisit Microthyriaceae sensu Lumbsch and Huhndorf (2010) by examining generic types and suggest placements and requirements for future work. In this way it will be possible to recollect the genera and obtained fresh cultures for epitypification and molecular work. We have also made new collections which have been sequenced and provide new data on the Microthyriaceae and morphologically similar families and genera such as Micropeltidaceae. As a result of this study we also deal with Asterinaceae, Aulographaceae, Palmulariaceae and Micropeltidaceae.

\section{Materials and methods}

Type specimens of genera were obtained from K, FH, PDD, URM, BPI, S, M, BISH, KRA, NY, ILL, IMI, LISE, YAM, LPS (for full names of herbaria see http://sweetgum.nybg.org/ih/index.php). Ascomata were rehydrated in 3\% $\mathrm{KOH}$ prior to examination and sectioning. Specimens were examined under a stereo microscope (Leica MZ16A) and fine forceps were used to remove one or two ascomata, which were mounted in water, Melzer's reagent and Congo red, or cotton blue stains. Observations and photographs were made under Nikon E800 and Leica DM3000 light microscopes. For some hyaline structures differential interference contrast microscopy was used. Hand sections were cut with a sharp razor blade and thin $(8 \mu \mathrm{m})$ sections were cut using a Leica CM1100 freezing microtome. The sections were transferred to a drop of water or a drop of cotton blue for examination and photography. Morphological characters were defined as in the important literature (Barr 1987; Luttrell 1973; von Arx and Müller 1975; Spooner and Kirk 1990; Ryan 1924, 1926).

The use of terminology mainly follows Zhang et al. (2009, 2011, 2012), however, we use the term thyriothecia to mean a flattened circular structure, usually with a central ostiole and poorly develop peridium at the base which can usually easily be removed from the substrate. It is not always clear whether the fungus derives its nutrients from the host or is a saprobe obtaining nutrients from the air or rain runoff. We therefore use the term foliar epiphyte when we are not sure if it is a biotroph or saprobe, biotrophic when we have shown evidence or have obtained evidence from the literature that mycelia or hyphopodia penetrate the host and thus should obtain nutrients. We use saprobic if developing on dead leaves. Biotrophic fungi have generally been hard to isolates however, we have been successful in isolating some species using the method of Chomnunti et al. (2011). There are also two types of ostiole mentioned in this paper. The prominent circular ostiole usually with a darkened rim as found in Microthyrium and the dissolving, dehiscence or cracking of the upper wall to release ascospores as found in Asterinaceae or Palmulariaceae (Ignácio and Cannon 2008).

\section{Sequence alignment and phylogenetic analyses}

The phylogeny was performed with two markers: partial sequence from the small and large subunits of the nuclear ribosomal RNA genes (SSU, LSU). Sequences were downloaded 
from GenBank according to Supplementary Table 1. The individual genes were aligned with SATé (Liu et al. 2009) using MAFFT (Katoh et al. 2009) as the external sequence alignment tool and RAxML (Stamatakis 2006) as the tree estimator. Sequence alignments were parsed with Gblocks (Castersana 2000) following non conservative settings: the maximum number of contiguous nonconserved positions was set to 8 , the minimum length blocks set to five 5 , allowing for gap positions in half the sequences. Previous results indicated no clear conflict amongst the majority of the data used (Schoch et al. 2009) and phylogenetic analyses of the single genes did not yield conflicts in clades with RAxML bootstrap presence above $70 \%$. Therefore sequences were concatenated in BioEdit (Hall 1999). We compared analyses of alignments with and without GBlock exclusions and noted no significant difference but we only present an analysis using the more conserved alignment. This resulted in $10.64 \%$ missing and gap characters out of a total set of 1729 characters (956 obtained from SSU and 773 obtained from LSU). The final data matrix had 75 taxa including outgroups (Supplementary Table 1). The final analysis was performed at the CIPRES webportal (Miller et al. 2010) using RAxML v. 7.2.8as part of the "RAxML-HPC2 on TG" tool (Stamatakis 2006; Stamatakis et al. 2008) applying unique model parameters for each gene (2 partitions). A general time reversible model (GTR) was applied with a discrete gamma distribution and four rate classes. Fifty thorough maximum likelihood (ML) tree searches were done in RAxML v. 7.2.7 under the same model, each one starting from a separate randomized tree and the best scoring tree selected with a final ln value of -19043.637742 . A single species of Arthoniomycetes, the sister class to Dothideomycetes, (Schismatomma decolorans) was used as outgroup. One thousand non parametric bootstrap iterations were run with the GTR model and a discrete gamma distribution. The resulting replicates were plotted on to the best scoring tree obtained previously. The phylogram with bootstrap values above the branches is presented in Fig. 1 by using graphical options available in TreeDyn v. 198.3 (Chevenet et al. 2006).

We also analyzed the same data set mentioned previously using the Bayesian method of Huelsenbeck et al. (2001) by implementing Markov Chain Monte Carlo (MCMC) sampling using the software MrBayes v.3.1.2 (Huelsenbeck and Ronquist 2001) at the CIPRES webportal. Data was partitioned as in the RAxML run and the same likelihood models were applied with four discrete gamma categories. The Bayesian prior distributions treated all trees as equally likely. Two parallel runs were performed with four chains each. Every 100th tree was saved. The Bayesian analysis halted after 2873000 generations when the average standard deviation of split frequencies across runs was lower than $0.01(=0.00998)$. We considered the two runs to have converged and a majority rule consensus tree was constructed from the 28730 resultant trees in each run. The first $50 \%$ of each run was discarded as burn in and the remaining two sets of combined. The best scoring RAxML tree was used as a template and the percentage presence of all nodes within the combined set of trees plotted on its nodes as Bayesian posterior probabilities. These are indicated as the second set of values above the nodes in Fig. 1.

\section{Results}

The phylogenetic analysis in Fig. 1 uses representative sequences from all orders in the class Dothideomycetes. The analysis did not recover the nodes supporting subclasses, Pleosporomycetidae and Dothideomycetidae in all bootstrap resamplings but previous studies with support for those nodes included additional protein coding genes (Schoch et al. 2006, 2009). We included a number of species with thyriothecia in this analysis (highlighted in bold). In addition to the newly generated sequences associated with this study we added a number of sequences already deposited in GenBank (see Supplementary Table 1). 
Stomiopeltis versicolor forms part of a diverse group of fungi isolated from apples with symptoms of flyspeck and sooty blotch (Díaz Arias et al. 2010). This species grouped in a clade sister to Dissoconiaceae with other species associated with this disease complexhyphomycetes Phaeothecoidiella illinoisensis and Houjia yanglingensis (Yang et al. 2010). The polyphyletic state of Stomiopeltis, as currently circumscribed, is confirmed by the placement of Stomiopeltis betulae sister to Microthyrium microscopicum in Fig. 1.

Divergent sequences identified as Micropeltis zingiberacicola and Paramicrothyrium chinensis further highlight genetic diversity for species with thyriothecia. Neomicrothyrium siamense showed some affinity for a set of species recently described in the novel freshwater genus Natupusilla (Ferrer et al. 2011) with no obviously similar morphological characters. Another unsuspected relationship with few shared morphologies, but in this case with both high bootstrap and Bayesian posterior probability was found for sets of sequences identified as Muyocopron sp. and Saccardoella rhizophila. The latter species was isolated from mangrove prop roots (Hyde 1992). The final species with thyriothecia used in our analysis, Tothia fuscella clustered with good support within Venturiales. In most cases species with thyriothecia resided on long branches although care was taken to remove the most divergent parts of our alignment.

\section{Key to families and orders with thyriothecia discussed in this paper}

1. Thyriothecia lacking a distinct layer at the base, biotrophs and saprobes on leaves and stems

1. Thyriothecia with a distinct peridium layer at the base, growing on lichens and other fungi

2. Thyriothecia with a distinct central rounded ostiole

2. Thyriothecia lacking a distinct rounded ostiole, but upper wall cracking, dissolving or dehiscing to form a linear or star-like or irregular central ostiole or gelatinous opening

3. Thyriothecia with a distinct darkened, circular central ostiole, upper wall comprising neatly arranged parallel cells, asci narrowly obclavate to long fusiform, ascospores one septate, hyaline, with or without appendages or with cilia at the ends

3. Thyriothecia with a central circular ostiole, lacking a darkened rim, blue green blue black to black, upper wall comprising non radiate, flattened, often meandrous interwoven cells, asci clavate to cylindrical or elongate, asci developing inclined towards the center of thyriothecia, ascospores trans-septate, usually with more than two septa

4. Thyriothecia opening with an irregular pore or starlike dehiscence or dissolving to form a gelatinous mass, asci globose to saccate, ascus surface may blue in IKI Asterinales (consider Asterinaceae and Palmulariaceae)

4. Thyriothecia opening with a slit-like pore, ascus surface not bluing in IKI
2

Trichothyriaceae

3. "Microthyriales"

4.

Microthyriaceae

Micropeltidaceae

Aulographaceae

Details of treatments of Microthyriaceae by Müller and von Arx (1962) and Barr (1987) are given in Table 1. Lumbsch and Huhndorf (2010) included 50 genera in Microthyriaceae (Table 1) and this basically follows Hawksworth et al. (1995) which is turn follows the arrangement in various Outlines of the Ascomycetes in Systema Ascomycetum, the latter where most additional genera were introduced to the family.

\section{Taxonomic treatment}

A summary of the taxonomictreatmentsinthis paperare provided in Table 2.

\section{Microthyriales G. Arnaud}

Foliar epiphytes, biotrophs or saprobes on living or dead leaves and stems of various plants. Thyriothecia relatively small (100 $\mu \mathrm{m}$ diam) to very large $(1 \mathrm{~mm}$ diam $)$, flattened, circular, light brown, brown, black, blue green or blue black, usually with a central ostiole and with a poorly developed basal layer, which can usually easily be removed from the substrate.

Upper wall comprising neatly arranged parallel cells or meandering hyphae or tightly joined lobed cells or mostly of mycelium. Ostiole prominent, circular, usually with a darkened rim 
as found in Microthyrium or less prominent as found in Micropeltidaceae.

Pseudoparaphyses often present and distinct, sometimes deliquescing and lacking. Asci 4-8spored, bitunicate, fissitunicate, pedicellate, without a distinct ocular chamber, not bluing IKI. Ascospores 2-celled, or with many transverse septa, hyaline or brown. Anamorphs: coelomycetous.

Microthyriales was introduced by Arnaud (1918) and was subsequently considered superfluous by Luttrell (1973), von Arx and Müller (1975) and Barr (1987). In fact usage of the order has been limited to Kirk et al. (2001, 2008). Schoch et al. (2009) used a single strain in their analysis of Dothideomycetes and labeled this in their dendrogram as Microthyriales. Lumbsch and Huhndorf (2010) treated Microthyriaceae and Micropeltidaceae as families in Dothideomycetes family incertae cedis, however Index Fungorum (http://www.indexfungorum.org/names/Names.asp) and (MycoBank http://www.mycobank.org/MycoTaxo.aspx) have retained the use of Microthyriales. In this study we add five new sequences from Microthyriaceae-like taxa none of which can be found in a single clade. The clearest support is found for a clade containing Microthyrium microscopicum and Stomiopeltis betulae. If these sequences are authentic this may represent a clade that could be defined as Microthyriales at the ordinal level. However, at this point the phylogeny does not provide us with enough clarity to propose this placement or support the order Microthyriales.

Microthyriaceae Sacc

Muyocopronaceae Luttr. [as 'Myiocopronaceae'], Univ. Mo. Stud. 24(3): 87 (1951), illegitimate name, Art 36.1

Foliar epiphytes, biotrophs or saprotrophs on leaves of various plants. Superficial mycelium if present, brown, septate, some with hyphopodia, some mycelium forming haustoria. Thyriothecia superficial, relatively small (less than $200 \mu \mathrm{m}$ diam), flattened, dimidiate, having an upper wall of neatly arranged cells which radiate from the prominent often darkened circular central ostiole in a somewhat parallel arrangement, with a poorly developed basal layer. Pseudoparaphyses often present and distinct, sometimes deliquescing and lacking. Asci 8-spored, bitunicate, fissitunicate, elongate fusiform to cylindrical, with or without a pedicel, with an ocular chamber or ocular not distinct, not bluing in IKI. Ascospores usually 1-septate, ovoid, fusiform to ellipsoidal, or clavate, sometimes with cilia or appendages which may be hard to observe, hyaline, or becoming brown when mature.

Anamorphs: Asterostomula anamorphic Asterinella; Asteromella-like, anamorphic Asterinella; Eriothyrium (possible link to Asterinema), Leptothyrium, anamorphic Microthyrium; Xenogliocladiopsis anamorphic Arnaudiella (Doidge 1942; Kirk et al. 2001, 2008; Hyde et al. 2011).

Kirk et al. (2008) estimated there are 54 genera and 278 species in the family. Following this study we accept seven genera (Table 1) and approximately 220 species (based on estimates for species in genera in Kirk et al. 2008).

The most distinctive family characteristic in Microthyriaceae is the thyriothecium (Doidge 1942; Müller and von Arx 1962; Luttrell 1973; Barr 1987; Hofmann and Piepenbring 2006; Hofmann 2010). In Microthyriaceae this is a typically flattened, dimidiate ascoma, having an upper wall of neatly arranged cells which radiate from the central, darkened, prominent ostiole in a somewhat parallel arrangement, but the wall is thin as the base (Fig. 2b, c). Thyriothecia in Microthyriaceae are relatively small, and some can easily be removed from the host surface; asci and pseudoparaphyses are arranged from a hymenium around the periphery of the ascomata and grow inwards towards the ostiole. The asci are bitunicate, 
fissitunicate, fusiform, obclavate to cylindro-clavate and ascospores are mostly two-celled. In recent studies and in this paper, Tothia and Muyocopron with thyriothecia typical of Microthyriaceae cluster outside this family (KoKo et al., personal communication; Wu et al. 2011 b; Fig. 1) and this character appears to have evolved on more than one occasion. Various authors have also included genera with quite different characters in Microthyriaceae, generally but not always with thyriothecia in common. Therefore the family is presently confused. In this treatment we restrict Microthyriaceae to the species with characters similar to Microthyrium with thyriothecia made up of cells radiating from the central ostiole, fusiform, obclavate to cylindro-clavate asci and bicelled hyaline or brown ascospore types which may or may not be ciliate.

We provisionally include Arnaudiella, Calothyriopsis, Caribaeomyces, Microthyrium, Palawania, Paramicrothyrium and Seynesiella in Microthyriaceae. Sequence data suggest that even this restricted treatment may be polyphyletic (Fig. 1) with several sequences identified as Microthyrium placed in concert with seemingly unrelated species or unresolved, so additional changes to this concept is anticipated.

\section{Type genus}

Microthyrium Desm., Annales des Sciences. Naturelles, 3 séries, Botanique., 15: 137 (1841).

Calothyriella Höhn., Ber. dt. bot. Ges. 35: 251 (1917).

Microthyrina Bat., Publções Inst. Micol. Recife 260: 51 (1960).

Phragmothyrium Höhn., Sber. Akad. Wiss. Wien, Math.-naturw. K1., Abt. 1 121: 347 [9 repr.] (1912).

Saprobic mostly on the upper surface of leaves, appearing as very small black spots. Mycelium superficial, abundant, comprising almost colourless, branched, septate hyphae, with subcuticular haustoria. Thyriothecia circular, solitary or gregarious, superficial, membranaceous or slightly carbonaceous, light brown to brown, with a poorly developed basal layer, easily separated from host surface, with a prominent darker central ostiole; in section lenticular. Upper wall comprising cells of textura epidermoidea, radiating outwardly in parallel rows from the darker central ostiole. Peridium comprising a single stratum of cells, outer cells of small heavily pigmented cells of textura epidermoidea, inner cells light brown textura angularis. Hamathecium comprising asci inclined from the base and rim towards the central ostiole, pseudoparaphyses not observe. Asci numerous, 8-spored, bitunicate, fissitunicate, narrowly obclavate to long fusiform, with small knob-like pedicel or pedicel lacking, ocular chamber not apparent, not staining blue in IKI. Ascospores overlapping 2-3-seriate, fusiform to ellipsoidal, hyaline, 1-septate, fine appendages sometimes present, smooth-walled.

Anamorphs reported for the genus: Leptothyrium (Hyde et al. 2011), Zalerion (Ramaley 1999).

\section{Type species}

Microthyrium microscopicum Desm., Annales des Sciences Naturelles, 3 séries, Botanique 2 15: 138 (1841) Fig. 2a-1

Saprobic mostly on the upper surface of leaves, appearing as very small black spots (Fig. 2a). Mycelium superficial, abundant, comprising almost colourless, branched, septate hyphae, with subcuticular haustoria. Thyriothecia 120-190 $\mu \mathrm{m}$ diam $\times 36-50 \mu \mathrm{m}$ high, 
circular, solitary or gregarious, superficial, membranaceous or slightly carbonaceous, light brown to brown, with a poorly developed basal layer, easily separated from host surface, with a prominent darker central 7.5-10 $\mu \mathrm{m}$ diam ostiole; in section lenticular (Fig. 2b). Upper wall comprising cells of textura epidermoidea, radiating outwardly in parallel rows from the darker central ostiole (Fig. 2b, c, d). Peridium 5-15 $\mu \mathrm{m}$ thick, comprising a single stratum of cells, outer cells of small heavily pigmented cells of textura epidermoidea, inner cells light brown textura angularis (Fig. 2f). Hamathecium comprising asci inclined from the base and rim towards the central ostiole, pseudoparaphyses not observed, possibly deliquescing early. Asci 37-55×5-9 $\mu \mathrm{m}(\bar{x}=43.5 \times 6.8 \mu \mathrm{m}, n=15)$, numerous, 8 -spored, bitunicate, fissitunicate, narrowly obclavate to long fusiform, with small knob-like pedicel or pedicel lacking, ocular chamber not apparent, not staining blue in IKI (Fig. 2g-j). Ascospores 12-16×2-3 $\mu \mathrm{m}(\bar{x}=14.4 \times 2.5 \mu \mathrm{m}, n=20)$, overlapping 2-3-seriate, fusiform to ellipsoidal, hyaline, 1 -septate, not constricted at the septum, cilia not seen in type specimen but reported by others, usually with 1 or 2 guttules, smooth-walled (Fig. 2i, k, 1, m).

Anamorph: None reported.

Material examined: FRANCE, Parc de Libisny, on the upper leaf surface of Castanea (Fagaceae), September 1840, M. Rorberge (Desm. Cryp. France exs. 1092) (K (M): 163346, isotype); UK, Herefordshire, Forest of Dean, on dead leaves of Quercus robur (Fagaceae) September 2010, K.D. Hyde (MFLU09-0653).

Microthyrium was formally established by Desmazières (1841) based on ascomata with a radiating structure, called thyriothecia. It is the type genus of Microthyriaceae, and is a widely distributed genus with a wide host range (Ellis 1976; Ramaley 1999). Desmazières (1841) described Microthyrium microscopicum from Castanea sativa and later added leaves of Buxus sempervirens and Quercus ilex as hosts to this species (Ellis 1976). Ellis (1976) described British Microthyrium species and similar fungi, and re-described and illustrated the type species of Microthyrium microscopicum. Ellis (1976) examined the type collection on a leaf Castanea vulgaris and found mature ascospores with apical cilia, and commented that the cilia are sometimes visible, depending on the material and slide preparation.

Recent estimates of the Microthyrium species are ten (von Arx and Müller 1975) or 57 (Kirk et al. 2008), while there are 188 names in Index Fungorum (http://www.indexfungorum.org/). Three new Microthyrium species from dead leaves of Nolina have been described by Ramaley (1999). Two species had appendaged ascospores, while the other lacked appendages, Ramaley (1999) also described the anamorph of Microthyrium guadalupensis as Zalerion guadalupensis A.W. Ramaley. Ramaley (1999) noted that ascospore appendages are present in several species, but it is not known if they occur in all species. More than 20 species have been removed to other genera or their placement in Microthyrium has been questioned, but the majority remains in the genus (Ramaley 1999). A Leptothyrium anamorph has also been reported for the genus (Kirk et al. 2008; Hyde et al. 2011).

As the familial type of Microthyriaceae (and Microthyriales), Microthyrium has particular significance in defining this poorly known family. Morphological characters of significance include the upper ascomatal wall of neatly arranged cells radiating in a parallel fashion from the prominent darkened central ostiole, bitunicate and fissitunicate elongate fusiform asci and two-celled hyaline ascospores often with cilia (Ellis 1976). In phylogenetic analyses of Dothideomycetes, a single strain of Microthyrium microscopicum was the only member of Microthyriaceae/Microthyriales used in the analysis of Schoch et al. (2009) where it formed a unique lineage. In this paper we add sequences of three more taxa (Fig. 1) which illustrates 
the polyphyletic nature of this family as well as its type genus. This highlights the need of a monograph for the genus with well validated molecular data.

A recent collection of Microthyrium microscopicum (Fig. 3a-1) from oak leaves (Quercus robur) collected in the UK is also illustrated. The appendages can clearly be seen in this species. We tried several times to obtain fresh cultures from this collection but ascospores did not germinate and no sequence data could be obtained from this specimen.

Arnaudiella Petr., Annls mycol. 25(3/4): 339 (1927)

Seynesiola Speg., Boln Acad. nac. Cienc. Córdoba 23: 498 (1919).

Saprobic on stems forming small dark spots, superficial mycelium absent. Thyriothecia subglobose to circular, solitary, scattered, or in small groups of two, superficial, membranaceous, or slightly carbonaceous, black to black brown, lower peridium poorly developed, with a central, slightly raised, prominent, darkened, papilla up to $19 \mu \mathrm{m}$ high, easily separated from host surface; in section subconical. Upper wall comprising rows of cuboid radiating cells which form parallel lines from the central ostiole to the outer rim. Peridium comprising a single substratum of 3-4 layers of compressed brown-walled ellipsoidal cells of textura angularis. Hamathecium of parallel arranged asci inclined from the base and rim towards the central ostiole and sparse pseudoparaphyses. Asci 8-spored, bitunicate, fissitunicate, obclavate, short pedicellate, ocular chamber not obvious, not bluing in IKI. Ascospores overlapping uniseriate or biseriate, oval to broad ellipsoidal with rounded ends, brown, two-celled, smooth-walled.

Anamorphs reported for the genus: Xenogliocladiopsis (Crous and Kendrick 1994).

\section{Type species}

Arnaudiella caronae (Pass.) Petr., Annls mycol. 25(3/4): 339 (1927) Fig. 4a-m

$\equiv$ Seynesia caronae Pass.

Saprobic on stems of Cytisus purgans forming small dark spots (Fig. 4a). Superficial mycelium absent. Thyriothecia $60-97 \mu \mathrm{m}$ high $\times 66-93 \mu \mathrm{m}$ diam, subglobose to circular, solitary, scattered, or in small groups of two, superficial, membranaceous, or slightly carbonaceous, black to black brown, lower peridium poorly developed, with a central, slightly raised, prominent, darkened, papilla up to $19 \mu \mathrm{m}$ high, easily separated from host surface; in section subconical (Fig. 4b-d). Upper wall comprising rows of cuboid radiating cells which form parallel lines from the central ostiole to the outer rim (Fig. 4b-d). Peridium 6-8 $\mu \mathrm{m}$ wide at apex and 10-15 $\mu \mathrm{m}$ wide at the base, comprising a single substratum of 3-4 layers of compressed brown-walled ellipsoidal cells of textura angularis (Fig. 4f). Hamathecium of parallel arranged asci inclined from the base and rim towards the central ostiole and sparse $2 \mu \mathrm{m}$ broad pseudoparaphyses (Fig. 4h). Asci 45-55×9-13 $\mu \mathrm{m}$ $(\bar{x}=50.2 \times 10 \mu \mathrm{m}, n=15), 8$-spored, bitunicate, fissitunicate, obclavate, with short pedicel 4-5 $\mu \mathrm{m}$ long $\times 3-4 \mu \mathrm{m}$ wide, ocular chamber not obvious, not bluing in IKI (Fig. $4 \mathrm{i}-\mathrm{k}$ ). Ascospores $10.5-14 \times 4-6 \mu \mathrm{m}(\bar{x}=12.1 \times 4.8 \mu \mathrm{m}, n=20)$, overlapping uniseriate or biseriate, oval to broad ellipsoidal with rounded ends, brown, two-celled, not constricted at the septum, smooth-walled (Fig. 41-m).

Anamorph: Xenogliocladiopsis (Crous and Kendrick 1994).

Material examined: FRANCE, Pyrénées, Superbolquere, on stem of Cytisus purgans, July 1944, K.H. Rechinger, Reliquiae Petralianae 405 (PDD 54414). 
Arnaudiella was established by Petrak (1927) as a monotypic genus and placed in Microthyriaceae based on the easily separating thyriothecia with a central ostiole, bitunicate obclavate asci and two-celled brown asco-spores. There are 13 records of Arnaudiella in Index Fungorum (http://www.indexfungorum.org/), while Kirk et al. (2008) estimate there are three or six species in the genus. There have been a few studies on this genus. We were unable to locate the type material and used a collection of $\mathrm{H}$. Rechinger from PDD. Müller and von Arx (1962) illustrated the genus with three species, but did not examine the generic type, while Swart (1986) described and illustrated several Microthyrium-like fungi and redescribed Arnaudiella bancroftii Hansf. Crous and Kendrick (1994) described A. eucalyptorum from Eucalyptus leaves in South Africa with a Xenogliocladiopsis eucalyptorum Crous \& Kendr. hyphomycetous anamorph. Arnaudiella bancroftii Hansf. (Hansford 1956) is also known from Eucalyptus and has slightly larger ascospores and lacks a sheath (Crous and Kendrick 1994). Arnaudiella has its closest relative in Seynesiella (Swart 1986). These two genera share similar coloured ascospores and thyriothecia. Arnaudiella is presently placed in to Microthyriaceae (Lumbsch and Huhndorf 2010). Thyriothecia in Tothia are similar to those in Arnaudiella, although the arrangement of cells differs; asci and ascospores are also somewhat similar. Tothia did not cluster in Microthyriaceae in molecular analysis of Wu et al. (2011b) and therefore the status and placement of Arnaudiella also needs confirming based on molecular data. The genus should therefore be maintained in Microthyriaceae with a question mark and should be the subject of a future monograph as it is almost certainly polyphyletic.

Calothyriopsis Höhn., Sber. Akad. Wiss. Wien, Math.-naturw. Kl., Abt. 1 128: 552 (1919)

Ptychopeltis Syd., Annls mycol. 25(1/2): 78 (1927)

Biotrophic on the upper surface of leaves forming very small circular spots. Mycelium superficial, without lateral hyphopodia, but with irregular hyphopodia-like branches which penetrate the host epidermal cells. Thyriothecia circular, scattered, superficial, membranaceous or a slightly carbonaceous, black to black-brown, basal peridium poorly developed, ostiole not clear, dissolving; in section lenticular. Upper wall consisting of loose irregularly arranged parallel cells from the central ostiole to the outer rim. Peridium of two strata, outer layer composed of black-brown pseudoparenchy-matous cells of compact textura prismatica and inner layer composed of light-brown cells of textura angularis. Hamathecium of parallel arranged asci inclined towards the central ostiole and short branching pseudoparaphyses embedded in mucilage. Asci 8-spored, bitunicate, fissitunicate, obclavate, apedicellate and lacking a distinct ocular chamber, not bluing in IKI. Ascospores overlapping biseriate, oval, mostly rounded at the ends, hyaline, two-celled, the upper cell wider than lower cell, rough-walled.

\section{Anamorphs reported for the genus: None.}

\section{Type species}

Calothyriopsis conferta (Theiss.) Höhn., Sber. Akad. Wiss. Wien, Math.-naturw. Kl., Abt. 1 128: 552 (1919) Fig. 5a-1

$\equiv$ Microthyrium confertum Theiss., Annls mycol. 7(4): 352 (1909)

Biotrophic on the upper surface of leaves forming very small circular spots. Mycelia superficial, without lateral hyphopodia, but with irregular hyphopodia-like branches which penetrate the host epidermal cells (Fig. 5c). Thyriothecia 550-830 $\mu \mathrm{m}$ diam $\times 29-42 \mu \mathrm{m}$ high, circular, scattered, superficial, membranaceous or a slightly carbonaceous, black to blackbrown, basal peridium poorly developed, ostiole not clear, dissolving; in section lenticular. Upper wall consisting of loose irregularly arranged parallel cells from the central ostiole to 
the outer rim (Fig. 5a, b, c). Peridium 8-11 $\mu$ m wide, two strata, outer layer composed of black-brown pseudoparenchymatous cells of compact textura prismatica and inner layer composed of light-brown cells of textura angularis (Fig. 5e). Hamathecium of parallel arranged asci inclined towards the central ostiole, and short branching pseudoparaphyses embedded in mucilage (Fig. 5g, h). Asci 45-59×16-18.5 $\mu \mathrm{m}(\bar{x}=52 \times 17.6 \mu \mathrm{m}, n=15), 8$ spored, bitunicate, fissitunicate, obclavate, apedicellate and lacking a distinct ocular chamber, not bluing in IKI (Fig. 5h-j). Ascospores 10.5-13×5-9 $\mu \mathrm{m}(\bar{x}=11.5 \times 6.8 \mu \mathrm{m}$, $n=20$ ), overlapping biseriate, oval, mostly rounded at the ends, hyaline, two-celled, constricted at central septum, the upper cell wider than lower cell, rough-walled (Fig. $5 \mathrm{~g}$ ).

Anamorph: None reported.

Material examined: BRAZIL, Rio Grande do Sul, Sao Leopoldo, on living leaf of Heteropteridis sp., 1 June 1936, F. Theissen no 36 (FH 258806, holotype).

Calothyriopsis was formally established by Höhnel (1919) as a monotypic genus represented by $C$. conferta and was placed in Microthyriaceae. Calothyriopsis roupalae (Syd.) Arx, C. pouteriae Bat. \& Cavalc. and C. mali Subhedar \& V.G. Rao have since been added to the genus (Batista et al. 1967; Subhedar 1980). Müller and von Arx (1962), von Arx and Müller (1975) and Lumbsch and Huhndorf (2010) all place Calothyriopsis in Microthyriaceae. Calothyriopsis, like many genera in the Microthyriaceae have circular thyriothecia with superficial hypha, a central ostiole, obclavate asci and two-celled ascospores. The arrangement of the cells of the thyriothecium is however, roughly parallel and unlike the neat arrangement in Microthyrium and there is no distinct ostiole as in Asterinaceae and therefore the genus should be questionably included in Microthyriaceae. Fresh collection, epitypification and molecular analysis are needed to confirm the relationships of this genus.

Caribaeomyces Cif., Atti Ist. bot. Univ. Lab. crittog. Pavia, Ser. 5 19: 98 (1962)

Calopeltis Toro, Annls mycol. 32(1/2): 110 (1934)

Biotrophic on upper surface of leaves, not forming leaf spots and hyphae not penetrating into the plant cells, superficial mycelium present, with hyphopodia. Thyriothecia circular, gregarious or solitary, superficial, crustose to subcarbonaceous, brown to black, basal peridium poorly developed, with a central dehiscing irregular rounded ostiole; in section lenticular. Upper wall consisting of radially arranged angular cells in parallel lines. Peridium comprising two strata, outer cells pseudoparenchymatous, pigmented thick wall, tightly arranged, inner cells of textura prismatica, pale brown. Hamathecium comprising asci inclined towards the central ostiole, pseudoparaphyses not observed. Asci 4-spored, bitunicate, fissitunicate, obclavate, apedicellate, apically rounded, ocular chamber not apparent, not bluing in IKI. Ascospores overlapping biseriate, clavate, upper cell wider and shorter than lower cell, hyaline, two-celled, septum central, with guttules in each cell, wall smooth.

Anamorphs reported for the genus: None.

\section{Type species}

Caribaeomyces tetrasporus (Toro) Cif. [as 'tetraspora'], Atti Ist. bot. Univ. Lab. crittog. Pavia, Ser. 5 19: 98 (1962) Fig. 6a-i $\equiv$ Calopeltis tetraspora Toro, Annls mycol. 32(1/2): 110 (1934)

Biotrophic on upper surface of leaves, not forming leaf spots and hyphae not penetrating into the plant cells, superficial mycelium present, brown, 5.4-6.8 $\mu \mathrm{m}$ wide. Hyphopodia 
9.5-13.7 $\mu \mathrm{m}$ broad, circular, lateral and alternative, sparse and brown (Fig. 6d). Thyriothecia $130-270 \mu \mathrm{m}$ diam $\times 22-36 \mu \mathrm{m}$ high, circular, gregarious or solitary, superficial, crustose to subcarbonaceous, brown to black, basal peridium poorly developed, with a central dehiscing irregular rounded ostiole; in section lenticular (Fig. 6a-c). Upper wall consisting of radially arranged angular cells in parallel lines, which are less branched at the margin, cells 7.9-15.4 $\mu \mathrm{m}$ long, 4.2-6.5 $\mu \mathrm{m}$ wide (Fig. 6b, c). Peridium 7-13 $\mu \mathrm{m}$ thick, comprising two strata, outer cells pseudoparenchymatous, pigmented thick wall, tightly arranged, inner cells of textura prismatica, pale brown (Fig. 6e). Hamathecium comprising asci inclined towards the central ostiole, pseudoparaphyses not observed. Asci 35-55×9-13 $\mu \mathrm{m}(\bar{x}=42.9 \times 11 \mu \mathrm{m}$, $n=15$ ), 4-spored, bitunicate, fissitunicate, obclavate, apedicellate, apically rounded, ocular chamber not apparent, not bluing in IKI (Fig. 6f, h, i). Ascospores 9-16×3-4 $\mu \mathrm{m}(\bar{x}=13 \times 3.5$ $\mu \mathrm{m}, n=20$ ), overlapping biseriate, long ellipsoidal to clavate, upper cell wider and shorter than lower cell, hyaline, two-celled, septum central and slightly constricted, with guttules in each cell, wall smooth (Fig. 6g).

Anamorph: None reported.

Material examined: DOMINICAN REPUBLIC, Eastern Cordillera, near Paramo de Fontibon, on Symploci theiformis (Symplocaceae), 16 September 1932, Carlos E. Chardón (BPI 698559B, isotype).

Caribaeomyces was formally established by Ciferri (1962) as a monotypic genus represented by Caribaeomyces tetrasporus (Chardón and Toro 1934). Ciferri (1962) considered Caribaeomyces to be distinct because ascoma have a central dehiscing ostiole, the upper ascoma wall comprises radiating arranged of cells, hyphopodia are alternating and lateral, asci are bitunicate and ascospores are cylindrical to ellipsoid, and two-celled. Ciferri (1962) assigned the genus to Microthyriaceae and this is followed by subsequent authors including Lumbsch and Huhndorf (2010). Caribaeomyces is characteristic of the Microthyriaceae in having dimidiate thyriothecia with radiating cells, and bitunicate cylindrical asci and bicelled ascospores, however the central dehiscing rounded ostiole is more typical of Asterinaceae. There have been no molecular investigations of this genus which is questionably maintained in Microthyriaceae.

Palawania Syd. \& P. Syd., Philipp. J. Sci., C, Bot. 9: 171 (1914).

Saprobic on the surface of stem appearing as black spots, superficial hyphae absent. Thyriothecia conical or hemispherical, gregarious, or some solitary, superficial, carbonaceous, brown to black, basal peridium poorly developed, with a dehiscing central stellate ostiole; in section lenticular. Upper wall comprising rows of angular radiating cells which form parallel lines from the central ostiole to the outer rim. Peridium thick, blackbrown, comprised of two strata, outer layer of black cells of textura epidermoidea, inner layer composed of textura angularis comprising compact brown cells. Hamathecium comprising asci and pseudoparaphyses inclined toward the central ostiole. Asci 8-spored, bitunicate, fissitunicate, fusiform to clavate, with a short pedicel, lacking a distinct ocular chamber, not bluing in IKI. Ascospores overlapping 2-3-seriate, fusiform to ellipsoidfusiform, ends slightly pointed, 2-celled, hyaline, becoming brown at maturity, smoothwalled, surrounded by a hyaline sheath.

Anamorphs reported for the genus: None.

\section{Type species}

Palawania grandis (Niessl) Syd. \& P. Syd., Philipp. J. Sci., C, Bot. 9(2): 171 (1914). Fig. $7 \mathrm{a}-\mathrm{m}$ 
$\equiv$ Microthyrium grande Niessl, in Rabenhorst, Fungi europ. exsicc.: no. 2467 (1876).

Saprobic on the surface of stem appearing as black spots, superficial hyphae absent (Fig. 7a). Thyriothecia 310-480 $\mu \mathrm{m}$ diam, 86-110 $\mu \mathrm{m}$ high, conical or hemispherical, gregarious, or some solitary, superficial, carbonaceous, brown to black, basal peridium poorly developed, with a dehiscing central stellate ostiole; in section lenticular (Fig. 7b, c, d) Upper wall comprising rows of angular radiating cells which form parallel lines from the central ostiole to the outer rim (Fig. 7c, d). Peridium 13-16 $\mu \mathrm{m}$, thick, black-brown, comprised of two strata, outer layer of black cells of textura epidermoidea, inner layer composed of textura angularis comprising compact brown cells (Fig. 7e, f, m). Hamathecium comprising asci and $1.5-2 \mu \mathrm{m}$ broad, branched and filamentous pseudoparaphyses embedded in mucilage inclined toward the central ostiole (Fig. 7h). Asci 80-86×24-30 $\mu \mathrm{m}(\bar{x}=84.5 \times 28$ $\mu \mathrm{m}, n=$ ?), 8 -spored, bitunicate, fissitunicate, fusiform to clavate, with a short pedicel, lacking a distinct ocular chamber, not bluing in IKI (Fig. 7g, i, j). Ascospores 26-31×9-15 $\mu \mathrm{m}(\bar{x}=28.5 \times 12.2 \mu \mathrm{m}, n=$ ?), overlapping 2-3-seriate, fusiform to ellipsoid-fusiform, ends slightly pointed, 2-celled, slightly constricted at the septum, hyaline, becoming brown at maturity, smooth-walled, surrounded by a hyaline sheath (Fig. 7k, 1).

Anamorph: None reported.

Material examined: INDIA, Calcutta, on Calamus sp., collection time not cited, S. Kurz 3802, Rabenhorst, Fungi Europaei 2467 (M-0155393, holotype); (S, F8214; F90149; F8873, isotypes).

Palawania was introduced by Sydow and Sydow (1914) with $P$. grandis and $P$. cocoës and placed into the family Microthyriaceae. There are eight species epithets in Index fungorum (http://www.indexfungorum.org/Names/Names.asp), while Kirk et al. (2008) estimate there is only one species. Palawania grandis is similar to Microthyrium in having a similar parallel arrangement of cells in the thyriothecium; however it differs in the stellate ostiole, copious pseudoparaphyses and brown ascospores, which are characteristic of Asterinaceae. We follow Müller and von Arx (1962) and Lumbsch and Huhndorf (2010) in placing Palawania in Microthyriaceae until fresh collections can be obtained and molecular analysis can confirm the relationship of this distinct genus.

Paramicrothyrium H.X. Wu \& K.D. Hyde, gen. nov. MycoBank 563363

Similis generis Microthyrium sed ascomata ostiole irregulares et asci cylindrico-clavati.

Etymology: From the Greek para meaning near or compared with, in reference to the similarity to Microthyrium.

Saprobic on the upper surface of leaves, superficial mycelium absent. Thyriothecia circular, gregarious, membranaceous, dark brown, basal layer poorly developed, with an irregular central ostiole; in section lenticular. Upper wall comprising radiating parallel angular cells, cells at margin branching. Peridium comprising two strata, outer cells of textura epidermoidea, inner cells of textura angularis (Fig. 8e). Hamathecium comprising numerous asci inclined toward the central ostiole, pseudoparaphyses not observed or lacking. Asci 8spored, bitunicate, fissitunicate, cylindrical to cylindro-clavate, pedicellate. Ascospores uniseriate, fusiform-clavate, apex hyaline, one-septate, possibly ciliate, smooth-walled.

\section{Type species}

Paramicrothyrium chinensis H.X. Wu \& K.D. Hyde, sp. nov. Fig. 8a-o

MycoBank 563364

Fungal Divers. Author manuscript; available in PMC 2012 December 1. 
Thyriothecia $420-590 \mu \mathrm{m}$ diam $\times 38-59 \mu \mathrm{m}$ alta, circularia, gregaria, membranacea, atro brunnea, ostiolatia irregularia. Asci 77.2-106.5×7.8-11.7 $\mu \mathrm{m}(\bar{x}=95.3 \times 8.9 \mu \mathrm{m}, n=15), 8$ spori, bitunicati, fissitunicati, cylindrici vel cylindro-clavati, breve pedicellati. Ascosporae $14.8-16.5 \times 4.7-5.9 \mu \mathrm{m}(\bar{x}=15.6 \times 5.1 \mu \mathrm{m}, n=20)$, uniseriatae, fusiformis-clavatae hyalinae, one septatae.

Etymology: in reference to its association (Latin-ensis) with China=chinensis.

Saprobic on the upper surface of leaves, superficial mycelium absent (Fig. 8a, b). Thyriothecia 420-590 $\mu \mathrm{m}$ diam $\times 38-59 \mu \mathrm{m}$ high, circular, gregarious, membranaceous, dark brown, basal layer poorly developed, with an irregular central ostiole; in section lenticular (Fig. 8a-c). Upper wall comprising radiating parallel angular cells, cells at margin branching (Fig. 8c, d). Peridium 6-12 $\mu \mathrm{m}$ thick, comprising two strata, outer cells pseudoparenchymatous comprising small heavily pigmented cells of textura epidermoidea, inner cells comprising light pigmented brown-walled cells of textura angularis (Fig. 8e).

Hamathecium comprising numerous asci inclined toward the central ostiole, pseudoparaphyses not observed or lacking. Asci $77.2-106.5 \times 7.8-11.7 \mu \mathrm{m}(\bar{x}=95.3 \times 8.9 \mu \mathrm{m}$, $n=15), 8$-spored, bitunicate, fissitunicate, cylindrical to cylindro-clavate, with a short $5.3 \times 4.1 \mu \mathrm{m}$ pedicel, ocular chamber not observed (Fig. 8f-i). Ascospores $14.8-16.5 \times 4.7-$ $5.9 \mu \mathrm{m}(\bar{x}=15.6 \times 5.1 \mu \mathrm{m}, n=20)$, uniseriate, fusiform-clavate with region above central septum swollen and wider, apex slightly papillate, basal cells subconical, hyaline, one septate, not constricted at the septum, possibly with cilia at the ends, smooth-walled (Fig. $8 \mathrm{j}-\mathrm{O})$.

Material examined: CHINA, Guizhou Province, MaoLan, on dead leaves of unidentified plant, 5 January 2010, Wu haixia (IFRD 8987, holotype); extype culture IFRDCC2258.

Paramicrothyrium is introduced to accommodate a Microthyrium-like taxon from China. The genus differs from Microthyrium as asci are cylindro-clavate and the ostiole is irregular and lacks a prominent darkened ring as in Microthyrium. According to the phylogenetic analysis this taxon does not cluster with the clade of Microthyrium microscopicum.

Seynesiella G. Arnaud, Annals d'École National d'Agric. de Montpellier, Série 2 16(1-4): 202 (1918) [1917]

Foliar epiphyte on pinnae of conifers, superficial mycelium absent. Thyriothecia subglobose, broadly conical or circular, solitary or scattered, superficial, carbonaceous, shiny black to black, lower peridium poorly developed, with a dehiscent stellate central ostiole; in section conical. Upper wall comprising neatly arranged radiating cells. Peridium a single stratum, comprising dark-brown cells of textura angularis. Hamathecium comprising asci and pseudoparaphyses embedded in mucilage inclined toward the central ostiole. Asci 8-spored, bitunicate, fissitunicate, clavate to broad cylindrical, pedicellate, ocular chamber not apparent, not staining blue in IKI. Ascospores overlapping biseriate, ellipsoidal to ovate, ends rounded, hyaline when young, light brown when mature, two celled, the upper cell wider than the lower cell, wall smooth.

Anamorphs reported for the genus: None.

\section{Type species}

Seynesiella juniperi (Desm.) G. Arnaud, Annals d'École National d'Agric. de Montpellier, Sér. 2 16(1-4): 203 (1918) Fig. 9a-g

$$
\equiv \text { Asterina juniperi (Desm.) Jacz. }
$$


三 Dothidea juniperi Desm. Annls Sci. Nat., Bot., sér. 2: 13 (1841).

$\equiv$ Hysterostoma juniperi (Desm.) Bat. \& Peres, Saccardoa 1: 94 (1960)

$\equiv$ Microthyrium juniperi (Desm.) Sacc., Michelia 1(no. 3): 350 (1878)

三 Seynesia juniperi (Desm.) F. Stevens, Annls mycol. 15(5): 373 (1939)

Foliar epiphyte on pinnae of conifers, superficial mycelium absent. Thyriothecia $84-110 \mu \mathrm{m}$ high $\times 170-280 \mu \mathrm{m}$ diam, subglobose, broadly conical or circular, solitary or scattered, superficial, carbonaceous, shiny black to black, lower peridium poorly developed, with a dehiscent stellate central ostiole; in section conical (Fig. 9a-g). Upper wall comprising neatly arranged radiating cells (Fig. 9b, c). Peridium 10-28 $\mu \mathrm{m}$ thick, a single stratum, comprising dark-brown cells of textura angularis (Fig. 9e, f). Hamathecium comprising asci and 1.5-2 $\mu \mathrm{m}$ broad, branched and filamentous pseudoparaphyses embedded in mucilage inclined toward the central ostiole (Fig. 9i). Asci 57-72×17-25 $\mu \mathrm{m}(\bar{x}=64.9 \times 20.6 \mu \mathrm{m}, n=15)$, 8 -spored, bitunicate, fissitunicate, clavate to broad cylindrical, with a $14.5 \times 4.5 \mu \mathrm{m}$ pedicel, ocular chamber not apparent, not staining blue in IKI (Fig. 9h-k). Ascospores 16-21×5-7 $\mu \mathrm{m}(\bar{x}=18.4 \times 6.1 \mu \mathrm{m}, n=20)$, overlapping biseriate, ellipsoidal to ovate, ends rounded, hyaline when young, light brown when mature, two celled, slightly constricted at the septum, the upper cell wider than the lower cell, wall smooth (Fig. 91-n).

Anamorph: None reported.

Material examined: CANADA, Ontario, Lambton County, on living and dead needles of Juniperus communis (Cupressaceae), 14 July 1927, J. Dearness (PDD 29019); FRANCE, without location, on lower part of living leaves of Juniperus sp., Desmazieres Cryp. France exs. 1094 (K (M)164151, syntype)

Seynesiella was introduced as a monotypic genus by Arnaud (1918) represented by Seynesiella juniperi and placed in Venturiaceae by Müller and von Arx (1962). Barr (1987) was confident this genus should be placed in Microthyriaceae alongside Microthyrium and this proposal is followed in Lumbsch and Huhndorf (2010). Four species have been added to the genus (Bigelow and Barr 1969; Müller and von Arx 1962; Sivanesan and Vánky 2002), and Kirk et al. (2008) estimate there are four species. Seynesiella appears to be closely related to Microthyrium as the thyriothecia comprise an arrangement of radiating cells, bitunicate asci, and two-celled ascospores, but the brown ascospores in Seynesiella can distinguish the two genera as Microthyrium species have hyaline ascospores (Sivanesan and Vánky 2002). The lack of distinct ostiole is also typical of Asterinaceae. Perhaps this genus is most similar to Tothia and Arnaudiella. Molecular data is needed to confirm this arrangement.

\section{Genera transferred to Micropeltidaceae Clem. \& Shear}

The Micropeltidaceae is rather unique as ascomata comprise thyriothecia which develop superficially or in the outer cuticle on usually green living leaves of hosts and mycelium are superficial and do not appear to penetrate the host (von Arx and Müller 1975). Introduced by Clements and Shear (1931) this family has been accepted by von Arx and Müller (1975) with eight genera, Barr (1987) with five genera, Kirk et al. (2008) with 27 genera and Lumbsch and Huhndorf (2010) with 24 genera. Besides the monographs of Batista (1959) the family is rather poorly known and studied. Although resembling Microthyriaceae in having thyriothecia, Micropeltidaceae can be readily distinguished by the mostly bluishgreen colour and structure of the peridium and long clavate ascospores with mostly more than two transverse septa. The pseudoparaphyses are narrowly cellular but tend to deliquesce in mature specimens and are not always present as distinguishing characters. In 
the generic type, Micropeltis applanata, the peridium of the often bluefish-green thyriothecia comprises an irregular meandering arrangement of compact hyphae, while the ascospores are long clavate with up to eight transverse septa.

In this study we accept Micropeltidaceae as a distinct family and describe the generic type (Micropeltis applanata). Byssopeltis and Scolecopeltidium are transferred to the family while a monograph of the family will be provided in a later paper.

Micropeltis Mont., in Sagra, Historia física, polirica y nayturál de la islea de Cuba: 325 (1842) [1838-1842]

Dictyothyriella Rehm, in Theissen, Brotéria, sér. bot. 12: 92 (1914)

Hormopeltis Speg., Anal. Mus. nac. Hist. nat. B. Aires 23: 84 (1912)

Micropeltella Syd. \& P. Syd., Annls mycol. 11(5): 404 (1913)

Micropeltidium Speg., Boln Acad. nac. Cienc. Córdoba 23(3-4): 575 (1919)

Ophiopeltis J.V. Almeida \& Sousa da Câmara, Revta agron., Lisb. 1: 175 (1903)

Parapeltella Speg., Boln Acad. nac. Cienc. Córdoba 23(3-4): 506 (1919)

Scolecopeltella Speg., Algunos Hong. Portoriq.: 22 (1923)

Scolecopeltis Speg., Boln Acad. nac. Cienc. Córdoba 11(4): 574 (1889)

Scolecopeltopsis Höhn., Sber. Akad. Wiss. Wien, Math.-naturw. Kl., Abt. 1 118: 316 [42 repr.] (1909)

Theciopeltis F. Stevens \& Manter, Bot. Gaz. 79: 285 (1925)

Foliar epiphyte on the lower surface of leaves, superficial mycelium absent or not observed. Thyriothecia circular, gregarious, superficial, membraneous, bluish or greenish to black, lower peridium poorly developed, easily removed from the host surface, with a central irregular ostiole; in section lenticular. Upper wall comprising of an irregular meandering arrangement of compact hyphae. Peridium black to light brown, comprising two strata, outer cells black and compact, inner cells comprising loosed light brown cells of textura angularis. Hamathecium comprising asci embedded in mucilage and asci inclined toward the central ostiole, pseudoparaphyses sparse or evanescent. Asci 6-8-spored, bitunicate, fissitunicate, obclavate to widely fusiform, pedicellate, ocular chamber not obvious, not bluing in IKI. Ascospores 2-3-overlapping seriate, hyaline, long clavate, trans-septate, smooth-walled.

Anamorphs reported for the genus: Scarcely known, pycnothyriaceous taxa associated with species of Stomiopeltis (Farr 1987).

\section{Type species}

Micropeltis applanata Mont., Annls Sci. Nat., Bot., sér. 2 17: 325 (1842) Fig. 10a-n

Foliar epiphyte on the lower surface of leaves, superficial mycelium absent or not observed. Thyriothecia 280-330 $\mu \mathrm{m}$ diam $\times 35-50$ high, circular, gregarious, superficial, membraneous, bluish or greenish to black, lower peridium poorly developed, easily removed from the host surface, with a central irregular ostiole; in section lenticular (Fig. 10a-f). Upper wall comprising an irregular meandering arrangement of compact hyphae (Fig. 10d). Peridium 5$10 \mu \mathrm{m}$ wide, black to light brown, comprising two strata, outer cells black and compact, inner cells comprising loosed light brown cells of textura angularis. Hamathecium comprising asci embedded in mucilage and asci inclined toward the central ostiole, 
pseudoparaphyses sparse or evanescent, (Fig. 10f, j). Asci $65-95 \times 15-25 \mu \mathrm{m}(\bar{x}=78.4 \times 20.3$ $\mu \mathrm{m}, n=15), 6-8$-spored, bitunicate, fissitunicate, obclavate to widely fusiform with a 5-6×7$8 \mu \mathrm{m}$ pedicel, ocular chamber not obvious, not bluing in IKI (Fig. 10g-i). Ascospores 30.5$35 \times 5-8 \mu \mathrm{m}(\bar{x}=32.8 \times 5.7 \mu \mathrm{m}, n=20), 2-3-$ overlapping seriate, hyaline, long clavate, (4-) 5 $(-8)$ septate, constricted at the septum, smooth-walled (Fig. 10k-n).

Anamorph: None reported.

Material examined: CUBA, Ramon de la Sagra, near Cayennam, on leaves of Laurus (Lauraceae), unknown collection date, Leprieur No 1134 (PC 0097156, isotype); CUBA, no location or date (PC 0097156, lectotype designated here); CUBA, no location or date, ex herb Montage in herb. Berkeley (K, 164010, isotype).

Micropeltis was formally established by Montagne (1842) with a description the type species $M$. applanata and presently 260 names are listed in Index Fungorum (http://www.indexfungorum.org/Names/Names.asp). In a monograph of the taxon, Batista (1959) recognized 89 species and 2 varieties in Micropeltis. Micropeltis differs from Microthyrium in having blue-green to brown-black thyriothecia, with a peridium comprising an irregular meandering arrangement of compact hyphae with a central ostiole. and multiseptate long clavate ascospores. Batista (1959) used the color of ascomata as major character to separate species into five groups. Due to the variation of color and size of thyriothecia, ascospore length and width, and the number of septa were used to distinguish species by Reynolds and Gilbert $(2005,2006)$. Micropeltis is the type genus of Micropeltidaceae (Lumbsch and Huhndorf 2010).

The specimen from Montagne's herbarium in $\mathrm{P}$ is confusing as it contains two samples, one with the location annotation with the same details as the protologue (from Ramon de la Sagra) and another just stating from Cuba. Neither gave the name of the host. The former is a single quarter of a leaf with very few larger ascomata while the second contains several smaller leaves with numerous but slightly smaller ascomata. In the isotype from $\mathrm{K}$, there is a small section of the larger leaf with a single ascomata and one smaller leaf with many ascomata. This is part of the type from $\mathrm{P}$ and seems like Berkeley had the same dilemma. The contents of the larger ascomata are not in good condition, while those of the smaller ascomata are in good condition. Both are obviously Micropeltis but it is not clear if they are different species or represent different developmental stages of the same species. Montagne's? drawing in the herbarium packet does also not help solve the dilemma. We therefore designate the collection with good material as lectotype and describe and illustrate this collection.

A second collection of Micropeltis was made from leaves of a zingiberaceous plant (probably Alpinia) in southern China and only differs from Micropeltis applanata in having smaller 4-septate as compared to larger 5-septate ascospores. The only species we can find recorded from Zingiberaceae is Micropeltis ekmanii Petr. \& Cif. (Ferrer et al. 2011) and this species has much wider ascospores (24-33×7-9 $\mu \mathrm{m}$ ) with 5-septa (Petrak and Ciferri 1932). We could not find any species in the monograph of Micropeltis by Batista (1959) that had ascospores with similar dimensions and the same number of septa. It is important that we give a name for the first sequences of Micropeltidaceae in GenBank and therefore introduce this as a new species. In the molecular analysis this species clusters with the order of Botryosphaeriales but without any meaningful statistical support so this relationship is likely spurious.

Micropeltis zingiberacicola H.X. Wu \& K.D. Hyde, sp. nov Fig. 11a-1

MycoBank 563365 
Fungus similis Micropeltis applanata Petr. \& Cif., sed ascosporis 17.5-24.4×3.2-5.1 et 5septatis et hospes differ.

Etymology: in reference to loving (cola) it host Zingiberaceae.

Foliar epiphyte on the lower of surface leaves, superficial mycelium absent. Thyriothecia 50-96 high $\times 380-480 \mu \mathrm{m}$ diam, circular, gregarious, superficial, membraneous, bluish to black, basal peridium poorly developed, easily removed from the host surface, with an irregular centre ostiole; in section lenticular (Fig. 11a-d). Upper wall comprising an irregular meandering arrangement of compact hyphae (Fig. 11a-d). Hamathecium comprising asci embedded in mucilage and asci inclined toward the central ostiole, pseudoparaphyses not observed (Fig. 11e, f). Asci 47.7-59.5×10.7-13.2 $\mu \mathrm{m}(\bar{x}=51.9 \times 12.7$ $\mu \mathrm{m}, n=15$ ), 8-spored, bitunicate, fissitunicate, fusiform, with a short pedicel, ocular chamber not observed, not bluing in IKI (Fig. 11g-j). Ascospores 17.5-24.4×3.2-5.1 $\mu \mathrm{m}(\bar{x}=$ $21.3 \times 4.3 \mu \mathrm{m}, n=20$ ), overlapping 2-3-seriate, clavate, hyaline, 4-septate, constricted at the septum, smooth-walled (Fig. 11k, l).

Material examined: CHINA, Yunnan Province, on fresh Alpinia? leaves, 6 August 2010, H.X. Wu haixia (IFRD 8988, holotype) extype culture IFRDCC 2264.

Byssopeltis Bat., J.L. Bezerra \& T.T. Barros, Publções Inst. Micol. Recife 636: 5 (1970) [1969]

\section{Type species}

Byssopeltis maranhensis Bat., J.L. Bezerra \& T.T. Barros, Publicações. Instituto de Micologia da Universidade de Pernambuco 636: 6 (1970) Fig. 12a-i

Foliar epiphyte on the lower surface of leaves, forming small spots, superficial mycelium present. Thyriothecia $75-100 \mu \mathrm{m}$ high $\times 730-940 \mu \mathrm{m}$ diam, circular, scattered, superficial, membranaceous, brown to black, basal peridium poorly developed, with an irregular central ostiole; in section lenticular (Fig. 12a-e). Upper wall comprising an irregular meandering arrangement of compact hyphae (Fig. 12c, e). Peridium 24-30 $\mu \mathrm{m}$ wide, a single stratum, comprising brown-black cells of compact textura angularis. Hamathecium of dense, parallel asci inclined from the base and rim towards the central ostiole, with pseudoparaphyses shorter than asci, embedded in mucilage (Fig. 12d, h). Asci 70-109×18-30 $\mu \mathrm{m}(\bar{x}=93.2 \times 25.8$ $\mu \mathrm{m}, n=15)$, 4-spored, bitunicate, fissitunicate, broadly clavate, with a $20-15 \times 10-15 \mu \mathrm{m}$ pedicel and 20-26×13-15 $\mu \mathrm{m}$ ocular chamber, not bluing in IKI (Fig. 12f, i). Ascospores 50-57 $\times 8.5-9 \mu \mathrm{m}(\bar{x}=54 \times 8.9 \mu \mathrm{m}, n=20)$, biseriate or overlapping triseriate, long clavate, rounded and wide at the apex and tapering towards the base, hyaline, two-celled, constricted at septum, with the upper cell wider and shorter than lower cell, with rough ornamentation (Fig. 12g).

Material examined: BRAZIL, Maranhenses, on undetermined leaves, 14 December 1966, José de Audieta (URM 40121, holotype).

Byssopeltis was established by Batista et al. (1970) as a monotypic genus represented by $B$. maranhensis and was placed in Microthyriaceae and this is followed by Lumbsch and Huhndorf (2010). The ostiolate brown to black ascomata, comprising an irregular meandering arrangement of compact hyphae and irregular central ostiole are typical of Micropeltidaceae. Byssopeltis is similar to Stomiotheca in Micropeltidaceae The ascomata, asci, and ascospores in Stomiotheca amazonensis Bat. are similar to those of Byssopeltis maranhensis, albeit larger, and therefore we consider Byssopeltis to be a synonym of Stomiotheca and we transfer Byssopeltis maranhensis to the genus. 
Stomiotheca maranhensis (Bat., J.L. Bezerra \& T.T. Barros) H.X. Wu \& K.D. Hyde, comb. nov.

$\equiv$ Byssopeltis maranhensis Bat., J.L. Bezerra \& T.T. Barros, Publicações. Instituto de Micologia da Universidade de Pernambuco 636: 6 (1970)

MycoBank 563367.

Caudella Syd. \& P. Syd., Annls mycol. 14(1/2): 90 (1916).

Biotrophic on the lower surface of leaves forming small black spots. Mycelium superficial, with alternative sparse hyphopodia with haustoria penetrating the host. Thyriothecia circular, gregarious, superficial, subcarbonaceous, brown to black, lower peridium poorly developed, with a central irregular pore; in section lenticular. Upper wall comprising irregular lobed cells, tightly fitting together like a jigsaw puzzle, arranged and branching from the central pore to the outside. Peridium a single stratum, composed of black-brown cells of compact textura angularis. Hamathecium of dense, long pseudoparaphyses, anastomosing and asci inclined towards the center (Fig. 13h, j). Asci 8-spored, bitunicate, fissitunicate, cylindric-clavate, pedicellate ocular chamber indistinct, not staining blue in IKI. Ascospores overlapping 2-3-seriate, clavate, hyaline, 1-septate, cell at apex wider and shorter, lower cell long, narrow and tapering, smooth-walled.

\section{Anamorphs reported for the genus: None.}

\section{Type species}

Caudella oligotricha Syd. \& P. Syd., Annls mycol. 14(1/2): 90 (1916). Fig. 13a-p

Biotrophic on the lower surface of leaves forming small black spots (Fig. 13a, b). Mycelium superficial, with alternative sparse hyphopodia about $10 \times 5 \mu \mathrm{m}$ (Fig. 13d), with haustoria penetrating the host. Thyriothecia 38-55 $\mu \mathrm{m}$ high $\times 310-410 \mu \mathrm{m}$ diam, circular, gregarious, superficial, subcarbonaceous, brown to black, lower peridium poorly developed, with a central irregular pore; in section lenticular (Fig. 13c, e, f). Upper wall comprising irregular lobed cells, tightly fitting together like a jigsaw puzzle, arranged and branching from the central pore to the outside (Fig. 13e). Peridium 7-12 $\mu \mathrm{m}$ thick, a single stratum, composed of black-brown cells of compact textura angularis (Fig. 13g). Hamathecium of dense, long pseudoparaphyses, $1-1.5 \mu \mathrm{m}$ wide, anastomosing and asci inclined towards the center (Fig. 13h, j). Asci $80-110 \times 15-21 \mu \mathrm{m}(\bar{x}=95 \times 19 \mu \mathrm{m}, n=15), 8$-spored, bitunicate, fissitunicate, cylindric-clavate, with a $8-9.5 \times 5.5-8 \mu \mathrm{m}$ pedicel, ocular chamber indistinct, not staining blue in IKI (Fig. 13i, 1). Ascospores 30-35×5-9 $\mu \mathrm{m}(\bar{x}=32.5 \times 6.8 \mu \mathrm{m}, n=20)$, overlapping 2-3-seriate, clavate, hyaline, 1-septate, cell at apex wider and shorter, lower cell long, narrow and tapering, smooth-walled (Fig. 13k, m-p).

Anamorph: None reported.

Material examined: BRAZIL, Rio Acre, Seringal S. Francisco, on Flacourtiaceae, October 1911, E. Ule Herbarium Brasiliense No 3412 (S, F11043, holotype).

Caudella was introduced by Sydow and Sydow (1916) as a monotypic genus represented by C. oligotricha and was placed in Microthyriaceae by Müller and von Arx (1962) and this is followed by Lumbsch and Huhndorf (2010). Three other species have since been added to the genus (http://www.indexfungorum.org/Names/Names.asp).

Caudella has superficial thyriothecia comprising irregular lobed cells, tightly fitting together, arranged and branching from the central pore to the outside, with a central dehiscence irregular ostiole and superficial mycelium are present with hyphopodia. The 
genus is better accommodated into Micropeltidaceae. Caudella is similar to Stomiotheca based on the cell arrangement of ascomata and clavate ascospores with caudae. However, superficial mycelium of Stomiotheca lacking hyphopodia distinguish it from those of Caudella. It is not clear whether this separation of genera based on this single character will hold up to future molecular study.

Scolecopeltidium F. Stevens \& Manter, Bot. Gaz. 79(3): 282 (1925)

Foliar epiphytes on leaves, lacking superficial mycelium. Thyriothecia relatively large, circular, scattered, membranaceous or submembraneous, superficial, blue-green, basal peridium poorly developed, with a central rounded irregular ostiole; in section lenticular. Upper wall comprising an irregular meandering arrangement of compact hyphae. Peridium a single stratum, composed one to several layers of brown-black and compact pseudoparenchymatous cells. Hamathecium of dense, filamentous, pseudoparaphyses, embedded in mucilage, surrounding the asci inclined towards the center. Asci 8-spored, bitunicate, fissitunicate, obclavate, pedicellate, ocular chamber not observed. Ascospores fasciculate, long cylindrical to filiform, tapering towards the base, curled in the ascus.

Anamorphs reported for the genus: None.

\section{Type species}

Scolecopeltidium mirabile F. Stevens \& Manter, Bot. Gaz. 79(3): 283 (1925) Fig. 14a-k

Foliar epiphytes on the upper surface of leaves, lacking superficial mycelium. Thyriothecia 860-980 $\mu \mathrm{m}$ diam $\times 110-120 \mu \mathrm{m}$ high, relatively large, circular, scattered, membranaceous or submembraneous, superficial, blue-green, basal peridium poorly developed, with a central rounded irregular ostiole; in section lenticular (Fig. 14a-f). Upper wall comprising an irregular meandering arrangement of compact hyphae (Fig. 14c, d). Peridium 35-45 $\mu \mathrm{m}$ wide, a single stratum, composed one to several layers of brown-black and compact pseudoparenchymatous cells. Hamathecium of dense, filamentous, 1-1.5 $\mu \mathrm{m}$ wide, pseudoparaphyses, embedded in mucilage, surrounding the asci inclined towards the center (Fig. 14e, f, i). Asci 111-160×24-55 $\mu \mathrm{m}(\bar{x}=158 \times 36.5 \mu \mathrm{m}, n=15), 8$-spored, bitunicate, fissitunicate, obclavate, pedicellate, ocular chamber not observed (Fig. 14g, h). Ascospores $125-145 \times 10-12 \mu \mathrm{m}(\bar{x}=135.5 \times 11.5 \mu \mathrm{m}, n=20)$, fasciculate, long cylindrical to filiform, apex widest ( $8-9 \mu \mathrm{m})$, comprising a rounded cell, central cells oval, tapering towards the base, basal cell longer than wide, conical, hyaline, with 28-38 septa, constricted at septa, and curled in the ascus (Fig. 14j, k).

Anamorph: None reported.

Material examined: PHILIPPINES, Luzon Province, Laguna, Mt. Maquiling, on leaves of Diospyros aherni, 18 January 1931, F.L. Stevens (NY 2021).

Batista (1959) monographed this genus and included 69 species and listed the type as $S$. mirabile, which we follow here, while 83 names are listed in Index Fungorum (http://www.indexfungorum.org/names/Names.asp). We did not locate the type material but use a collection determined by F.L. Stevens. The main differences between Scolecopeltis and Scolecopeltidium are that species of the Scolecopeltidium have pseudoparaphyses (Stevens and Manter 1925). Species of Scolecopeltidium differ from Micropeltis in having filiform ascospores. It is not clear whether this separation of genera based on this single character will hold up to future molecular study; however both genera are typical of Micropeltidaceae. 


\section{Genera transferred to Microthyriales incertae cedis}

Noemicrothyrium Boonmee, H.X. Wu \& K.D. Hyde, gen. nov.

MycoBank 563368

Microthyrium microscopicum Desm. similis sed thyriothecium differt in ostiolum et pseudoparaphysicum absentae. Asci differ sin pedicel et ascosporae sin ciliatae.

Etymology: From Neo meaning new in reference to a new genus which is similar to Microthyrium.

Saprobic on the upper surface of leaves forming minute black spots. Mycelium absent. Thyriothecia circular, solitary and scattered, superficial, brown to dark brown, basal peridium poorly developed, ostiole not observed; in section lenticular. Upper wall composed of ellipsoid angular cells, arranged in parallel radiating lines from the center to the outer rim. Hamathecium of parallel asci in mucilage, inclined towards the center, pseudoparaphyses not observed. 8-spored, bitunicate, fissitunicate, globose, subglobose, clavate to ovoid, apedicellate, apically rounded with an ocular chamber, not bluing in IKI. Ascospores overlapping 2-3-seriate, obovoid to clavate, 2-celled, upper cell wider than lower cell, septum median to supramedian, hyaline, smooth-walled.

Anamorphs reported for the genus: None.

Neomicrothyrium siamense Boonmee, H.X. Wu \& K.D. Hyde, sp. nov. MycoBank 563369 Fig. $15 \mathrm{a}-\mathrm{j}$

Microthyrium microscopicum Desm. similis sed thyriothecium differt in ostiolum et pseudoparaphysicum absentae. Asci differ sin pedicel et ascosporae 7.8-10.7×3.7-5.3 $\mu \mathrm{m}$, obovoidae vel clavatae et sin ciliata.

Etymology: In reference to its occurrence in Thailand.

Saprobic on the upper surface of leaves forming minute black spots. Mycelium absent (Fig. 15a-e). Thyriothecia 100-128.5 $\mu \mathrm{m}$ diam, circular, solitary and scattered, superficial, brown to dark brown, basal peridium poorly developed, ostiole not observed; in section lenticular (Fig. 15c). Upper wall composed of ellipsoid angular cells, arranged in parallel radiating lines from the center to the outer rim (Fig. 15d). Hamathecium of parallel asci in mucilage inclined towards the center, pseudoparaphyses not observed. Asci 17.6-32.2×10.4-16.1 $\mu \mathrm{m}$ $(\bar{x}=24.5 \times 13.9 \mu \mathrm{m}, n=15), 8$-spored, bitunicate, fissitunicate, globose, subglobose, clavate to ovoid, apedicellate, apically rounded with an ocular chamber, not bluing in IKI (Fig. 15f-h). Ascospores $7.8-10.7 \times 3.7-5.3 \mu \mathrm{m}(\bar{x}=9.2 \times 4.6 \mu \mathrm{m}, n=20)$, overlapping 2 -3-seriate, obovoid to clavate, 2-celled, slightly constricted at the septum, upper cell wider than lower cell, septum median to supramedian, hyaline, smooth, surrounded by a thin mucilaginous sheath (Fig. 15i, j).

Material examined: THAILAND, Phrae Province, Song, on dead leaves of an unidentified tree, 15 January 2010, Saranyaphat Boonmee (MFLU 10-0044, holotype); extype culture BCC=IFRDCC 2194=MFLUCC 10-0112.

The introduction of a new genus is justified as the taxon differs considerably from Microthyrium in lacking a distinct ostiole, lacking pseudoparaphyses and in ascospore form. The taxon does not cluster with the three species of Asterinaceae in the phylogenetic tree (Fig. 1) and is therefore included in Microthyriales incertae cedis. 
Asterinales M.E. Barr ex D. Hawksw. \& O.E. Erikss.

The order was validated by Hawksworth and Eriksson (1986) based on an original introduction by Barr (1976), but which lacked a Latin description. The order is poorly used being recognized in Capnodiales in Index Fungorum (http://www.indexfungorum.org/Names/Names.asp), Kirk et al. (2008), MycoBank (http://www.mycobank.org/MycoTaxo.aspx) and Lumbsch and Huhndorf (2010) but has been used by Hosagoudar et al. (1996). Hoffman et al. (2010) used sequence data from five taxa of Asterina and a related anamorph stage which provided evidence for Asterinaceae as a well-supported family and sister to the Venturiaceae. Zhang et al. (2011) show Venturiaceae to comprise two families in a well supported order Venturiales which they formerly introduce. This action make it highly likely that Asterinales will also turn out to be a well-supported family and is therefore accepted in this study. The order should probably include two or three morphologically similar families, i.e. Asterinaceae, Aulographaceae and Palmulariaceae. Molecular work is needed to establish this.

\section{Genera transferred to Asterinaceae Hanfs}

This family is perhaps better understood than Microthyriaceae and has been studied by several researchers (Hofmann et al. 2010). Hansford (1946) introduced the family Asterinaceae which included 13 genera and this has subsequently been followed. Müller and von Arx (1962) included 24 genera which was increased to 27 in von Arx and Müller (1975); Kirk et al. (2008) note that there are 46 genera, while Lumbsch and Huhndorf (2010) list 38 genera. The name Asterinaceae unfortunately appears to be invalidly published (Art. 32) and should be validated in a later paper monographing the family.

Genera of Asterinaceae are biotrophic, growing superficially on living leaves and rarely stalks and shoots of higher plants in tropical and subtropical regions worldwide (Hofmann et al. 2010). They are thought to obtain nutrients by penetrating the plant with hyphopodia forming haustoria, innate nutrient mycelium, or leaf permeating hypostroma or pseudostroma (von Arx and Müller 1975; Eriksson 1981). The ascomata are thyriothecia which may be roundish, elongate or linear, with a covering comprising of radially arranged cells and open by star-like cracking, a linear fissure or slimy dehiscence. Pseudoparaphyses may be present but often deliquesce at maturity. Asci are bitunicate, semifissitunicate?, broadly clavate, obovate or saccate and usually apedicellate while ascospores and hyaline or brown, mostly two septate, with smooth or roughened walls (von Arx and Müller 1975; Eriksson 1981).

The major characters that can be used to distinguish Asterinaceae from Microthyriaceae are the thyriothecia which open by star-like cracking, a linear fissure or slimy dehiscence, whereas there is always a prominent darkened central ostiole in Microthyriaceae and asci are usually fusiform to obclavate in Microthyriaceae, while saccate in Asterinaceae. Eriksson (1981) mentions the importance of the IKI+blue, CR+minutely granular surface (= hymenial gel) on the surface of the asci, a character generally not assessed by most workers. In the present study we transfer nine genera to Asterinaceae and will provide a generic monograph of the Asterinaceae in a later paper.

Another family which is very similar to Asterinaceae is Palmulariaceae and an excellent account of the family is provided in Ignácio and Cannon (2008). These are also biotrophic plant parasitic fungi which are occasionally associated with leaf spots. The external mycelium is usually not well developed, may be fimbriate extensions, and internal mycelium may have haustoria. Ascomata may be thyriothecoid, discoid or pulvinate and the opening may be rounded, longitudinal, radial or irregular splits resulting from lysigenous splitting of the upper cell walls. The hamathecium comprises pseudoparaphyses while asci 
and ascospores are similar to those found in Asterinaceae. Ignácio and Cannon (2008) summarize the differences between Asterinaceae is Palmulariaceae and recognize the main difference as

1. Most genera of Palmulariaceae have ascomata which are immersed and often erumpent, while they are entirely superficial in most Asterinaceae.

2. Asterinaceae mostly lack pseudoparaphyses while most genera in Palmulariaceae have pseudoparaphyses.

3. Externally mycelium are well-developed in Asterinaceae while found only in a few genera in Palmulariaceae.

4. Most ascomata in Palmulariaceae which may be pulvinate are connected with a internal stroma with a central column or multiple peg-like structures which is lacking in Asterinaceae.

Ignácio and Cannon (2008) however, recognize that there is probably overlap between genera in these families and transfers may be necessary following future molecular analysis.

Asterinema Bat. \& Gayão, Anais. IV Congr. Nac. Soc. Bot. Brasil: 160 (1953).

Parasitic on the upper surface of leaves, forming roundish to irregular blackened blotches. Mycelium dark brown, reticulate, with radiating hyphae, winding, anastomosing, and branching at the margin with alternate or unilateral, capitate and one-celled hyphopodia. Thyriothecia circular, solitary or gregarious, superficial, more or less carbonaceous, black, lower peridium poorly developed, with a central irregular central ostiole; in section lenticular. Upper wall comprising irregular radially arranged lobed, crooked, brown, hyphae. Peridium comprising several layers of compressed cell, brown-black, cells. Hamathecium of asci and sparse pseudoparaphyses inclined towards the center. Asci 4-spored, bitunicate, fissitunicate, obclavate, with a short pedicel, not staining blue in IKI. Ascospores oblong to broadly ellipsoid or subclavulate, wall minutely roughened.

Anamorphs reported for the genus: Eriothyrium (Kirk et al. 2008; Hyde et al. 2011).

\section{Type species}

Asterinema caseariae Bat. \& Gayão, Anais. IV Congr. Nac. Soc. Bot. Brasil: 160 (1953). Fig. 16a-m

Parasitic on the upper surface of leaves, forming roundish to irregular blackened blotches, sometimes in aggregations, 1-8(10) $\mathrm{mm}$ in diam. Mycelium dark brown, reticulate, with radiating hyphae, winding, anastomosing, and branching at the margin and 7-9×10-12.5 $\mu \mathrm{m}$, alternate or unilateral, capitate and one-celled hyphopodia (Fig. 16e, m). Thyriothecia 230-370 $\mu \mathrm{m}$ diam $\times 20-45 \mu \mathrm{m}$ high, circular, solitary or gregarious, superficial, more or less carbonaceous, black, lower peridium poorly developed, with a central irregular ostiole up to $20 \mu \mathrm{m}$ diam; in section lenticular (Fig. 16a-d). Upper wall comprising irregular radially arranged lobed, crooked, brown, hyphae (Fig. 16b, k). Peridium 6-20 $\mu \mathrm{m}$ thick, comprising several layers of compressed cell, brown-black, $3-4 \mu \mathrm{m}$ broad cells (Fig. 16d).

Hamathecium of sparse, $1.5 \mu \mathrm{m}$ broad, long pseudoparaphyses inclined towards the center (Fig. 16f, 1). Asci 55-87×15-20 $\mu \mathrm{m}(\bar{x}=80.4 \times 19.8 \mu \mathrm{m}, n=15), 4$-spored, bitunicate, fissitunicate, obclavate, with a $7 \times 6.1 \mu \mathrm{m}$ short pedicel, not staining blue in IKI (Fig. 16g, j). Ascospores $18-23.5 \times 7-10 \mu \mathrm{m}(\bar{x}=20.4 \times 9.2 \mu \mathrm{m}, n=20)$, oblong to broadly ellipsoid or subclavulate, guttulate, slightly constricted at the septum, wall minutely roughened (Fig. $16 \mathrm{~h}, \mathrm{i})$.

Anamorph: None reported. 
Material examined: BRAZIL, on leaves of Casearia sp. (Flacourtiaceae), 30 September 1955, I. Thuma \& H.J. Maia (URM Exs. 1793, Fungos do Brasil no. 2972, holotype).

Asterinema was established as a monotypic genus and placed in the family Asterinaceae (Batista and Gayão 1953). Later, three further species and one variety were added by Batista et al. (1958) making the genus heterogeneous (Müller and von Arx 1962). Asterinema was transferred to the family Microthyriaceae by Müller and von Arx (1962) based on thyriothecia with a central ostiole. Müller and von Arx (1962) recognized this genus as comprising A. caseariae and A. glabratae Bat. \& Maia. Farr (1983) revised the genus accepting only the type species $A$. caseariae, and a newly described variety $A$. caseariae var. amazonense, which differed from the type species in having eight ascospores in the ascus and the opposite arrangement of the hyphopodia. Farr (1983) also placed this genus in Microthyriaceae. Asterinema appears to represent a distinct, taxonomically valid genus with its closest relatives in Calothyriopsis, Xenostomella, and Maublancia.

The placement of Asterinema in Microthyriaceae is unlikely because of the arrangement of cells in the thyriothecium is unlike that in Microthyrium and more like that in Asterina and the central pore is not regular but appears to form by dehiscence.

Asteritea Bat. \& R. Garnier, in Batista, Garnier, Maia \& Silva, Brotéria, sér. bot. 30(1-2): 41 (1961).

Wu et al. (2011a) suggest that Asteritea is placed into Asterinaceae because the ascomata open by star-like or longitudinal splits and lack of pseudoparaphyses.

Govindua Bat. \& H. Maia, Revta Biol., Lisb. 2: 95 (1960).

Biotrophic on the upper surface of leaves, many small ascomata gregarious and forming black spots. Mycelium superficial, without lateral hyphopodia. Thyriothecia circular, solitary or clustered in small groups, superficial, carbonaceous, black, basal peridium poorly developed, without a central ostiolar opening, rupturing at maturity to release ascospores; in section lenticular. Upper wall comprising cuboid cells, radiating from the centre and becoming larger towards the outer rim. Peridium a single substratum, composed of brown cells of compact textura angularis. Hamathecium of parallel asci in mucilage inclined towards the center, pseudoparaphyses not observed. Asci 8-spored, bitunicate, fissitunicate, globose to sub-globose or sphaerical, apedicellate, with a flat ocular chamber, ascus gel staining blue in IKI. Ascospores 1-2-seriate, broadly ellipsoidal, hyaline, two-celled, with the upper cell smaller than lower cell, with rough ornamentation, brownish with age.

Anamorphs reported for the genus: None.

\section{Type species}

Govindua shoreae Bat. \& H. Maia, Revta Biol., Lisb. 2: 95 (1960) Fig. 17a-i

Biotrophic on the upper surface of leaves, many small ascomata gregarious and forming 3-4 $\mathrm{mm}$ diam black spots. Mycelium superficial, without lateral hyphopodia. Thyriothecia 120 $220 \mu \mathrm{m}$ diam $\times 25-40 \mu \mathrm{m}$ high, circular, solitary or clustered in small groups, superficial, carbonaceous, black, basal peridium poorly developed, without a central ostiolar opening, rupturing at maturity to release ascospores; in section lenticular (Fig. 17a-f). Upper wall comprising cuboid cells, radiating from the centre and becoming larger towards the outer rim (Fig. 17c, d). Peridium 5-9 $\mu \mathrm{m}$ wide, a single substratum, composed of brown cells of compact textura angularis. Hamathecium of parallel asci in mucilage inclined towards the center, pseudoparaphyses not observed (Fig. 17e, f). Asci 55-70×40-55 $\mu \mathrm{m}(\bar{x}=60.5 \times 46 \mu \mathrm{m}$, $n=15$ ), 8 -spored, bitunicate, fissitunicate, globose to subglobose or sphaerical, apedicellate, 
with a 40-47×14.5-16 $\mu \mathrm{m}$, flat ocular chamber, ascus gel staining blue in IKI (Fig. 17g, j, k). Ascospores 30-37×18-20 $\mu \mathrm{m}(\bar{x}=33 \times 19 \mu \mathrm{m}, n=20)$, overlapping, broadly ellipsoidal, ends rounded, hyaline, two-celled, constricted at the septum, with the upper cell smaller than lower cell, with rough ornamentation, brownish with age (Fig. 17h, i).

Anamorph: None reported.

Material examined: INDIA, Mysore, Bannerghatta, on Shoreae talura, 29 July 1951, H.C. Govindu no 1471 (URM 15866, holotype).

Govindua was formally established by Batista and Maia (1960) as a monotypic genus represented by Govindua shoreae and was placed in Asterinaceae. In Lumbsch and Huhndorf (2010) the genus is placed in Microthyriaceae which follows Hawksworth et al. (1995). The superficial hyphae, lack of pseudoparaphyses, saccate asci with remnants of gel staining blue in IKI and two-celled ascospores indicate that placement in the Asterinaceae may be appropriate. Although this specimen has three numbers (URM 15866-15868), the holotype was designated as URM 15866 (Batista and Maia 1960).

Maublancia G. Arnaud, Annals d'École National d'Agric. de Montpellier, Série 2 16(1-4): 158 (1918) [1917]

Biotrophic on the upper surface of leaves appearing as indistinct black spots. Mycelium superficial, covering the leaf and ascomata, with lateral irregular hyphopodia. Thyriothecia circular, gregarious, superficial, membranaceous, brown to black, basal peridium poorly developed, opening by splitting to form a central irregular ostiole; in section lenticular. Peridium a single stratum, comprising a few layers of black-brown cells of textura prismatica. Hamathecium comprising asci embedded in mucilage inclined towards the center, pseudoparaphyses not observed. Asci 8-spored, bitunicate, fissitunicate, saccate to broadly cylindrical, apedicellate, with a distinct ocular chamber, not bluing in IKI. Ascospores overlapping uniseriate, hyaline, ovoid, 2-celled, the upper cells larger than the lower cells, smooth-walled.

\section{Anamorphs reported for the genus: none}

\section{Type species}

Maublancia myrtacearum G. Arnaud, Annals d'École National d'Agric. de Montpellier, Série 2 16(1-4): 158 (1918) [1917] Fig. 18a-o

Biotrophic on the upper surface of leaves appearing as indistinct black spots (Fig. 18a, b). Mycelium superficial, covering the leaf and ascomata, with lateral 12-17×13-16 $\mu \mathrm{m}$, irregular hyphopodia (Fig. 18d, e). Thyriothecia 320-390 $\mu \mathrm{m}$ diam $\times 36-65 \mu \mathrm{m}$ high, circular, gregarious, superficial, membranaceous, brown to black, basal peridium poorly developed, opening by splitting to form a central irregular ostiole; in section lenticular (Fig. 18b-f). Peridium 6-10 $\mu \mathrm{m}$ wide, a single stratum, comprising a few layers of black-brown cells of textura prismatica (Fig. 18f). Hamathecium comprising asci embedded in mucilage inclined towards the center, pseudoparaphyses not observed. Asci 70-110 $\times 30-34 \mu \mathrm{m}$ ( $\bar{x}=91.7-31.8 \mu \mathrm{m}, n=15), 8$-spored, bitunicate, fissitunicate, saccate to broadly cylindrical, apedicellate, with a distinct ocular chamber, not bluing in IKI (Fig. 18g, h, k). Ascospores 27-31×12-16 $\mu \mathrm{m}(\bar{x}=29.5-13.6 \mu \mathrm{m}, n=20)$, overlapping uniseriate, hyaline, ovoid, 2-celled, constricted at the septum, the upper cells larger than the lower cells, smooth-walled (Fig. $18 \mathrm{i}, \mathrm{j}, \mathrm{l}-\mathrm{o})$.

Anamorph: None reported. 
Material examined: BRAZIL, Rio de Janeiro: Ipanema, on Myrtacea cujusdam, 2 February 1913 (PC0084491, holotype).

Maublancia was established by Arnaud (1918), based on M. myrtacearum and M. juruana (Henn.) G. Arnaud and placed into Microthyriaceae (Arnaud 1918). Stevens and Ryan (1939) renamed Maublancia myrtacearum as Parasterina myrtacearum (G. Arnaud) F. Stevens and placed this genus in Asterinaceae. Müller and von Arx (1962) re-described Maublancia and placed it in Microthyriaceae and this is followed in Lumbsch and Huhndorf (2010). Maublancia myrtacearum has superficial hyphae with hyphopodia and thyriothecia opening by splitting to form a central irregular ostiole and is therefore typical of Asterinaceae. Maublancia is very similar to Asterinella (Müller and von Arx 1962) and may be a synonym, but as we have not seen the generic type material of Asterinella we leave this to a later study.

Polycyclinopsis Bat., A.F. Vital \& I.H. Lima, in Batista \& Vital, Revta Biol., Lisb. 1(3-4): 284 (1958).

Foliar epiphyte on upper surface of leaves forming black rounded spots. Mycelium superficial, not apparently penetrating host cells. Thyriothecia circular, gregarious, superficial, carbonaceous, brown-black, basal peridium poorly developed, rupturing and forming a star-shaped central pore at maturity; in section lenticular. Upper wall comprises irregularly arranged radiating cells which are branched at the outer rim, from which mycelium strands develop. Peridium comprising a single stratum, cell layers of textura prismatica, outer cells black-brown, inner cells light-brown. Hamathecium comprising asci embedded in mucilage inclined towards the center, pseudoparaphyses not observed. Asci 8spored, bitunicate, fissitunicate, subglobose, globose or saccate, apedicellate, without a distinct ocular chamber, bluing in IKI. Ascospores multi-seriate, ellipsoidal, hyaline when young, pale brown when mature, two-celled, verruculose.

\section{Anamorphs reported for the genus: None.}

\section{Type species}

Polycyclinopsis solani Bat., A.F. Vital \& I.H. Lima, in Batista \& Vital, Revta Biol., Lisb. 1(3-4): 284 (1958). Fig. 19a-1

Foliar epiphyte on upper surface of leaves, forming black rounded spots. Mycelium superficial, not apparently penetrating host cells (Fig. 19a). Thyriothecia 32-25 $\mu \mathrm{m}$ high $\times 290-430 \mu \mathrm{m}$ diam, circular, gregarious, superficial, carbonaceous, brown-black, basal peridium poorly developed, rupturing and forming a star-shaped central pore at maturity; In section lenticular. Upper wall comprises irregularly arranged radiating cells which are branched at the outer rim, from which mycelium strands develop (Fig. 19b-f). Peridium 9$17 \mu \mathrm{m}$ thick, comprising a single stratum, cell layers of textura prismatica, outer cells blackbrown, inner cells light-brown (Fig. 19f). Hamathecium comprising asci embedded in mucilage inclined towards the center, pseudoparaphyses not observed (Fig. 19e, f). Asci 33$45 \times 30-43 \mu \mathrm{m}(\bar{x}=38.6 \times 35.5 \mu \mathrm{m}, n=15), 8$-spored, bitunicate, fissitunicate, subglobose, globose or saccate, apedicellate, without a distinct ocular chamber, bluing in IKI (Fig. 19g, j). Ascospores $23-29 \times 10-14 \mu \mathrm{m}(\bar{x}=24.9 \times 12.4 \mu \mathrm{m}, n=20)$, multi-seriate, ellipsoidal, hyaline when young, pale brown when mature, two-celled, slightly constricted at the septum, verruculose (Fig. 19h, i, k).

Anamorph: None reported. 
Material examined: BRAZIL, Pernambuco, on leaf of Solanum paniculatum, 21 June 1955, A.C. Batista and A.F. Vital (URM 2471-2472 EXS: 1238, holotype).

Polycyclinopsis is a monotypic genus placed in Microthyriaceae (Batista and Vital 1958; Müller and von Arx 1962; Lumbsch and Huhndorf 2010). The genus is typical of Asterinaceae as there is no distinct ostiolar pore as in Microthyrium, but the ascomata opens by rupturing of the central upper ascomatal wall as in other genera of Asterinaceae. The bluing of asci in IKI is not distinct.

Polystomellina Bat. \& A.F. Vital, Revta Biol., Lisb. 1(3-4): 280 (1958).

Wu et al. (2011a) suggest that Polystomellina is placed in Asterinaceae which includes taxa with ascomata that are flattened and elongate, comprising radiating cells and opening with longitudinal splitting. Perhaps Aulographaceae might be suitable if it holds out to be a good family.

Resendea Bat., Brotéria, sér. Ci. Nat. 30(3-4): 87 (1961).

Foliar epiphyte on upper surface of leaves, forming crust-like, patches. Mycelium superficial, dark brown, crust-like. Thyriothecia circular, gregarious in blackened masses, superficial, carbonaceous, brown-black, basal peridium poorly developed, rupturing to form a star-like ostioles maturity. Upper wall comprising irregularly radiating, brown, hypha-like cells, which branch outwardly; in section lenticular. Peridium comprising a single stratum, comprising cells of textura prismatica. Hamathecium comprising asci embedded in mucilage inclined towards the center, pseudoparaphyses not observed. Asci 8-spored, globose or saccate, bitunicate, fissitunicate, apedicellate, without a distinct ocular chamber, not staining blue in IKI. Ascospores 2-3-seriate, ellipsoidal, hyaline when young, light brown when mature, two-celled, upper cell broader and longer than lower cell, smoothwalled.

Anamorphs reported for the genus: None.

\section{Type species}

Resendea paraguayensis Bat., Brotéria, sér. Ci. Nat. 30(3-4): 89 (1961) Fig. 20a-1

Foliar epiphyte on upper surface of leaves, forming crust-like, brown-black rounded spots (Fig. 20a). Mycelium superficial, dark brown, compact, crust-like. Thyriothecia 50-70 $\mu \mathrm{m}$ diam $\times 15-25 \mu \mathrm{m}$ high, circular, gregarious in blackened masses, superficial, carbonaceous, brown-black, basal peridium poorly developed, rupturing to form a star-like ostiole at maturity. Upper wall comprising irregularly radiating, brown, relatively thick $1.2 \mu \mathrm{m}$ walled, ellipsoidal to hypha-like cells, which branch outwardly, cells 8.3-10.8 $\mu \mathrm{m}$ long, 3.6$5.1 \mu \mathrm{m}$ wide; in section lenticular (Fig. 20b-g, k). Peridium 4-9 $\mu \mathrm{m}$ wide, comprising a single stratum, comprising cells of textura prismatica (Fig. 20e). Hamathecium comprising asci embedded in mucilage inclined towards the center, pseudoparaphyses not observed (Fig. 20i). Asci $17-25.5 \times 13-19 \mu \mathrm{m}(\bar{x}=22 \times 15.2 \mu \mathrm{m}, n=15), 8$-spored, globose or saccate, bitunicate, fissitunicate, apedicellate, without a distinct ocular chamber, not staining blue in IKI (Fig. 20i, 1). Ascospores 11-12×5-6 $\mu \mathrm{m}(\bar{x}=11.3 \times 5.5 \mu \mathrm{m}, n=20), 2-3$-seriate, ellipsoidal, hyaline when young, light brown when mature, two-celled, slightly constricted at the septum, upper cell broader and longer than lower cell, smooth-walled (Fig. 20h, j).

Anamorph: None reported.

Material examined: PARAGUAY, on leaves of Eugenia sp. (Myrtaceae), 18 January 1884, B. Balansa (URM 15859, holotype). 
Resendea was formally introduced by Batista (1961) and included R. paraguayensis, the type species and a second species $R$. crataevae Bat. Resendea was placed by Batista (1961) in the family Polystomellaceae and in Microthyriaceae by Lumbsch and Huhndorf (2010). The genus is typical of Asterinaceae as there is no distinct ostiolar pore as in Microthyrium, but the ascomata opens by rupturing of the central upper ascomatal wall as in other genera of Asterinaceae. The fungus lacks free mycelium and penetrates the host with multiple hyaline hypostroma according to Batista (1961). The taxa also needs comparing with genera of Palmulariaceae which are similar in some cases (Ignácio and Cannon 2008).

Trichopeltospora Bat. \& Cif., in Batista, Costa \& Ciferri, Publções Inst. Micol. Recife 90: 17 (1958) [1957]

Biotrophic on upper surface of leaves. Mycelium superficial, light brown, with lateral, alternate hyphopodia. Thyriothecia circular, gregarious, superficial, carbonaceous, brown to black, basal layer poorly developed, rupturing into an irregular central pore at maturity; in section lenticular. Upper wall composed of radially arranged irregular cells. Peridium comprising a single stratum of black-brown cells of closely arranged textura angularis. Hamathecium comprising asci embedded in mucilage inclined towards the center, pseudoparaphyses not observed. Asci 8-spored, bitunicate, fissitunicate, saccate or globose, apedicellate, without a distinct ocular chamber, slightly bluing in IKI. Ascospores irregularly 3-4-seriate, ellipsoidal, hyaline, becoming brown at maturity, 2-celled, slightly constricted at the septum, appearing rough-walled.

Anamorphs reported for the genus: None.

\section{Type species}

Trichopeltospora pipericola Bat., Cif. \& C.A.A. Costa, in Batista, Costa \& Ciferri, Publções Inst. Micol. Recife 90: 17 (1958) [1957] Fig. 21a-k

Biotrophic on upper surface of leaves appearing as small black spots (Fig. 21a, b). Mycelium superficial, light brown, with lateral alternate, ellipsoidal, ovate or globose, 10-9×6-6.5 $\mu \mathrm{m}$ $(\bar{x}=9.2 \times 6.3 \mu \mathrm{m}, n=$ ?) hyphopodia (Fig. $21 \mathrm{c}, \mathrm{g})$. Thyriothecia $180-390 \mu \mathrm{m}$ diam, $60-100 \mu \mathrm{m}$ high, circular, gregarious, superficial, carbonaceous, brown to black, basal layer poorly developed, rupturing into an irregular central pore at maturity; in section lenticular (Fig. 21b-f). Upper wall composed of radially arranged irregular cells. Peridium 13-26 $\mu \mathrm{m}$ thick, comprising a single stratum of black-brown cells of closely arranged textura angularis (Fig. 21f). Hamathecium comprising asci embedded in mucilage inclined towards the center, pseudoparaphyses not observed. Asci 43-60 $\mu \mathrm{m} \times 30-45 \mu \mathrm{m}(\bar{x}=51.6-40.1 \mu \mathrm{m}), 8$-spored, bitunicate, fissitunicate, saccate or globose, apedicellate, without a distinct ocular chamber, slightly bluing in IKI (Fig. 21h, i). Ascospores 26-32 $\mu \mathrm{m} \times 12-16 \mu \mathrm{m}(\bar{x}=29.3-13.7 \mu \mathrm{m})$, irregularly 3-4-seriate, ellipsoidal, hyaline, becoming brown at maturity, 2-celled, slightly constricted at the septum, appearing rough-walled (Fig. 21j, k).

Anamorph: None reported.

Material examined: BRAZIL, on Piper sp. (Piperaceae), collection time unknown, A.C. Batista (URM 2492, holotype).

Trichopeltospora was established by Batista et al. (1957) as a monotypic genus. T. pipericola var. elongata and $T$. pipericola var. minospora Bat. \& Peres and T. reticulata have since been added to the genus (Batista et al. 1957; Bezerra and Cavalcante 1967). The genus is typical of Asterinaceae as there is no distinct ostiolar pore as in Microthyrium, but the ascomata opens by rupturing of the central upper ascomatal wall as in other genera of 
Asterinaceae. The bluing of the mucilage remnants on the asci in IKI is not distinct and it is not clear if this is an important character of Asterinaceae. This is very similar to Polycyclinopsis (see above), however the arrangement of cells in the upper wall differ.

Xenostomella Syd., Annls mycol. 28(1/2): 130 (1930).

Plochmothea Syd., Annls mycol. 37(4/5): 395 (1939)

Biotrophic on upper surface of leaves. Mycelium superficial, light brown, anastomosing, and sparsely septate, with hyphopodia from which hyaline, multicellular haustoria penetrate the epidermis of the leaf. Thyriothecia circular, gregarious, superficial, carbonaceous, brown to black, basal peridium poorly developed, with a central irregular dissolving ostiole; In section lenticular. Upper wall composed of irregularly interwoven cells. Peridium comprising a single stratum of 4-5 layers of brown cells of textura angularis. Hamathecium comprising asci embedded in mucilage inclined towards the center, pseudoparaphyses sparse and only apparent in section (Fig. 22g). Asci 8-spored, bitunicate, fissitunicate, obclavate or broadly fusiform, with short pedicel, ocular chamber not apparent, not bluing in IKI. Ascospores overlapping 3-4-seriate, hyaline, becoming brown at maturity, 2-celled, clavate to fusiform, upper cells wider than lower cell, lower cells tapering to rounded base, wall smooth.

Anamorphs reported for the genus: None.

\section{Type species}

Xenostomella tovarensis Syd., Annls mycol. 28(1/2): 130 (1930). Fig. 22a-m

Biotrophic on upper surface of leaves causing brown-black spots. Mycelium superficial, hyphae pigmented, light brown, anastomosing, and sparsely septate, with lateral alternate, ellipsoidal, ovate or globose, 11.5-7×6-9.5 $\mu \mathrm{m}(\bar{x}=8.7-7.3 \mu \mathrm{m}, n=10)$, light brown hyphopodia from which hyaline, multicellular haustoria penetrate the epidermis of the leaf (Fig. 22d, f). Thyriothecia 220-440 $\mu \mathrm{m}$ diam, 50-75 $\mu \mathrm{m}$ high, circular, gregarious, superficial, carbonaceous, brown to black, basal layer poorly developed, with a dissolving central ostiole; in section lenticular (Fig. 22a-c, e, g). Upper wall composed of irregularly interwoven cells (Fig. 22c). Peridium 6-8 $\mu \mathrm{m}$ thick, brown, comprising a single stratum, comprising 4-5 layers of cells of textura angularis (Fig. 22h). Hamathecium comprising asci embedded in mucilage inclined towards the center, pseudoparaphyses sparse and only apparent in section (Fig. 22g). Asci 35-81 $\mu \mathrm{m} \times 23-32.5 \mu \mathrm{m}(\bar{x}=59.4 \times 27 \mu \mathrm{m}, n=20), 8$ spored, bitunicate, fissitunicate, obclavate or broadly fusiform, with short pedicel, ocular chamber not apparent, not bluing in IKI (Fig. 22i, 1, m). Ascospores 16.5-21 $\mu \mathrm{m} \times 6-9 \mu \mathrm{m}$ $(\bar{x}=18.5 \times 7.2 \mu \mathrm{m}, n=25)$, overlapping 3-4-seriate, hyaline, becoming brown at maturity, 2 celled, slightly constricted at the septum, clavate to fusiform, upper cells wider than lower cell, lower cells tapering to rounded base, wall smooth (Fig. 22j, k).

Anamorph: None reported.

Material examined: VENEZUELA, Colonia Tovar, Aragua, in leaves of Lycianthis xylopiifoliae (Solanaceae), 19 January 1928, H. Sydow, Sydow, Fungi exotici exsiccati (S 843, holotype).

Xenostomella was established by Sydow (1930) as a monotypic genus and X. meridensis Toro (Chardón and Toro 1934) and X. monninae (Müller and von Arx 1962) have since been added to the genus. Müller and von Arx (1962) place the genus in the Microthyriaceae due to ostiole in the thyriothecium, the cylindrical asci and the 2-celled ascospores and this is followed by Kirk et al. (2008) and Lumbsch and Huhndorf (2010). Xenostomella is closely related to Maublancia based on the superficial hyphae present and haustoria although it is 
not clear if these structure are taxonomically important. Ascomata of Maublancia are however, mostly discrete, and ascospores are wider than $8 \mu \mathrm{m}$ and are readily distinguishable from those of Xenostomella. The ostiole in Xenostomella is not distinct and appears to dissolve to form an opening, while the arrangement of cells in the peridium differs to that in Microthyrium in being an irregular arrangement and are more typical of Asterinaceae. We suggest that this genus is included in Asterinaceae. Fresh collections are needed for molecular analysis.

\section{Genera transferred to Aulographaceae Luttr. ex P.M. Kirk, P.F. Cannon \& J.C. David}

The family Aulographaceae was first invalidly proposed by Luttrell (1973) and formerly introduced by Kirk et al. (2001) and is characterized by brown often inconspicuous superficial mycelium which lack hyphopodia and flattened elongate ascomata opening by slit (Luttrell 1973; Kirk et al. 2008). The upper wall comprises parallel radiating lines of ellipsoid cells from the central ostiole to the outer rim, pseudoparaphyses are absent and asci are bitunicate, fissitunicate, clavate to broadly cylindrical and ascospores are hyaline with 1 septate. Species are usually saprobic on dead plant material and the anamorphs are unknown (Kirk et al. 2008). Genera included are Aulographum and Polyclypeolina.

Müller and von Arx (1962) treated Aulographum in Asterinaceae and in many ways this treatment appears to be well judged. Major differences would be lack of hyphopodia, opening by a slit rather than star-like cracking or slimy dehiscence and clavate as compared to saccate asci and it is not clear if these differences would stand up to phylogenetic analysis. Eriksson (1981) also points out that the asci of Aulographaceae are IKI- unlike the IKI+asci of Asterinaceae. Fresh collections are needed to establish if this family holds up to molecular analysis.

Aulographum Lib., Pl. crypt. Arduenna, fasc. (Liège) 3: no. 272 (1834)

Saprobic on leaves. Mycelium superficial, sparse. Thyriothecia globose to ellipsoidal, simple or branched, scattered to loosely clustered, superficial, membraneous, black, basal peridium poorly developed, opening by an irregular slit, in section lenticular. Upper wall comprising parallel radiating lines of ellipsoid cells from the central ostiole to the outer rim. Peridium a single stratum composed of black-brown pseudoparenchymatous cells of compact textura angularis. Hamathecium of sparse, asci embedded in mucilage inclined towards the center, pseudoparaphyses not observed. Asci 8-spored, bitunicate, fissitunicate, globose to subglobose, without pedicel. Ascospores hyaline, 1-septate, the upper cell often broader than the lower cell, smooth-walled.

Anamorphs reported for the genus: None.

\section{Type species}

Aulographum hederae Lib., Pl. crypt. Arduenna, fasc. (Liège) 3: no. 272 (1834) Fig. 23a-j

三Aulographum vagum Desm., Annls Sci. Nat., Bot., sér. 2 19: 362 (1843)

Saprobic on leaves. Mycelium superficial, sparse. Thyriothecia 85.5-135.8 $\mu \mathrm{m}$ diam, (200-) 221-300 long, globose to ellipsoidal, simple or branched, scattered to loosely clustered, superficial, membraneous, black, basal peridium poorly developed, opening by an irregular slit, in section lenticular (Fig. 23a-c). Upper wall comprising parallel radiating lines of ellipsoid cells from the central ostiole to the outer rim. Peridium a single stratum composed of black-brown pseudoparenchymatous cells of compact textura angularis. Hamathecium of sparse asci embedded in mucilage inclined towards the center, pseudo-paraphyses not 
observed. Asci (20-) 25-35×(10-) 15-17.5 $\mu \mathrm{m}(\bar{x}=29 \times 20 \mu \mathrm{m}, n=15,8$-spored, bitunicate, fissitunicate, globose to subglobose, without pedicel (Fig. 23e-h). Ascospores (10-) 15$17 \times 2.5 \mu \mathrm{m}(\bar{x}=15 \times 2.5 \mu \mathrm{m}, n=20)$, overlapping 2-4-seriate, narrowly obovoid to narrowly clavate, hyaline, 1-septate, slightly constricted at the septum, the upper cell often broader than the lower cell, smooth-walled, with remnants of mucilage (Fig. 23i-j).

Anamorph: None reported.

Material examined: BELGIUM, on dry leaves of Crataegus glaber and Ilex aquifolium, sample no. 5020103861716 (BR, specimen of A. vagum).

Aulographum has received various treatments and was previously treated as Hysteriaceae, Microthyriaceae, Leptopeltidaceae, Asterinaceae and Aulographaceae (Eriksson 1981; Lumbsch and Huhndorf 2010). One of the latter two families seems most appropriate and here we refer the genus to Aulographaceae because the asci lack IKI+remnants and thyriothecia open by a longitudinal slit. The genus has 75 names (http://www.indexfungorum.org/names/Names.asp) or an estimated 30 species (Kirk et al. 2008) and has not been studied recently.

Cirsosina Bat. \& J.L. Bezerra, Revta Biol., Lisb. 2(2): 132 (1960).

Wu et al. (2011a) placed genus this in Aulographaceae based on the superficial hyphae without hyphopodia and slit-like opening. Here we find an earlier genus to accommodate it in Lembosiella.

Lembosiella Sacc., Syll. fung. (Abellini) 9: 1101 (1891).

Cirsosina Bat. \& J.L. Bezerra, Revta Biol., Lisb. 2(2): 132 (1960).

Foliar epiphyte on the upper surface of leaves, superficial mycelium present, sparse, hyphopodia absent. Thyriothecia globose, ellipsoidal, or cylindrical, gregarious or some solitary, superficial, membranaceous, black-brown, lacking a well-developed basal peridium, opening by a longitudinal split, easily separated from the host; in section lenticular. Upper wall comprising parallel radiating lines of ellipsoid cells from the central ostiole to the outer rim. Peridium a single stratum composed of black-brown pseudoparenchymatous cells of compact textura angularis. Hamathecium of sparse asci, embedded in mucilage inclined towards the center, pseudoparaphyses not observed. Asci 8spored, bitunicate, fissitunicate, spherical, broadly oblong, sessile. Ascospores rounded at the ends, brown when mature, two-celled, with the upper cell wider than lower cell, smooth walled.

Anamorphs reported for the genus: none.

\section{Type species}

Lembosiella polyspora (Pat.) Sacc., Syll. fung. (Abellini) 9: 1101 (1891)

$\equiv$ Lembosia polyspora Pat. 1887 Fig. 24a-1

Foliar epiphyte on the upper surface of leaves, superficial mycelium present, sparse, hyphopodia absent. Thyriothecia 275-320 $\mu \mathrm{m}$ long $\times 130-190 \mu \mathrm{m}$ wide and about 35-50 $\mu \mathrm{m}$ high, globose, ellipsoidal, or cylindrical, gregarious or some solitary, superficial, membranaceous, black-brown, lacking a well-developed basal peridium, opening by a longitudinal split, easily separated from the host; in section lenticular. Upper wall comprising parallel radiating lines of ellipsoid cells from the central ostiole to the outer rim (Fig. 24a, b, c, d). Peridium 5-10 $\mu$ m wide, a single stratum composed of black-brown 
pseudoparenchymatous cells of compact textura angularis. Hamathecium of sparse asci, embedded in mucilage inclined towards the center, pseudoparaphyses not observed (Fig. 24e). Asci $30-42 \times 11-26 \mu \mathrm{m}(\bar{x}=40.6 \times 21.5 \mu \mathrm{m}, n=15), 8$-spored, bitunicate, fissitunicate, spherical, broadly oblong, sessile (Fig. $24 \mathrm{f}-\mathrm{h})$. Ascospores $16-21 \times 6-9.5 \mu \mathrm{m}(\bar{x}=18.3 \times 7.9$ $\mu \mathrm{m}, n=20$ ), rounded at the ends, at first hyaline and then brown when mature, two-celled, slightly constricted at septa with the upper cell wider than lower cell, guttulate, smooth walled (Fig. 24i-1).

Anamorph: None reported.

Material examined: CONGO, on leaves of Cujusdam (Ochnaceae), date unknown (PC 0084466, holotype).

Lembosiella was formally established by Saccardo (1891) with L. polyspora as the type species based on the basionym Lembosia polyspora Pat. and placed in the family Asterinaceae. Lembosiella is similar to Lembosia in Asterinaceae, the latter being distinguished by superficial hyphae with intercalary or lateral hyphopodia (von Arx and Müller 1975). Lumbsch and Huhndorf (2010) place Lembosiella in Microthyriaceae. Lembosiella polyspora has superficial hyphae lacking hyphopodia and elongate ascomata opening by a longitudinal split, spherical bitunicate asci, and two-celled light brown mature ascospores. These characters are atypical of Microthyriaceae and we suggest that Lembosiella is placed into Aulographaceae.

\section{Genera transferred to Trichothyriaceae Theiss}

Trichothyriaceae was introduced by Theissen (1914) and maintained as a distinct family by Hughes (1953), Müller and von Arx (1962), von Arx and Müller (1975) and Eriksson (1981). Hawksworth et al. (1983), however, included Trichothyriaceae under Microthyriaceae and this was supported by Eriksson (1984) and has been subsequently followed (Lumbsch and Huhndorf 2010). The genera of Trichothyriaceae are parasitic on ascomycetes (Meliolaceae and Diatrypaceae) and lichens and the mycelium develop on the parasitized fungus and form thalli. Thyriothecia are superficial, occur on stalked cells or hyphae, flattened, discoid or lenticular and circular with a central ostiolar pore and comprising radiating rows of brownish cells. The peridium is well-developed above and below and in this sense differ from Asterinaceae, Micropeltidaceae, Microthyriaceae and other thryriothecial families. Asci are arranged at the periphery and converge towards the central pore and are 8-spored, bitunicate, fissitunicate, obclavate, apedicellate and without a distinct ocular chamber. Ascospores are small, hyaline or light brown and 1-septate and may have ciliate appendages.

Trichothyriaceae has been used to accommodate several genera now placed in Microthyriaceae. Spooner and Kirk (1990) have stated that "any attempt to rationalize the taxonomy of Trichothyriaceae (and this also applies to Microthyriaceae) based solely on morphology is likely to prove unsatisfactory and will lead to both artificial segregation of closely related species and to the inclusion of unrelated species in the same genus". This is because the group has too few morphological characters to bear any significance on the classification. The genera thus need recollecting, epitypifying and sequencing to establish their taxonomic affinities.

Von Arx and Müller (1975) included four genera (Actinopeltis Höhn., Trichothyrina (Petr.) Petr., Trichothyrinula Petr. and Trichothyrium Speg.) in Trichothyriaceae and in this study we confirm the similarity of these genera which are distinct from Microthyriaceae in being parasitic on other fungi and in ascomatal form as there is a well-developed basal peridium. 
We also include Lichenopeltella which is parasitic on lichens and an earlier name for Trichothyrina, and Trichothyriomyces which is parasitic on in other fungi Meliolaceae.

Another genus forming similar cellular hypostroma with lobed thalli is Brefeldiella in Brefeldiellaceae. The extensively developed thallus which is made up of radially arranged cells and covers the ascomata locule are intermediate between Microthyriaceae and Trichothyriaceae. The asci and ascospores are however, quite similar (von Arx and Müller 1975; Spooner and Kirk 1990).

Trichothyrium Speg., Boln Acad. nac. Cienc. Córdoba 11(4): 555 (1889)

Actinopeltella Doidge, Bothalia 1(4): 216 (1924)

Actinopeltis Höhn., Denkschriften. Kaiserlichen. Akademie. Wissenschaften., Math.Naturwiss. Kl. 83: 17 (1907)

Actinosoma Syd., Annls mycol. 28(1/2): 153 (1930)

Asteridiellina Seaver \& Toro, in Seaver \& Chardon, Scient. Surv. P. Rico 8: 25 (1926)

Caenothyrium Theiss. \& Syd., Annls mycol. 15(6): 417 (1918) [1917]

Chaetothyriopsis F. Stevens \& Dorman, in Stevens, Mycologia 19(5): 237 (1927)

Dasypyrena Speg., Anal. Mus. nac. Hist. nat. B. Aires 23: 109 (1912)

Halbaniella Theiss., Annls mycol. 14(6): 430 (1917) [1916]

Loranthomyces Höhn., Sber. Akad. Wiss. Wien, Math.-naturw. Kl., Abt. 1 118: 840 [28 repr.] (1909)

Mycolangloisia G. Arnaud, Annals d'École National d'Agric. de Montpellier, Série 2 16(1-4): 157 (1918) [1917]

Trichopeltis Speg., Boln Acad. nac. Cienc. Córdoba 11: 571 (1889)

Trichopeltopsis Höhn., Sber. Akad. Wiss. Wien, Math.-naturw. Kl., Abt. 1 118: 861 [49 repr.] (1909)

Trichopeltula Theiss., Zentbl. Bakt. ParasitKde, Abt. II 39: 636 (1914)

Trichothyriopsis Theiss., Beih. bot. Cbl. 32(2): 4 (1914)

Trotteria Sacc., Atti Inst. Veneto Sci. lett., ed Arti 10: 79 (1919)

Hyperparasitic on other fungi on the upper surface of host leaves. Mycelium superficial with hyphopodia, forming lobed thalli. Thyriothecia solitary or gregarious, circular, superficial, membranaceous, brown to dark brown, basal peridium well developed, with a central ostiole; in section lenticular. Upper wall comprising rows of radiating cells which form parallel lines from the central ostiole to the outer rim. Hamathecium of asci arranged from the periphery towards the central ostiole and sparse pseudoparaphyses. Asci 8-spored, bitunicate, fissitunicate, obclavate, apedicellate. Ascospores obclavate, hyaline, two-celled, smooth-walled.

\section{Anamorphs reported for the genus: None.}

Type species: Trichothyrium sarciniferum Speg., Boln Acad. nac. Cienc. Córdoba 11(4): 556 (1889).

It was not possible to loan this specimen from LPS during the time frame of this study, however T. reptans (Berk. \& M.A. Curtis) S. Hughes has been well illustrated by Müller and 
von Arx (1962) and von Arx and Müller (1975). An image of the herbarium package of $T$. sarciniferum is available at http://www.cybertruffle.org.uk/spegazzini/eng/001441a_htm and shows the circular thyriothecia with a central ostiole, an upper wall of neatly arranged parallel cells, superficial hyphae forming lobed thalli, obclavate bitunicate asci, obclavate asci and an Isthmospora anamorph. Hughes (1953) gave the earlier name for T. sarciniferum as T. asterophorum and this is written by Spegazzini on the herbarium package as “Trichothyrium sp. (n.gen.) sarciniferum sp. or Micropeltis? asterophora B. \& Br. c.f.?"A detailed account of $T$. asterophorum and two other species plus a discussion of the genus and the anamorph is provided by Hughes (1953). Eriksson (1981) also illustrate $T$.

asterophorum and provide SEM micrographs of the thyriothecia.

Actinopeltis peristomalis and Trichothyriopsis densa which are generic types are analogous to Trichothyrium and are redescribed, combined and illustrated here. Since this genus has numerous synonyms and species it needs to be monographed and fresh collections are required for sequence analysis and family placement.

Trichothyrium peristomalis (Höhn.) H.X. Wu \& K.D. Hyde, comb. nov.

$\equiv$ Actinopeltis peristomalis Höhn., Denkschr. Kaiserl. Akad. Wiss., Math.-Naturwiss. K1. 83: 17 [extr.] (1907) Fig. 25a-n

MycoBank 563438

Hyperparasitic on other fungi on the upper surface of leaves, not causing leaf spots (Fig. 25a). Superficial mycelium black, with $23-15 \times 10-13 \mu \mathrm{m}$ hyphopodia, forming lobed thalli (Fig. 251). Thyriothecia 30-65 $\mu \mathrm{m}$ high $\times 110-130 \mu \mathrm{m}$ diam, circular, solitary or gregarious, superficial, membranaceous, brown to black, basal layer well developed, with a depressed ostiole in the centre which is 8.9-12 $\mu \mathrm{m}$ diam; in section lenticular. Upper wall composed of 2.8-3.1 $\mu \mathrm{m}$ wide ellipsoid cells which form parallel radiating lines from the central ostiole to the outer rim (Fig. 25b, c, d). Peridium 7-20 $\mu \mathrm{m}$ thick, one-layered, composed of brown pseudoparenchymatous cells of textura angularis (Fig. 25e). Hamathecium of sparse, 2.1$3.9 \mu \mathrm{m}$ broad pseudoparaphyses, which are longer than and surround asci (Fig. 25h, k). Asci $35-55 \times 15-26 \mu \mathrm{m}(\bar{x}=45.7 \times 17.2 \mu \mathrm{m}, n=15), 8$-spored, bitunicate, fissitunicate, obclavate, apedicellate, ocular chamber not observed (Fig. 25f, i, j, m). Ascospores 14.5-17.5 $\times 5-7.5$ $\mu \mathrm{m}(\bar{x}=16.5 \times 5.8 \mu \mathrm{m}, n=20), 2-3$-seriate, obclavate, hyaline, two-celled, lower cells longer than upper cells, slightly constricted at the septum, with guttulate ornamentation (Fig. 25g, n).

Anamorph: None reported.

Material examined: BRAZIL, Santos, Raiz da Serra; on other fungi of pinna of unidentified sp., 4 June 1901, V. Schiffner (FH 258807 holotype, K (M) 158701, isotype).

Actinopeltis is a well-established genus which is widely distributed in Africa, Europe and South America (Kirk et al. 2008). The genus was formally established by Höhnel (1907) based on superficial thyriothecium, with radiating cells and phragmoseptate ascospores and placed in Microthyriaceae and as a monotypic genus represented by Actinopeltis

peristomalis. Subsequently, a few authors have studied Actinopeltis and added or transferred species (Müller and von Arx 1962; Ellis 1977; Spooner and Kirk 1990) and there 14 records in the genus. Ellis (1977) described and illustrated a new species from Britain. Ellis (1977) pointed out that Actinopeltis resembles Trichothyrina (current name: Lichenopeltella), but has phragmoseptate ascospores and setae around the ostiole. Ellis (1977) considered the setae around the ostiole to be a character of generic significance. Our re-examination of the type species indicate that setae do not occur around the ostiolar collar in A. peristomalis and that ascospores are one-septate. 
Although we have not seen Trichothyrium reptans the account of this species in Müller and von Arx (1962) is identical to that of Actinopeltis peristomalis and therefore the latter genus and the species must be considered a synonym. The type species of Trichothyrium is $T$. asterophorum (= T. sarciniferum Speg.).

Trichothyrium densum Racib., Bull. int. Acad. Sci. Lett. Cracovie, Cl. sci. math. nat. Sér. B, sci. nat. 3: 380 (1909)

$$
\equiv \text { Trichothyriopsis densa (Racib.) Theiss., Beih. bot. Cbl. 32(2): } 4 \text { (1914) }
$$

MycoBank 563440 Fig. 26a-o

Hyperparasitic on other fungi on the upper surface of leaves, not causing leaf spots.

Superficial mycelium black, with hyphopodia and forming lobed thalli (Fig. 26d).

Thyriothecia 30-40 $\mu \mathrm{m}$ high $\times 90-140 \mu \mathrm{m}$ diam, circular, gregarious, superficial, submembranaceous, slightly carbonaceous, reddish-brown, basal peridium developed, with a central ostiole; in section lenticular (Fig. 26a-c, e, f). Upper wall composed of cuboids cells which form parallel radiating lines from the central ostiole to the outer rim (Fig. 26b, c). Peridium 5-15 $\mu \mathrm{m}$ wide, a single stratum, composed of brown-black pseudoparenchymatous cells of compact textura angularis. Hamathecium of asci arranged at the periphery and sparse pseudoparaphyses, embedded in mucilage (Fig. 26f, h). Asci 27-49×14-16.5 $\mu \mathrm{m}$ $(\bar{x}=40.2 \times 14.9 \mu \mathrm{m}, n=15), 8$-spored, bitunicate, fissitunicate, obclavate, with a short pedicel 5 $\mu \mathrm{m}$ wide $\times 4 \mu \mathrm{m}$ long, ocular chamber not apparent (Fig. 26g, i). Ascospores 15-17×5-6 $\mu \mathrm{m}$ $(\bar{x}=16 \times 5.1 \mu \mathrm{m}, n=20)$, overlapping $2-3$-seriate, clavate, hyaline to pale coloured, two-celled, slightly constricted at septum, upper cell wider and shorter than lower cell, guttulate, wall smooth (Fig. 26j-o).

Anamorph: None reported.

Material examined: INDONESIA, on other fungi, date of collection unknown, Raciborski (KRA-F 0-2129(J), holotype).

Trichothyriopsis was formally established by Theissen (1914a) with Trichothyriopsis densa as the type species. Müller and von Arx (1962) had synonymised this under Trichothyrium reptans (Berk. \& M.A. Curtis) S. Hughes. We agree that this taxon is a species of Trichothyrium. The species is however, different from T. reptans in ascospore size and therefore we retain Trichothyrium densum as a distinct species.

Lichenopeltella Höhn., Sber. Akad. Wiss. Wien, Math.-naturw. Kl., Abt. 1 128: 553 (1919)

Didymopyrostroma Bat. \& Cavalc., Anais XIII Congr. Soc. bot. Brasil: 473 (1964) [1962]

Micropeltopsis Vain., Acta Soc. Fauna Flora fenn. 49 (no. 2): 218, 262 (1921)

Microthyris Clem., in Clements \& Shear, Gen. fung., Edn 2 (Minneapolis): 98, 302 (1931)

Trichothyrina (Petr.) Petr., Sydowia 4(1-6): 167 (1950)

Hyperparasitic on lichens, forming black spots. Thyriothecia circular, coniform or subglobose, numerous, gregarious, superficial, black, basal peridium well developed, with a central ostiole; in section lenticular, hyphae penetrating lichen. Upper wall composed of cuboids cells which form parallel radiating lines from the central ostiole to the outer rim. Peridium a single stratum comprising several layers of compressed cells. Hamathecium of asci arranged at the periphery, pseudoparaphyses not observed or lacking. Asci 8-spored, 
bitunicate, fissitunicate, obclavate, with a short rounded pedicel. Ascospores 2-3-seriate, hyaline, ellipsoid, 2-celled.

Anamorphs reported for the genus: None.

\section{Type species}

Lichenopeltella maculans (Zopf) Höhn. Sber. Akad. Wiss. Wien, Math.-naturw. Kl., Abt. 1 128(7-8): 553 (1919) Fig. 27a-g

$\equiv$ Microthyrium maculans Zopf, Nova Acta Acad. Caes. Leop.-Carol. German. Nat. Cur. 4: 258 (1898)

Hyperparasitic on lichens, forming black spots. Thyriothecia 60-170 $\mu \mathrm{m}$ diam, 35-60 $\mu \mathrm{m}$ high, circular, coniform or subglobose, numerous, gregarious, superficial, 1-2 loculate, membranaceous or slightly carbonaceous, black, basal peridium well developed, with a central ostiole; in section lenticular, hyphae penetrating lichen (Fig. 27a-c). Upper wall composed of cuboids cells which form parallel radiating lines from the central ostiole to the outer rim (Fig. 27b). Peridium $8-13 \mu \mathrm{m}$ wide, a single stratum comprising several layers of compressed cells (Fig. 27c). Hamathecium of asci arranged at the periphery, pseudoparaphyses not observed or lacking (Fig. 27d). Asci 47-65×10-14 $\mu \mathrm{m}, 8$-spored, bitunicate, fissitunicate, obclavate, with a short rounded pedicel, apical structure

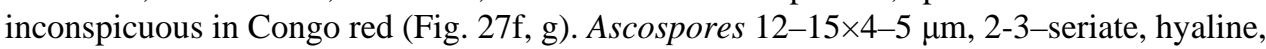
ellipsoid, 2-celled, slightly constricted at the septum, 1-2 guttulate when mature, smoothwalled (Fig. 27e).

Anamorph: None reported.

Material examined: GERMANY, Harz, Rosstrappe, on thallus of Gyroohora hirsuta, September 1897, F.W. Zopf. 1742 (K 158704 isotype).

Lichenopeltella was established by Höhnel (1919) as a monotypic genus with L. maculans as the type species and there are now 44 epithets

(http://www.indexfungorum.org/names/Names.asp), while Kirk et al. (2008) estimate that there are some 20 species. The genus has been reasonably well studied (Hawksworth and Santesson 1990; Spooner and Kirk 1990; Krishnamurthy and Hariharan 1996), but its biology is poorly known. Müller and von Arx (1962) and von Arx and Müller (1975) place Lichenopeltella in the Leptopeltidaceae, and this is followed in Kirk et al. (2008) who accept Leptopeltidaceae as one of three families in Microthyriales. However this is not followed in the more recent classifications in Lumbsch and Huhndorf (2010). Although the cells in the thyriothecium in L. maculans are neatly arranged in a parallel fashion from the central ostiole as in Microthyriaceae several other characters indicate that Lichenopeltella probably belongs in another family. This includes the basal peridium which is well developed and the lichenicolous habit. The family Leptopeltidaceae may be suitable, although the species Leptopeltis aquilina (Fr.) Petr. illustrated by Müller and von Arx (1962) is asterinaceous. We place Lichenopeltella in Trichothyriaceae. Fresh collections and sequence data are needed to establish its relationships with other Dothideomycetes.

Macrographa Etayo, in Etayo \& Sancho, Biblthca Lichenol. 98: 116 (2008)

Macrographa antarctica Etayo, in Etayo \& Sancho, Biblthca Lichenol. 98: 116 (2008)

This genus was introduced for a species occurring on lichens in Chile and was compared with Lichenopeltella (Etayo and Sancho 2008). The ascostromata are multi-loculate and 
ascospores ellipsoidal-fusiform and one septate. This taxon belongs in Trichothyriaceae but whether it is distinct from Lichenopeltella needs to be established.

Pachythyrium G. Arnaud ex Spooner \& P.M. Kirk, Mycol. Res. 94(2): 228 (1990)

Pachythyrium parasiticum (Fabre) G. Arnaud ex Spooner \& P.M. Kirk, Mycol. Res. 94(2): 228 (1990)

三 Bertia parasitica Fabre, Annls Sci. Nat., Bot., sér. 6 9: 95 (1879) [1878]

$\equiv$ Berlesiella parasitica (Fabre) Höhn., Sber. Akad. Wiss. Wien, Math.-naturw. K1., Abt. 1 124: 60 (1920)

$\equiv$ Homostegia parasitica (Fabre) Rehm

इ Pachythyrium parasiticum (Fabre) G. Arnaud, Bull. trimest. Soc. mycol. Fr. 69: 302 (1954) [1953]

三 Psilosphaeria parasitica (Fabre) Cooke, Grevillea 16 (no. 78): 51 (1887)

$\equiv$ Trichothyrina parasitica (Fabre) Arx, in Müller \& von Arx, Beitr. Kryptfl. Schweiz 11(no. 2): 559 (1962)

We have been unable to locate the type material of this species. It is a parasite on Diatrypaceae. This species and thus the genus is considered a synonym of Trichothyrina parasitica by Müller and von Arx (1962). Spooner and Kirk (1990) however, thought this was a distinct genus and thus validated it. A collection from the UK was examined by Ellis (1977) and is described and illustrated. The thyriothecia are not typical of Microthyrium and therefore placement in Trichothyriaceae may be warranted.

Trichothyriomyces Bat. \& H. Maia, in Batista, Maia, Silva \& Vital, Anais Soc. Biol. Pernambuco 13(2): 104 (1955).

Hyperparasitic on fungi, forming black spots on fungi on the lower surface on leaves. Mycelium superficial, hyphae forming thalli. Thyriothecia gregarious, circular, solitary or clustered, superficial, subcarbonaceous, brown to black, basal peridium relatively welldeveloped, with a central rounded ostiole, in section lenticular. Upper wall composed of cuboids cells which form parallel radiating lines from the central ostiole to the outer rim. Peridium comprising closely packed cells of textura angularis. Hamathecium comprising asci immersed in mucilage, pseudoparaphyses not observed or lacking. Asci, 8-spored, bitunicate, fissitunicate, saccate or obovate, apedicellate. Ascospores overlapping 4-5seriate, hyaline, 2-celled.

Anamorphs reported for the genus: None.

\section{Type species}

Trichothyriomyces notatus Bat. \& H. Maia, in Batista, Maia, Silva \& Vital, Anais Soc. Biol. Pernambuco 13(2): 104 (1955) Fig. 28a-1

三 Trichothyrium notatum (Bat. \& H. Maia) Arx, in Müller \& Arx, Beitr. Kryptfl. Schweiz 11(no. 2): 557 (1962).

Hyperparasitic on fungi, forming black spots on fungi on the lower surface on leaves (Fig. 28a, b). Mycelium superficial, hyphae forming thalli (Fig. 28d). Thyriothecia 230-320 $\mu \mathrm{m}$ diam, 20-40 $\mu \mathrm{m}$ high, gregarious, circular, solitary or clustered, superficial, subcarbonaceous, brown to black, basal peridium relatively well-developed, with a central rounded ostiole, in section lenticular (Fig. 28b, c, e-g). Upper wall composed of cuboids cells which form parallel radiating lines from the central ostiole to the outer rim (Fig. 28h). 
Peridium 5-10 $\mu \mathrm{m}$ wide, brown-black, comprising a single stratum of closely packed cells of textura angularis (Fig. 28e, f). Hamathecium comprising asci immersed in mucilage, pseudoparaphyses not observed or lacking. Asci 26-40×14-21 $\mu \mathrm{m}(\bar{x}=31.3-16.7 \mu \mathrm{m}, n=15)$, 8 -spored, bitunicate, fissitunicate, saccate or obovate, apedicellate (Fig. 28i, 1). Ascospores 5-8×2.5-4 $\mu \mathrm{m}(\bar{x}=6.5-3.1 \mu \mathrm{m}, n=20)$, overlapping 4-5-seriate, hyaline, ellipsoidal, 2-celled, slightly constricted at the septum, smooth-walled (Fig. 28j, k).

Anamorph: None reported.

Material examined: BRAZIL, on Meliola melastomacearum Speg. (as Irene melastomacearum), 1955, A.C. Batista (URM 2962-2963, holotype).

Trichothyriomyces was established by Batista et al. (1955) as a monotypic genus represented by T. notatus and placed in Trichothyriaceae. This genus is parasitic on other fungi, forming small spots on leaves, has superficial hyphae forming thalli, and thyriothecia composed of radiating cells and bitunicate asci with 2-celled ascospores. Müller and von Arx (1962) transferred this species to Trichothyrium notatum in Trichothyriaceae. This and other genera in Trichothyriaceae (sensu Müller and von Arx 1962) do not appear to fit well in Microthyriaceae (see under Lichenopeltella) and fresh collections are needed for molecular analysis to confirm their taxonomic placement.

\section{Genus transferred to Venturiales incertae cedis}

Asteronia (Sacc.) Henn., Hedwigia 34: 104, 1895.

The generic type Asteronia sweetiae has globose, ostiolate ascomata that form on black mycelium, while asci form from the base of ascomata. These characters indicate that this genus is better placed in Asterinaceae or Meliolaceae (Wu et al. 2010), although a recent study by Zhang et al. (2011) might indicate a placement in Venturiales.

Dictyoasterina Hansf., Proc. Linn. Soc. London 159: 39 (1947)

The generic type Dictyoasterina conopharyngiae has superficial black mycelium with hyphopodia and clearly ostiolate, globose ascomata and Wu et al. (2010) suggest the genus should be transferred to a more suitable family, such as the Asterinaceae, although the presence of pseudoparaphyses should be considered. A more suitable family may be Venturiaceae (Zhang et al. 2011), however the presence of hyphopodia would be unusual.

Tothia Bat., in Toth, Annls hist.-nat. Mus. natn. hung. 52: 105 (1960).

Tothia fuscella (Sacc.) Bat., in Toth, Annls hist.-nat. Mus. natn. hung. 52: 106 (1960) 三 Microthyrium fuscellum Sacc., Michelia 2(no. 6): 57 (1880)

Wu et al. (2011b) epitypified the generic type T. fuscella and found it to be more closely related to Venturiales based on analysis of LSU and ITS rDNA genes.

\section{Genus transferred to Dothideomycetes genera incertae cedis}

Muyocopron Speg., Anal. Soc. cient. argent. 12(3): 113 (1881)

Ellisiodothis Theiss., Annls mycol. 12(1): 73 (1914)

Haplopeltis Theiss., Brotéria, sér. bot. 12: 88 (1914)

Peltella Syd. \& P. Syd., Annls mycol. 15(3/4): 237 (1917)

Peltopsis Bat., Publções Inst. Micol. Recife 260: 98 (1960) 
Saprobic on the surface of leaves or stems, as small black spots, superficial mycelium absent. Thyriothecia circular, scattered rarely coalescing, superficial, subcarbonaceous and brittle, black, flattened, basal layer slightly developed, with a central irregular ostiole; in section lenticular. Upper wall comprising radiating parallel cells, cells at margin branching. Peridium comprising two-strata, an outer layer composed of black-brown pseudoparenchymatous cells of compact thick-walled textura epidermoidea, an inner layer comprised of light brown cells of textura angularis. Hamathecium of dense pseudoparaphyses which are longer than asci and immersed in mucilage and inclined towards the center. Asci 8-spored, bitunicate, fissitunicate, pedicellate. Ascospores ellipsoidal to ovate with obtuse ends, hyaline, one-celled, with granular appearance.

Anamorphs reported for the genus: None.

\section{Type species}

Muyocopron corrientinum Speg., Anal. Soc. cient. argent. 12(3): 113 (1881) Fig. 29a-1

Saprobic on the surface of leaves or stems, as small black spots, superficial mycelium absent. Thyriothecia 77-108 $\mu \mathrm{m}$ high $\times 270-370 \mu \mathrm{m}$ diam, circular, scattered rarely coalescing, superficial, subcarbonaceous and brittle, black, flattened, basal layer slightly developed, with a central irregular ostiole; in section lenticular (Fig. 29a-c, e, g). Upper wall comprising radiating parallel cells, cells at margin branching (Fig. 29c, d). Peridium 19-30 $\mu \mathrm{m}$ wide, comprising two-strata, an outer layer composed of black-brown pseudoparenchymatous cells of compact thick-walled textura epidermoidea, an inner layer comprised of light brown cells of textura angularis (Fig. 29f, g). Hamathecium of dense pseudoparaphyses which are longer than asci and immersed in mucilage and inclined towards the center (Fig. 29i, 1). Asci 55-60×18-26 $\mu \mathrm{m}(\bar{x}=56.6 \times 21.3 \mu \mathrm{m}, n=15), 8$-spored, bitunicate, fissitunicate, ellipsoidal to wide fusiform, with a short 6-4×4-3 $\mu \mathrm{m}$ pedicel and lacking an ocular chamber, not bluing in IKI (Fig. 29h, i). Ascospores $18-15.5 \times 8.5-6 \mu \mathrm{m}$ $(\bar{x}=16.8 \times 7.5 \mu \mathrm{m}, n=20)$, irregularly arranged in asci, ellipsoidal to ovate with obtuse ends, hyaline, one celled, with granular appearance (Fig. 29j, k).

Anamorph: None reported.

Material examined: ARGENTINA, Corrientes, on leaves of Oncidium sp. (Orchidaceae), May 1881, C. Spegazzini (LPS 1538, holotype).

Muyocopron (as Myiocopron) was formally established by Spegazzini (1881) with Muyocopron corrientinum (as Myiocopron corrientinum) as the type species. This has resulted in confusion about the spelling of the name but Muyocopron is correct (Hawksworth et al. 1995). Saccardo (1883) re-described Muyocopron which was placed in Microthyriaceae when he introduced the family. Luttrell (1951) introduced Myiocopronaceae to "include all Hemisphaeriales with the Pleospora Type centrum". This name was invalidly published and Microthyriaceae is an earlier name (Eriksson 1981). Von Arx and Müller (1975), considered Muyocopron to belong in Botryosphaeriaceae, but this was rarely followed and Hawksworth et al. (1995), Kirk et al. (2008) and Lumbsch and Huhndorf (2010) refer Muyocopron to Microthyriaceae. Fresh collections of Muyocopron have been made by KoKo et al., (personal communication) and sequence data did not place the genus close to any currently defined order but did show some unanticipated relationship with Saccardoella rhizophila. This will require further confirmation.

Seynesiopeltis F. Stevens \& R.W. Ryan, in Stevens, Bulletin of the Bernice P. Bishop Museum, Honolulu, Hawaii 19: 69 (1925). 
Foliar epiphytes on the upper surface of leaves, causing black spots, usually confluent, forming black colonies. Mycelium superficial, sparse, septate, olive-green. Thyriothecia circular, solitary or gregarious, superficial, carbonaceous, unilocular, brown to black, basal layer poorly developed, lacking a distinct central ostiole. Upper wall comprising radiating parallel cells, cells at margin branching; in section shallow conical and dome-like. Peridium comprising two strata, inner rows of textura angularis. Pseudoparaphyses not observed. Asci 8-spored, bitunicate, fissitunicate, saccate, with a knob-like pedicel, and conspicuous ocular chamber (in Congo red). Ascospores irregularly 3-seriate, dark brown when mature, 1septate, strongly constricted at septum, asymmetrical, with a thick structured hyaline cell wall.

Anamorphs reported for the genus: None.

\section{Type species}

Seynesiopeltis tetraplasandrae F. Stevens \& R.W. Ryan, Bulletin of the Bernice P. Bishop Museum, Honolulu, Hawaii 19: 69-70 (1925). Fig. 30a-j

Foliar epiphytes on the upper surface of leaves, causing black spots, usually confluent, forming black colonies. Mycelium superficial, sparse, septate, olive-green. Thyriothecia 900-950 $\mu \mathrm{m}$ diam, 30-80 $\mu \mathrm{m}$ high, circular, solitary or gregarious, superficial, carbonaceous, unilocular, brown to black, basal layer poorly developed, lacking a distinct central ostiole (Fig. 30a-c). Upper wall comprising radiating parallel cells, cells at margin branching; in section lenticular (Fig. 30c, d). Peridium 30-44 $\mu \mathrm{m}$ wide, comprising two strata, with hyaline amorphous material at the outside, and 4-5 inner rows of black thickwalled cells of textura angularis (Fig. 30f). Hamathecium comprising asci, pseudoparaphyses not observed or lacking. Asci $88-123 \times 40-52 \mu \mathrm{m}, 8$-spored, bitunicate, fissitunicate, saccate, with a knob-like, 10-11×9-12 $\mu \mathrm{m}$ pedicel, and conspicuous ocular chamber (in Congo red) (Fig. 30e, g, i). Ascospores 37-57×18-30 $\mu \mathrm{m}$, irregularly 3-seriate, ellipsoidal to ovoid, light brown becoming dark brown when mature, 1-septate, strongly constricted at septum, and upper cell larger than the lower cell, with a thick structured hyaline cell wall (Fig. 30h, j).

Anamorph: None reported.

Material examined: HAWAII, Oahu, Hamakua, upper ditch trail, on leaves of Tetraplasandra (Araliaceae), 31 May 1921. F.L. Stevens (BISH 1089, holotype).

Seynesiopeltis was established by Stevens (1925) as a monotypic genus with $S$. tetraplasandrae. Stevens (1925) assigned this genus to Microthyriaceae and this is followed by Müller and von Arx (1962) and Lumbsch and Huhndorf (2010). This fungus resembles Seynesia but differs according to Stevens (1925) in its immersed, ostiolate, multilocular ascomata bearing setae. Stevens (1925) mentioned in the notes on this taxon that perithecia have one to several perithecia in one fungus body and that this bears setae, but this was not observed in the type specimen. This genus is atypical of Microthyriaceae, however a suitable family is hard to find and so the genus should be included in Dothideomycetes incertae cedis until it can be recollected.

Hypocreales incertae cedis-Hidakaea I. Hino \& Katum., Bulletin of the Faculty of Agriculture, Yamaguchi University 6: 38, 1955.

Wu et al. (2010) suggest that Hidakaea belongs in Hypocreales incertae cedis.

Rhytismataceae—Helminthopeltis Sousa da Câmara, Agronomia Lusitana 12: 102, 1950. 
Wu et al. (2010) concluded this genus belongs to Rhytismataceae.

Stictidaceae—Actinomyxa Syd. \& P. Syd., Annls mycol. 15(1/2): 146 (1917)

Morphological characters of Actinomyxa australiensis are typical of genera in Stictidaceae (Wu et al. 2011a).

Ascomycota genera incertae cedis-Stegothyrium denudans (Rehm) Höhn. Sitzber. K. Akad. Wiss. Wien, Math.-naturw. Kl., Abt. I 127: 382 (1918)

This unusual genus has thick-walled asci that appear to be bitunicate, but there is a J-apical ring, which is indicative of unitunicate asci. Stegothyrium is placed in Ascomycota genera incertae cedis by Wu et al. (2011a).

\section{Doubtful, uncertain, poorly known and unexamined genera}

Asterinella Theiss., Annls mycol. 10(2): 160 (1912)

Asterinella puiggarii (Speg.) Theiss., Brotéria, sér. bot. 10 (2): 116 (1912)

三 Asterina puiggarii Speg., Anal. Soc. cient. argent. 12 (3): 99 [no. 114] (1881)

Müller and von Arx (1962) included Asterinella in Microthyriaceae and based on their drawing and on the drawing on the herbarium packet (http://www.cybertruffle.org.uk/spegazzini/eng/001377a_.htm) this classification seems correct. The central ostiole however, is not distinct in either drawing and the cells of the peridium are not neatly arranged in parallel rows as in Microthyrium. Furthermore, the clavate asci and light brown ascospores differ. Since Tothia does not cluster in Microthyriaceae and is somewhat similar to Asterinella the genus should be questionably retained in the family until molecular sequence data shows otherwise.

There are 101 records Asterinella in Index Fungorum (http://www.indexfungorum.org/names/Names.asp) and about six widespread species estimated in Kirk et al. (2008). In some species however, thyriothecia open by stellate dehiscence (e.g. A. argyreicae Hosag., M.P. Balakr. \& Goos, A. pterigotae Hosag. \& T.K. Abraham (Hosagoudar et al. 1996; Hosagoudar and Abraham 1998), and therefore the concepts of the genus need to be established and then monographed. This may be an earlier genus for Maublancia (see under that entry).

Cirsosiopsis Butin \& Speer, Sydowia 31(1-6): 10 (1979) [1978]

Cirsosiopsis violacescens Butin \& Speer, Sydowia 31(1-6): 10 (1979) [1978]

This monotypic genus was introduced from living leaves of Araucaria augustifolia from Brazil. Based on the drawing provided by Butin and Speer (1978), C. violacescens is not typical of Microthyriaceae. It is typical of the "erect ascomata group of Asterinaceae" which may be Venturiaceae and needs recollecting and sequencing. However it should be excluded from Microthyriaceae and questionably placed Asterinaceae.

Cyclotheca Theiss., Annls mycol. 12(1): 70 (1914)

Calopeltis Syd., Annls mycol. 23(3/6): 392 (1925)

Hariotula G. Arnaud, C. r. hebd. Séanc. Acad. Sci., Paris 164: 890 (1917)

Seynesiospora Bat., Publções Inst. Micol. Recife 260: 118 (1960) 
Synostomella Syd., Annls mycol. 25(1/2): 43 (1927)

Synpeltis Syd. \& P. Syd., Annls mycol. 15(3/4): 221 (1917)

Thyrosoma Syd., Annls mycol. 19(5/6): 307 (1921)

Cyclotheca miconiae (P. Syd.) Theiss., Annls mycol. 12(1): 70 (1914)

$\equiv$ Polystomella miconiae P. Syd., Bull. Herb. Boissier, 2 sér. 1: 87 (1901)

This genus name is illegitimate (Art. 53.1) as it is a homonym of Cyclotheca Moq. 1849 (Gyrostemonaceae).

Müller and von Arx (1962) described the taxon as C. melastomatis (Pat.) Arx which is an earlier name for $C$. miconiae and appears to have a distinct central ostiole typical of Microthyriaceae. Inconspicuous hyphae penetrate the leaf cells and ascospores are apiosporous. Thus the genus appears to be typical of Microthyriaceae, being distinct in having apiospores lacking appendages. There are 17 records of Cyclotheca in Index Fungorum (http://www.indexfungorum.org/Names/Names.asp) and Kirk et al. (2008) estimates the genus comprises nine species. The genus name however, is invalid, thus one of the synonyms (e.g. Synpeltis Syd. \& P. Syd., Synostomella Syd.) may be a suitable alternative - a problem requiring further study.

Hugueninia J.L. Bezerra \& T.T. Barros, Publções Inst. Micol. Recife 643: 5 (1970)

Hugueninia freycinetiae J.L. Bezerra \& T.T. Barros, Publções Inst. Micol. Recife 643: 6 (1970)

This genus name is illegitimate (Art. 53.1) as it is a homonym of non Hugueninia Rchb. 1832 (Cruciferae).

This species was studied by Hyde (1997) who transferred it to Stomiopeltis (Micropeltidaceae) and is also typical of Cyclotheca, except that ascospores are not reported to become olivaceous-brown at maturity (Bezerra et al. 1970). Hyde (1997) state that thyriothecia have a central rounded ostiole but do not illustrate this (page 17, Fig 76) while the upper wall is composed of irregular radiating cells. Bezerra et al. (1970) illustrate a distinct ostiolar pore and irregularly radiating cells at the periphery of the thyriothecia.

Because the genus name is illegitimate and appears to have few differences from Cyclotheca we suggest that the genus is considered a synonym of Cyclotheca until it can be recollected and sequenced.

Cyclotheca freycinetiae (J.L. Bezerra \& T.T. Barros) H.X. Wu \& K.D. Hyde comb. nov. 三 Hugueninia freycinetiae J.L. Bezerra \& T.T. Barros, Publções Inst. Micol. Recife 643: 6 (1970)

MycoBank 563441

Petrakiopeltis Bat., A.F. Vital \& Cif., in Batista, Costa \& Ciferri, Publções Inst. Micol. Recife 90: 10 (1957)

Petrakiopeltis byrsonimae Bat., A.F. Vital \& Cif., in Batista, Costa \& Ciferri, Publções Inst. Micol. Recife 90: 10 (1957)

This is a poorly known genus and we have been unable to locate the type material or original publication. 
Phaeothyriolum Syd., Annls mycol. 36(4): 305 (1938)

Phaeothyriolum eucalyptinum Syd., Annls mycol. 36 (4): 305 (1938)

三 Mycomicrothelia eucalyptina (Syd.) E. Müll., in Müller \& von Arx, Beitr. Kryptfl. Schweiz 11(no. 2): 327 (1962)

We have not been able to examine the generic type which was considered a synonym of Mycomicrothelia eucalyptina by Müller and von Arx (1962). The species has been wellstudied by Swart (1986) and occurs on Eucalyptus leaves in Australia and New Zealand. Swart (1986) found an earlier name in Phaeothyriolum microthyrioides (G. Winter) H.J. Swart and P. eucalyptinum is synonymised. Extensive drawings are provided by Swart (1986) and the fungus lacks a distinct ostiole as in Microthyrium and may be typical of Asterinaceae.

Phragmaspidium Bat., Publções Inst. Micol. Recife 260: 109 (1960)

Phragmaspidium corruscans (Rehm) Bat., Publções Inst. Micol. Recife 260: 110 (1960)

三 Micropeltis corruscans Rehm, Philipp. J. Sci., C, Bot. 8: 254 (1913)

The generic type could not be located. In the description of Rehm (1913) the ascomata are reported from living leaves and ascospores are small and 4-celled suggesting this belongs to Micropeltidaceae.

Platypeltella Petr., in Sydow \& Petrak, Annls mycol. 27(1/2): 62 (1929)

Asterinopeltis Bat. \& H. Maia, in Batista, Maia \& Farr, Revta Biol., Lisb. 1(3-4): 293 (1958)

Platypeltella smilacis Petr., Annls mycol. 27(1/2): 62 (1929)

This genus comprises three species occurring on monocotyledons in the neotropics (Farr 1982). The type is illustrated by Farr (1982) and although the arrangement of the cells of the peridium are microthyriaceous, the pore may be typical of Asterinaceae. We have not been able to loan the type material of this genus and thus consider the familial placement as uncertain.

Sapucchaka K. Ramakr., J. Indian bot. Soc. 35: 115 (1956)

Sapucchaka madreeya K. Ramakr., J. Indian bot. Soc. 35: 115 (1956)

This is a poorly known genus and we have been unable to locate the type material or original publication. Von Arx and Müller (1975) mention this species is similar to Muyocopron but has basally appendages ascospores. This might be better accommodating in Botryosphaeriales but must be considered doubtful until it is recollected.

Trichopeltella Höhn., Sber. Akad. Wiss. Wien, Math.-naturw. Kl., Abt. 1 119: 458 [66 repr.] (1910)

Raciborskiella Speg., Boln Acad. nac. Cienc. Córdoba 23: 509 (1919)

Trichopeltella montana (Racib.) Höhn., Sber. Akad. Wiss. Wien, Math.-naturw. Kl., Abt. 1 119: 458 [66 repr.] (1910)

$\equiv$ Trichopeltis montana Racib., Bull. int. Acad. Sci. Lett. Cracovie, Cl. sci. math. nat. Sér. B, sci. nat. 3: 378 (1909) 
三 Seynesia montana (Racib.) Sacc. \& Trotter, Syll. fung. (Abellini) 22: 524 (1913)

We could not locate the type material. Raciborski (1909) described a Microthyriaceae-like fungus with a minute central ostiole and light brown bicelled ascospores.

Trichopeltina Theiss., Zentbl. Bakt. ParasitKde, Abt. II 39: 630 (1914)

Trichopeltina labecula (Mont.) Theiss., Zentbl. Bakt. ParasitKde, Abt. II 39: 630 (1914)

三 Asteroma labecula Mont., Annls Sci. Nat., Bot., sér. 2 14: 328 (1840)

The is the generic type of Trichopeltinaceae and was studied by Eriksson (1981) who concluded that as the original material has not been re found the genus and "the whole family is doubtful".

Trichopeltum Bat., Cif. \& C.A.A. Costa, in Batista, Costa \& Ciferri, Publções Inst. Micol. Recife 90: 20 (1957)

Trichopeltum hawaiiense Bat. \& C.A.A. Costa [as 'hawaiiensis'], in Batista, Costa \& Ciferri, Publções Inst. Micol. Recife 90: 21 (1957)

This is a poorly known genus and we have been unable to locate the type material or original publication.

Trichothyriella Theiss., Beih. bot. Cbl. 32(2): 4 (1914)

Trichothyriella quercigena (Berk. ex Cooke) Theiss., Beih. bot. Cbl. 32(2): 4 (1914)

$\equiv$ Asterina quercigena Berk. ex Cooke, Grevillea 13 (no. 67): 67 (1885)

$\equiv$ Asterula quercigena (Berk. ex Cooke) Sacc., Syll. fung. (Abellini) 9: 376 (1891)

We have not seen this specimen which was treated as a synonym of Trichothyrium by Müller and von Arx (1962). The brief description provided by Cooke (1885) indicates that this may be microthyriaceous.

Trichothyrinula Petr., Sydowia 4(1-6): 171 (1950)

Trichothyrinula sydowii Petr., Sydowia 4(1-6): 171 (1950)

We have been unable to locate this specimen. The genus has been treated in Trichothyriaceae by Müller and von Arx (1962) and von Arx and Müller (1975). It is a leaf parasite so until the specimen can be found we prefer to questionably leave this in Microthyriaceae.

\section{Discussion}

In this paper we re-examine family and generic types with thyriothecia previously associated with Microthyriaceae. We illustrate the Microthyriaceae and generic types of Micropeltidaceae and provide new sequence data for a number of species and genera. Our phylogenetic analysis underscores the high genetic diversity for thyriotheciate species and illustrate that no clade that can be clearly defined as Microthyriales. Nuclear ribosomal data indicate multiple polyphyletic lineages for species now placed in Microthyriaceae and Micropeltidaceae and it is likely that these familial concepts will have be defined more narrowly in the future. Some unexpected DNA based phylogenetic relationships were found, such as those between Muyocopron and Saccardoella. This requires corroboration with more complete taxon sampling as well as additional non ribosomal markers. There are few 
morphological differences between Aulographaceae, Asterinaceae and Palmulariaceae and these families may need recircumscription. Nine genera are transferred from Microthyriaceae to Asterinaceae, and two to Aulographaceae based on the splitting or dissolving nature of the thyriothecia to release ascospores. Although Asterinales have been used for this family, the order was considered synonymous with Capnodiales (Kirk et al. 2008), although Hofmann et al. (2010) indicate otherwise and further sequence data is urgently needed. Three genera are transferred to Micropeltidaceae Three genera are transferred to Trichothyriaceae and an argument is made for retention of this family. Brefeldiella in Brefeldiellaceae also form extensively developed lobed thalli made up of radially arranged cells and needs to be characterised with sequence data.

Asterinaceae and Microthyriaceae are thought to obtain nutrients by penetrating the plant with hyphopodia forming haustoria, innate nutrient mycelium, or leaf permeating hypostroma or pseudostroma, however further work is needed to establish whether this biological character is taxonomically informative. Nevertheless, based on the preliminary findings of this study a high level of genetic diversity is to be expected.

\section{Supplementary Material}

Refer to Web version on PubMed Central for supplementary material.

\section{Acknowledgments}

The Research Institute of Resource Insects, Chinese Academy of Forestry provided financial support for the PhD study of Haixia Wu. Funds for research were provided by the Grant for Essential Scientific Research of National Non-profit Institute (no. CAFYBB2007002). The second author acknowledges support by the Intramural Research Program of the NIH, National Library of Medicine. The authors also thank Xiaoming Chen, Chen Hang and Mao Tao (The Research Institute of Resource Insects, Chinese Academy of Forestry, China), Jiankui Liu (Mae Fah Luang University, Thailand, MFU) and Cai Lei (Institute of Microbiology, Chinese Academy of Sciences, Beijing, China) for their valuable help. The Thai work was supported by Thailand Research Fund BRG528002 and the Global Research Network for Fungal Biology and King Saud University are also thanked for support.

\section{References}

Arnaud G. Lés Asterinées. Annals d'École National d'Agriculture de Montpellier, série 2. 1918; 16:1288.

von Arx JA, Müller E. A re-evaluation of the bitunicate ascomycetes with key to families and genera. Stud Mycol. 1975; 9:1-159.

Barr ME. Buergenerula and the Physosporellaceae. Mycologia. 1976; 68(3):611-621.

Barr, ME. Publ by the author. Amherst, Massachusetts: 1987. Prodomus to class Loculoascomycetes.

Batista AC. Monografia dos fungos Micropeltaceae. Publicações Instituto de Micologia da Universidade do Recife. 1959; 56:1-519.

Batista AC. Resendea, um novo gênero de Polystomellaceae, Brotéria, Série Trimestral: Ciencias Naturais. 1961; 30:87-91.

Batista AC, Gayão TJ. Vas e curiosas especies de Asterinaceae. An IV Congr Nac Soc Bot Brasil. 1953:160-176.

Batista AC, Vital AF. Dois novos gêneros de fungos Polystomellaceae. Revista de Biologia Lisbõa. 1958; 1(3-4):280-286.

Batista AC, Maia HS. Govindua, N. gen. e outros. Asterinaceae. Revista de Biologia Lisbõa. 1960; 2:95-102.

Batista AC, Maia HS, Vital AF. Alguns fungos hiperparasitas. Anais da Sociedade de Biologia de Pernambuco. 1955; 13(2):94-107.

Batista AC, Costa AA, Ciferri R. Orgânogênese e sistemática dos fungos Trichopeltinaceae (Theiss.) emend. Nobis. Atti dell'Istituto Botanico della Università e Laboratorio Crittogamico di Pavia. 1957; 15:35-56. (Ser. 5). 
Batista AC, Maia HS, Farr ML. Novos generos e novas especies de fungos Asterinaceae. Revista de Biologia Lisbõa. 1958; 1 (3-4):287-298.

Batista AC, Cavalcante WA, Peres GP. Novas espécies de Microthyriaceae. Atas Instituto de Micologia, Universidade do Recife. 1967; 5:213-224.

Batista AC, Bezerra JL, Barros TT, Leal FB. Byssopeltis-um novo representante da micoflora do Maranhão. Publicações. Instituto de Micologia da Universidade Federal de Pernambuco. 1970; 636:1-10.

Bezerra, JL.; Cavalcante, WA. Batistamnus Bezerra \& Cavalcanti n.gen. e outros Trichopeltinaceae. Vol. 5. Atas Instituto de Micologia, Universidade do Recife; 1967. p. 253-270.

Bezerra JL, Barros TT, Leal FB. Hugueninia, um novo genero da familia Microthyriaceae. Publ Inst Micol Recife. 1970; 643:1-11.

Bigelow HE, Barr ME. Contribution to the fungus flora of northeastern North America. Rhodora. 1969; 71:178-203.

Butin H, Speer EO. Über einige parasitische Ascomyceten auf Nadeln der Brasilianischen Araukarie. Sydowia. 1978; 31(1-6):9-26.

Castersana J. Selection of conserved blocks from multiple alignments for their use in phylogenetic analysis. Mol Biol Evol. 2000; 17:540-552. [PubMed: 10742046]

Chardón CE, Toro RA. Mycological explorations of Venezuela. Monographs of the University of Puerto Rico Series B. 1934; 2:1-351. 34 plates.

Chevenet F, Brun C, Banuls AL, Jacq B, Christen R. TreeDyn: towards dynamic graphics and annotations for analyses of trees. BMC Bioinformatics. 2006; 7:439. [PubMed: 17032440]

Chomnunti, et al. 2011 in press in this issue of FD.

Ciferri R. Schedae mycologicae. XXXV-XCVIII. Atti dell' Istituto Botanico della Università e Laboratorio Crittogamico di Pavia Ser. 5. 1962; 19(5):85-139. 8 pls, 55 figs.

Clements, FE.; Shear, CL. Genera of Fungi. 2. Vol. i-vii. USA, New York: H.W. Wilson Company; 1931. p. 49658 plates

Cooke MC. Synopsis pyrenomycetum. Grevillea. 1885; 13(67):61-72.

Crous PW, Kendrick WB. Arnaudiella eucalyptorum sp. nov. (Dothideales, Ascomycetes) and its hyphomycetous anamorph. Can J Bot. 1994; 72(1):59-64.

Desmazières JBHJ. Huitième notice sur quelques plantes cryptogames, la plupart inédites, récemment découvertes en France. Annales des Sciences Naturelles, Botanique: 15 Série. 1841; 2:129-146.

Díaz Arias MM, Batzer JC, Harrington TC, Wong AW, Bost SC, Cooley DR, Ellis MA, Hartman JR, Rosenberger DA, Sundin GW, Sutton TB, Travis JW, Wheeler MJ, Yoder KS, Gleason ML. Diversity and biogeography of sooty blotch and flyspeck fungi on apple in the eastern and midwestern United States. Phytopathology. 2010; 100:345-355. [PubMed: 20205538]

Doidge EM. South African Microthyriaceae. Bothalia. 1942; 4:273-344.

Ellis JP. British Microthyrium species and similar fungi. Trans Br Mycol Soc. 1976; 67(3):381-194.

Ellis JP. The genera Trichothyrina and Actinopeltis in Britain. Trans Br Mycol Soc. 1977; 68(3):145155.

Eriksson OE. The families of the bitunicate ascomycetes. Opera Botanica. 1981; 60:1-220.

Etayo J, Sancho LG. Hongos liquenícolas del sur de Sudamérica, especialmente de Isla Navarino (Chile). Bibliotheca Lichenologica. 2008; 98:1-302.

Farr ML. A third species of Platypeltella (Microthyriaceae). Mycotaxon. 1982; 15:448-452.

Farr ML. The genus Asterinema (Ascomycetes, Microthyriaceae). Mycologia. 1983; 75:1036, 10361043.

Farr ML. Amazonian foliicolous fungi. IV. Some new and critical taxa in Ascomycotina and associated anamorphs. Mycologia. 1987; 79(1):97-116.

Ferrer A, Miller AN, Shearer CA. Minutisphaera and Natipusilla: two new genera of freshwater Dothideomycetes. Mycologia. 2011; 103:411-423. [PubMed: 21415293]

Hall TA. BioEdit: a user-friendly biological sequence alignment editor and analysis program for Windows 95/98/NT. Nucleic Acids Symp Series. 1999; 41:95-98. 
Hansford CG. The foliicolous Ascomycetes, their parasites and associated fungi. Mycological Papers. 1946; 15:1-240.

Hansford CG. Australian fungi. III. New species and revisions. Proc Linn Soc New S Wales. 1956; 81(1):23-51.

Hawksworth DL, Eriksson OE. The names of accepted orders of ascomycetes. Systema Ascomycetum. 1986; 5(1):175-184.

Hawksworth DL, Santesson R. A revision of the lichenicolous fungi previously referred to Phragmonaevia. Bibliotheca Lichenologica. 1990; 38:121-143.

Hawksworth, DL.; Kirk, PM.; Sutton, BC.; Pegler, DN. Ainsworth \& Bisby's dictionary of the fungi. 7. CAB International; Wallingford: 1983.

Hawksworth, DL.; Kirk, PM.; Sutton, BC.; Pegler, DN. Ainsworth \& Bisby’s dictionary of the fungi. 8. CABI; Wallingford: 1995.

Hofmann, TA. PhD thesis. 2010. Plant parasitic Asterinaceae and Microthyriaceae from the Neotropics (Panama); p. 408The faculty of biological sciences at the J.W. Goethe-University Frankfurt am Main, Germany

Hofmann TA, Piepenbring M. New records and host plants of fly-speck fungi from Panama. Fungal Diversity. 2006; 22:55-70.

Hofmann TA, Kirschner R, Piepenbring M. Phylogenetic relationships and new records of Asterinaceae (Dothideomycetes) from Panama. Fungal Diversity. 2010; 43:39-53.

Höhnel F. Ergebnisse der Botanischen Expedition der Kaiserlichen Akademie der Wissenschaften nach Süd-Brasilien 1901. Eumycetes et Myxomycetes. Denkschriften der Akademie der Wissenschaften (Wien), Mathnat Kl. 1907; 83:1-45.

Höhnel FXR. Fragmente zur Mykologie. XXII Mitteilungen, nr. 1092 bis 1153. Sber Akad Wiss Wien Mathematische-Naturwissenschaftliche Klasse, Abt 1. 1919; 128:549-634.

Hosagoudar VB, Abraham TK. Four new foliicolous ascomycetes from Kerala. India Mycol Res. 1998; 102(2):184-186.

Hosagoudar VB, Balakrishnan MP, Goos RD. Some Asterinella, Asterostomella and Echidnodella species from southern India. Mycotaxon. 1996; 59:489-498.

Huelsenbeck JP, Ronquist F. MRBAYES: Bayesian inference of phylogenetic trees. Bioinformatics. 2001; 17:754-755. [PubMed: 11524383]

Huelsenbeck JP, Ronquist F, Nielsen R, Bollback JP. Bayesian inference of phylogeny and its impact on evolutionary biology. Science. 2001; 294:2310-2314. [PubMed: 11743192]

Hughes SJ. Fungi from the Gold Coast. II. Mycological Papers. 1953; 50:1-104.

Hyde KD. The genus Saccardoella from intertidal mangrove wood. Mycologia. 1992; 84:803-810.

Hyde KD. Ascomycetes described on Freycinetia. Sydowia. 1997; 49 (1):1-20.

Hyde KD, McKenzie EHC, KoKo TW. Towards incorporating anamorphic fungi in a natural classification-checklist and notes for 2010. Mycosphere. 2011; 2:1-88.

Ignácio, CA.; Cannon, PF. CBS Biodiversity Series 8. CBS Fungal Biodiversity Centre; 2008. The genera of Parmulariaceae.

Katoh K, Asimenos G, Toh H. Multiple alignment of DNA sequences with MAFFT. Meth Mol Biol. 2009; 537:39-64.

Kirk, PM.; Cannon, PF.; David, JC.; Stalpers, JA. Ainsworth \& Bisby's dictionary of the fungi. 9. CABI; Wallingford: 2001.

Kirk, PM.; Cannon, PF.; Minter, DW.; Stalpers, JA. Ainsworth \& Bisby's dictionary of the fungi. 10. CABI; Wallingford: 2008.

Krishnamurthy, KV.; Hariharan, GN. Lichens. In: Johri, BM., editor. Botany in India. History and progress. Science Publishers; Lebanon: 1996. p. 375-385.

Liu K, Raghavan S, Nelesen S, Linder CR, Warnow T. rapid and accurate large-scale coestimation of sequence alignments and phylogenetic trees. Science. 2009; 324:1561-1564. [PubMed: 19541996]

Lumbsch HT, Huhndorf SM. Myconet volume 14, part one. Outline of ascomycota-2009, part two. Notes on ascomycete systematics. Nos. 4751-5113. Fieldiana, Life and Earth Sciences. 2010; 1:164.

Luttrell ES. Taxonomy of the Pyrenomycetes. University of Missouri Studies. 1951; 24(3):1-120. 
Luttrell, ES. Loculoascomycetes. In: Ainsworth, GC.; Sparrow, FK.; Sussman, AS., editors. The fungi. An advanced treatise. Academic Press; 1973. p. 135-219.

Miller, MA.; Pfeiffer, W.; Schwartz, T. Creating the CIPRES Science Gateway for inference of large phylogenetic trees. Proceedings of the Gateway Computing Environments Workshop (GCE); 14 Nov. 2010; New Orleans, LA. 2010. p. 1-8.

Montagne, JPFC. Botanique. Plantes cellulaires. In: de la Sagra, R., editor. Histoire Physique Politique et Naturelle de l'Ile de Cuba. Vol. 2. France: 1842. p. 1-549.

Müller E, von Arx JA. Die Gattungen der didymosporen Pyrenomyceten. Beiträge zur Kryptogamenflora der Schweiz. 1962; 11 (2):1-922.

Petrak F. Mykologische Notizen. IX. Annales Mycologici. 1927; 25:193-343.

Petrak F, Ciferri R. Fungi Dominicani. II. Annales Mycologici. 1932; 30(3-4):149-353.

Raciborski M. Parasitische und epiphytische Pilze Javas. Bulletin International de l'Academie des Sciences de Cracovie, Classe des Sciences Mathematiques et Naturelles. 1909; 3:346-394.

Ramaley AW. Three species of Microthyrium from Nolina. Mycotaxon. 1999; 70:7-16.

Rehm H. Ascomycetes philippinenses-II. Philippine Journal of Science, Section C, Botany. 1913; $8: 251-263$.

Reynolds DR, Gilbert GS. Epifoliar fungi from Queensland, Australia. Aust Syst Bot. 2005; 18:265289.

Reynolds DR, Gilbert GS. Epifoliar fungi from Panama. Cryptogamie, Mycologie. 2006; 27(3):249_ 270.

Ryan RW. The Microthyriaceae of Porto Rico. Mycologia. 1924; 16:177-196.

Ryan RW. The development of the perithecia in the Microthyriaceae and a comparison with Meliola. Mycologia. 1926; 18:100-110.

Saccardo, PA. Sylloge Fungorum (Abellini). Vol. 2. Italy, Pavia: P.A. Saccardo; 1883. p. 1-815.p. iilxix.

Saccardo, PA. Sylloge Fungorum. Vol. 9. Italy, Pavia: P.A. Saccardo; 1891. p. 1-1141.

Schoch CL, Crous PW, Groenewald JZ, Boehm EW, Burgess TI, de Gruyter J, de Hoog GS, Dixon LJ, Grube M, Gueidan C, Harada Y, Hatakeyama S, Hirayama K, Hosoya T, Huhndorf SM, Hyde KD, Jones EB, Kohlmeyer J, Kruys A, Li YM, Lucking R, Lumbsch HT, Marvanova L, Mbatchou JS, McVay AH, Miller AN, Mugambi GK, Muggia L, Nelsen MP, Nelson P, Owensby CA, Phillips AJ, Phongpaichit S, Pointing SB, Pujade-Renaud V, Raja HA, Plata ER, Robbertse B, Ruibal C, Sakayaroj J, Sano T, Selbmann L, Shearer CA, Shirouzu T, Slippers B, Suetrong S, Tanaka K, Volkmann-Kohlmeyer B, Wingfield MJ, Wood AR, Woudenberg JH, Yonezawa H, Zhang Y, Spatafora JW. A class-wide phylogenetic assessment of Dothideomycetes. Stud Mycol. 2009; 64:1-15. [PubMed: 20169021]

Schoch CL, Shoemaker RA, Seifert KA, Hambleton S, Spatafora JW, Crous PW. A multigene phylogeny of the Dothideomycetes using four nuclear loci. Mycologia. 2006; 98:1041-1052. [PubMed: 17486979]

Sivanesan A, Vánky K. New species of foliicolous Loculoascomycetes on Dysoxylum, Melaleuca and Syzygium from Queensland, Australia. Fungal Divers. 2002; 11:151-158.

Spegazzini C. Fungi argentini additis nonnullis brasiliensibus montevideensibusque. Pugillus quartus (Continuacion) Anales de la Sociedad científica argentina. 1881; 12(3):97-117.

Spooner BM, Kirk PM. Observations on some genera of Trichothyriaceae. Mycol Res. 1990; 94(2): 223-230.

Stamatakis A. RAxML-VI-HPC: maximum likelihood-based phylogenetic analyses with thousands of taxa and mixed models. Bioinformatics. 2006; 22:2688-2690. [PubMed: 16928733]

Stamatakis A, Hoover P, Rougemont J. A rapid bootstrap algorithm for the RAxML Web Servers. Syst Biol. 2008; 57:758-771. [PubMed: 18853362]

Stevens FL. Hawaiian fungi. Bulletin of the Bernice P Bishop Museum Honolulu. 1925; 19:1-189.

Stevens FL, Manter HW. The Hemisphaeriaceae of British Guiana and Trinidad. Botanical Gazette. 1925; 79(3):265-296.

Stevens FL, Ryan MH. The Microthyriaceae. Illinois Biology Monographs. 1939; 17(2):1-138.

Subhedar AW. An undescribed species of Calothyriopsis on apple. Reinwardtia. 1980; 9(4):421-424. 
Swart HJ. Australian leaf-inhabiting fungi XXII. Microthyrium-like fungi on Eucalyptus. Trans Br Mycol Soc. 1986; 87:81-91.

Sydow H. Fungi venezuelani. Annales Mycologici. 1930; 28(1-2):29-224.

Sydow H, Sydow P. Fungi from northern Palawan. Philippine Journal of Science Section C, Botany. 1914; 9(2):157-189.

Sydow H, Sydow P. Fungi amazonici a cl. E. Ule lecti. Annales Mycologici. 1916; 14(1-2):65-97.

Theissen F. Hemisphaeriales. Annales Mycologici. 1913; 11(5):425-467.

Theissen F. Die Trichothyriaceen. Beihefte zum Botanischen Zentralblatt. 1914; 32:1-16. (Abt. II).

Wu HX, Li YM, Chen H, Hyde KD. Studies on Microthyriaceae: some excluded genera. Mycotaxon. 2010; 113:147-156.

Wu HX, Hyde KD, Chen H. Studies on Microthyriaceae: placement of Actinomyxa, Asteritea, Cirsosina, Polystomellina and Stegothyrium. Cryptogamie Mycologie. 2011a; 32:3-12.

Wu HX, Jaklitsch WM, Voglmayr H, Hyde KD. Epitypification, morphology and phylogeny of Tothia fuscella. Mycotaxon. 2011b:118. in press.

Yang HL, Sun GY, Batzer JC, Crous PW, Groenewald JZ, Gleason ML. Novel fungal genera and species associated with the sooty blotch and flyspeck complex on apple in China and the USA. Persoonia. 2010; 24:29-37. [PubMed: 20664758]

Zhang Y, Wang HK, Fournier J, Crous PW, Jeewon R, Pointing SB, Hyde KD. Towards a phylogenetic clarification of Lophiostoma/Massarina and morphologically similar genera in the Pleosporales. Fungal Diversity. 2009; 38:225-251.

Zhang Y, Crous PW, Schoch CL, Bahkali AH, Guo LD, Hyde KD. A molecular, morphological and ecological re-appraisal of Venturiales - a new order of Dothideomycetes. Fungal Diversity. 2011; 5110.1007/s13225-011-0141-x

Zhang Y, Crous PW, Schoch CL, Hyde KD. Pleosporales. Fungal Diversity. 2012; 53:1-225. (in press). 10.1007/s13225-011-0117-x 


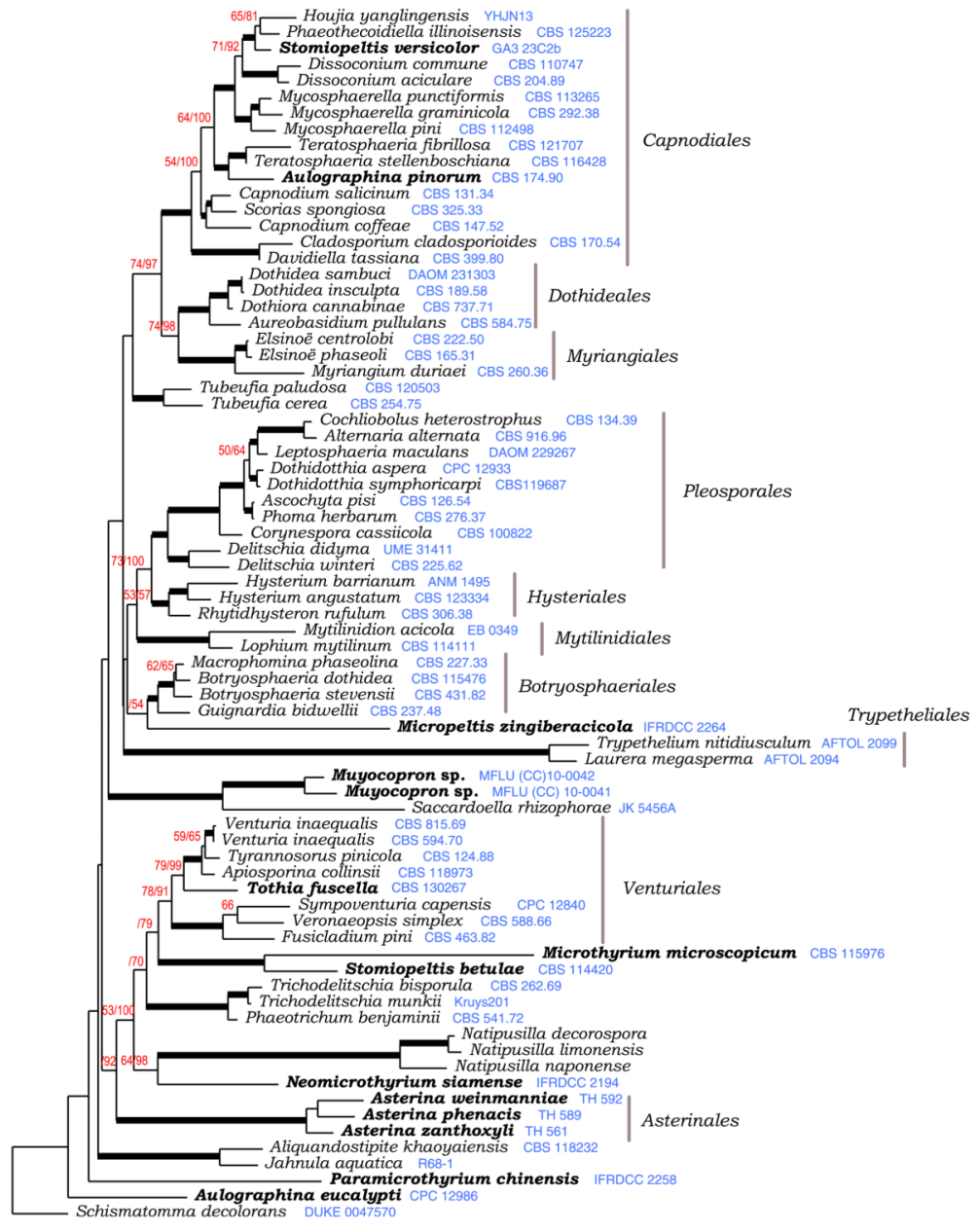

Fig. 1.

A RAxML maximum likelihood tree from obtained from a data set of 75 taxa including representatives of all known orders in Dothideomycetes and potential species included in Microthyriaceae, comparing two genes (SSU, LSU) with Schismatomma decolorans, a member of Arthoniomycetes as outgroup. The first set of numbers above the nodes are bootstraps from 1000 repetitions and the second represent Bayesian posterior probabilities expressed as percentages. Only values above $50 \%$ are shown and branches recovered in more than $80 \%$ of bootstrap trees as well as $95 \%$ of Bayesian tree are thickened. Culture and voucher numbers are indicated after species names and thyriotheciate taxa are bolded 

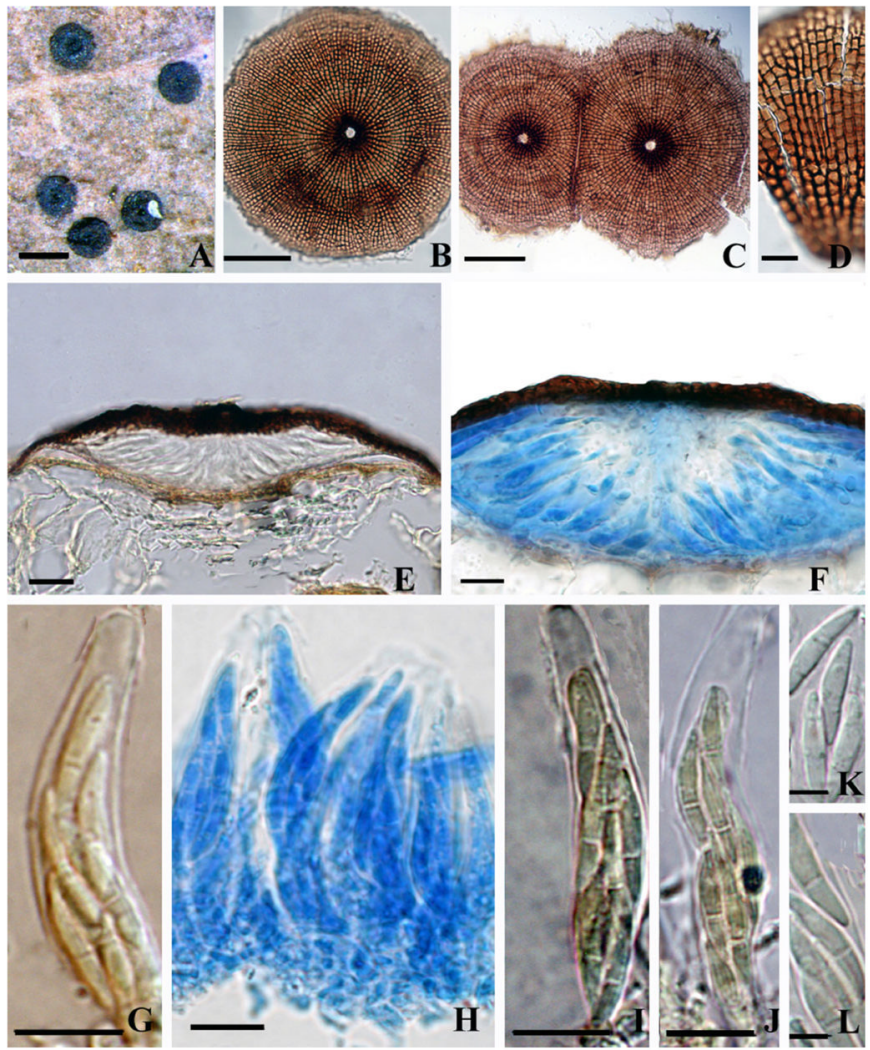

Fig. 2. Microthyrium microscopicum (isotype)

a Appearance of ascomata on the host surface. $\mathbf{b}, \mathbf{c}, \mathbf{d}$ Squash mount of ascomata. Note central ostiole and radiating cells of the thyriothecium. e, f Section of ascoma. Note the peridium ( $\mathrm{F}$ mounted in cotton blue reagent). $\mathbf{g}-\mathbf{j}$ Asci ( $\mathrm{H}$ mounted in cotton blue reagent). k, I Ascospores. Scale bars: A= $500 \mu \mathrm{m}, \mathrm{B}, \mathrm{C}=200 \mu \mathrm{m}, \mathrm{E}=20 \mu \mathrm{m}, \mathrm{D}, \mathrm{F}-\mathrm{J}=10 \mu \mathrm{m}, \mathrm{K}-\mathrm{L}=5$ $\mu \mathrm{m}$ 


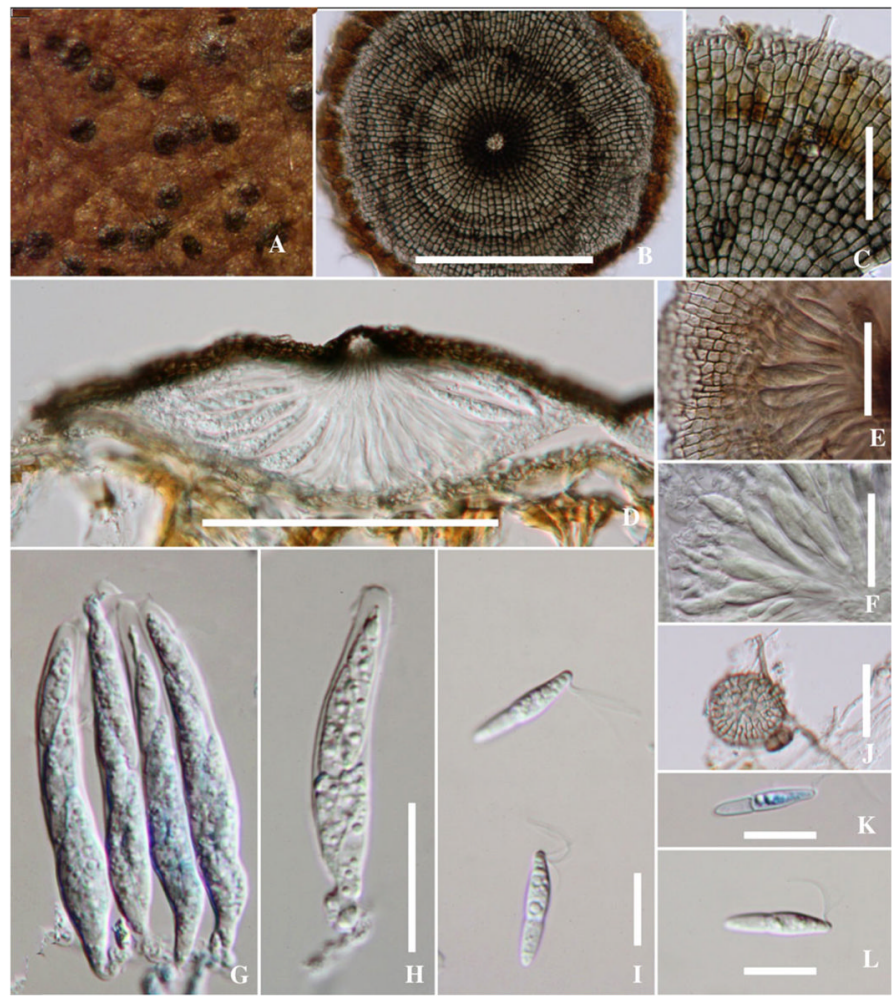

Fig. 3. Microthyrium microscopicum (MFLU09-0653) on leaf

a Thyriothecium superficial on host. b-c, e-f Thyriothecium with ostiole. $\mathbf{c}$ Arrangment of thyriothecium wall. $\mathbf{d}$ Section through the thyriothecium with thin peridium. $\mathbf{g}-\mathbf{h}$ Bitunicate asci. $\mathbf{j}$ Hyphae and young thyriothecium. i, k-l Ascospores with appendages. Scale bars: B, $\mathrm{D}=100 \mu \mathrm{m}, \mathrm{C}, \mathrm{E}-\mathrm{J}=20 \mu \mathrm{m}, \mathrm{K}-\mathrm{L}=5 \mu \mathrm{m}$ 

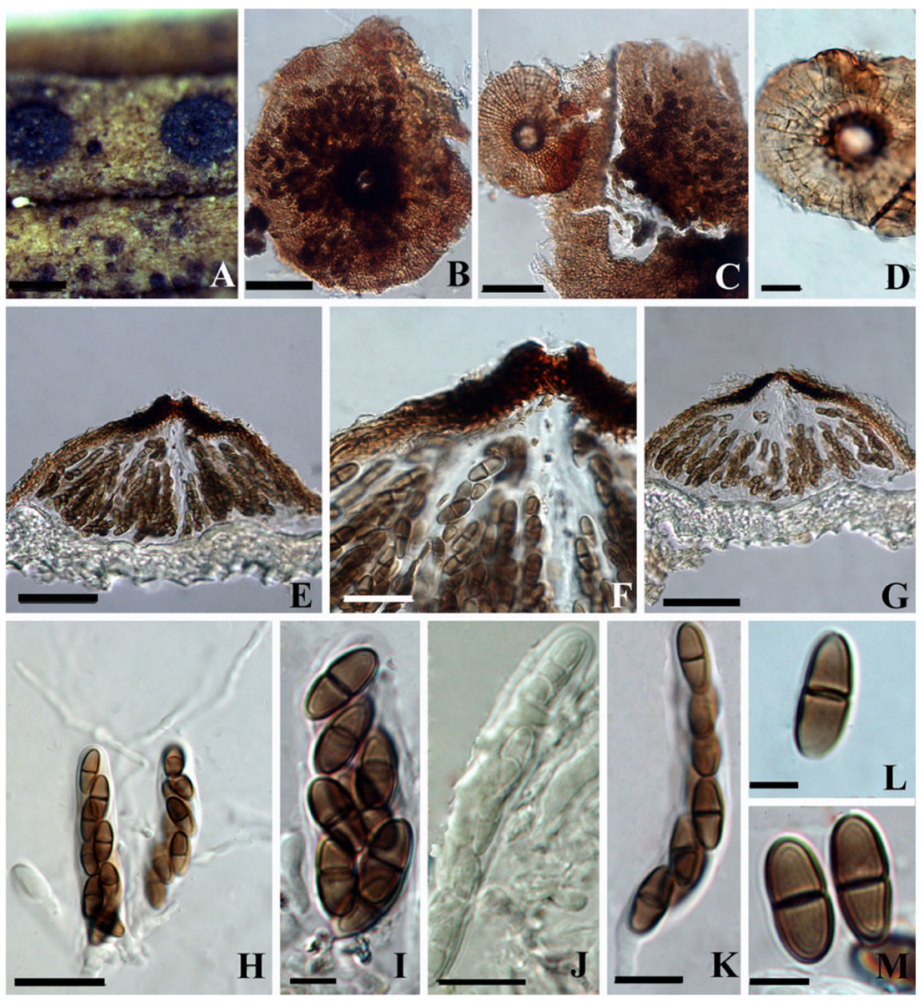

Fig. 4. Arnaudiella caronae (PDD 54414)

a Habit, appearance of ascomata on the host surface. b, $\mathbf{c}, \mathbf{d}$ Squash mount of ascoma. Note the scutate structure and radiating arrangement of hypha. $\mathbf{e}-\mathbf{g}$ Section of an ascoma. Note the peridium and $\mathrm{F}$ note ostiole. $\mathbf{h}-\mathbf{k}$ Ascus Note with a pedicel and pseudoparaphyses in Melzer's reagent. L, M. Ascospores. Scale bars: A=500 $\mu \mathrm{m}, \mathrm{B}, \mathrm{C}, \mathrm{E}, \mathrm{G}=50 \mu \mathrm{m}, \mathrm{D}, \mathrm{J}, \mathrm{K}=10$ $\mu \mathrm{m}, \mathrm{F}, \mathrm{H}=20 \mu \mathrm{m}, \mathrm{I}, \mathrm{L}, \mathrm{M}=5 \mu \mathrm{m}$ 

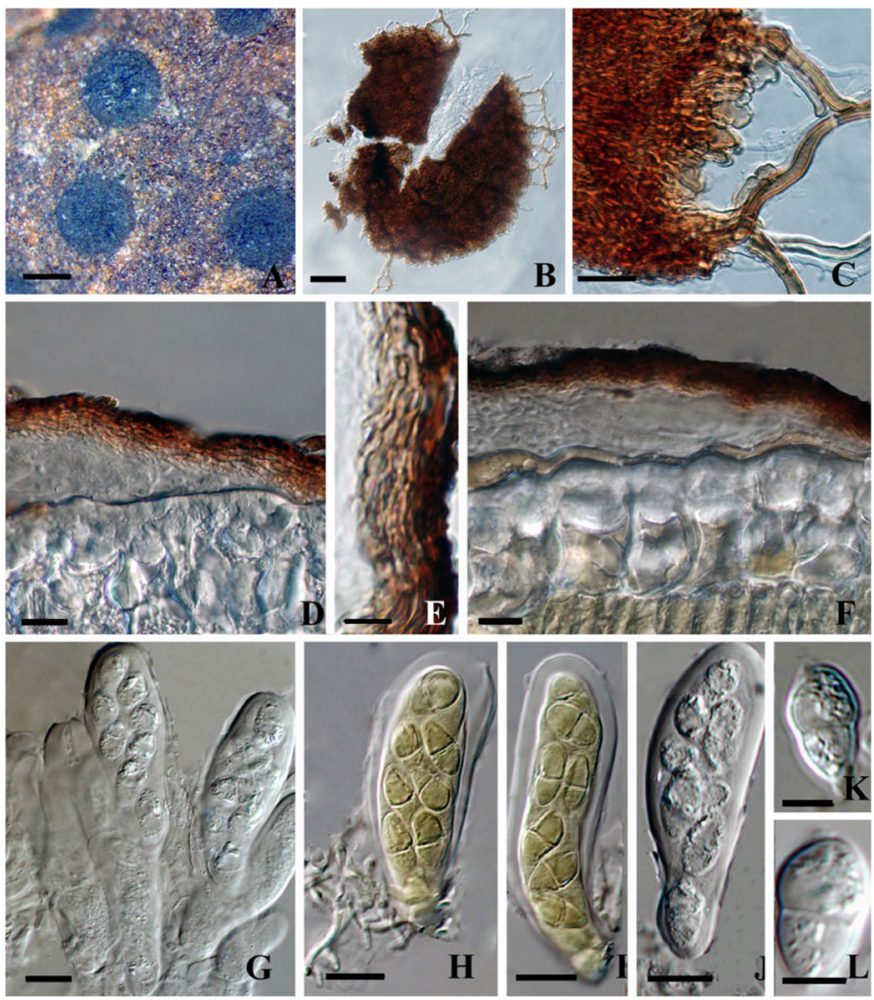

Fig. 5. Calothyriopsis conferta (holotype)

a Appearance of colony and ascomata on the host surface. $\mathbf{b}, \mathbf{c}$ Squash mount of ascoma. Note superficial mycelium. d-f Section of ascoma. Note the peridium which comprises two layers of cells. g, h Hamathecium. Note pseudoparaphyses. $\mathbf{i}-\mathbf{j}$ Asci. Note mounted in Melzer's reagent. $\mathbf{k}-\mathbf{l}$ Ascospores. Scale bars: A=500 $\mu \mathrm{m}, \mathrm{B}-\mathrm{D}, \mathrm{F}-\mathrm{J}=10 \mu \mathrm{m}, \mathrm{E}, \mathrm{K}, \mathrm{L}=5 \mu \mathrm{m}$ 

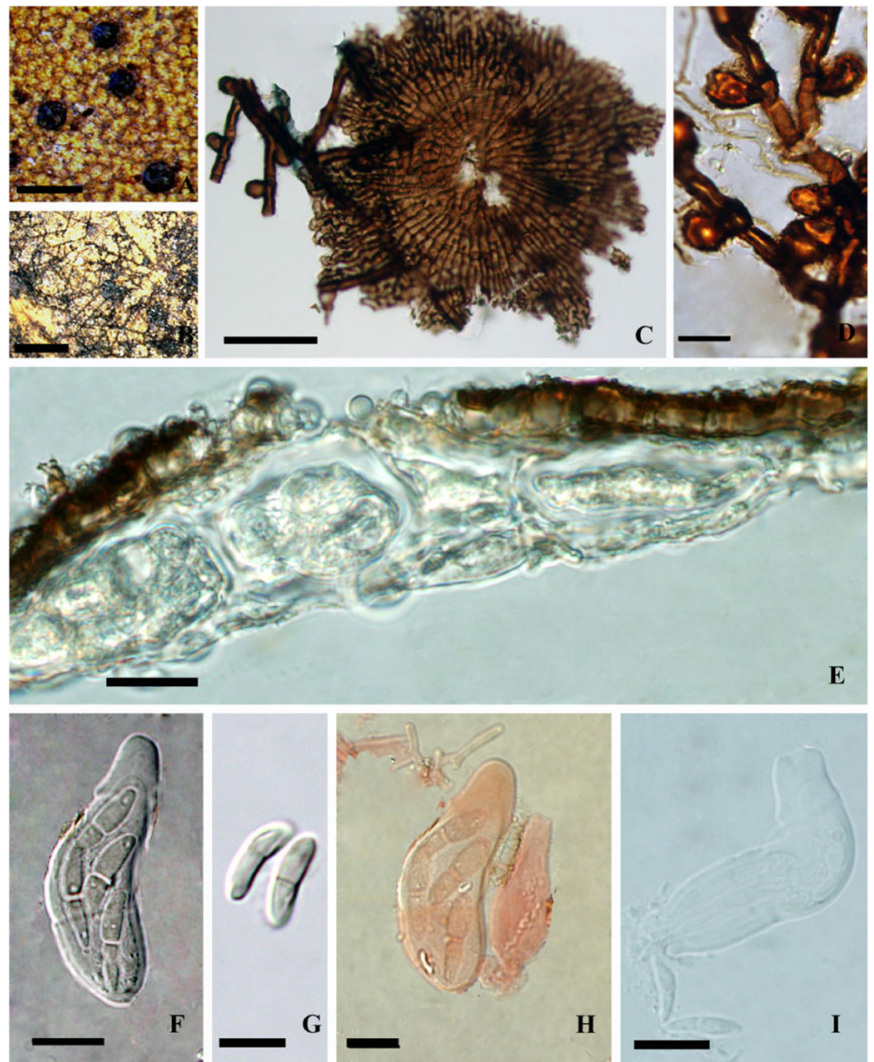

Fig. 6. Caribaeomyces tetrasporus (isotype, BPI 698559B)

a, b Appearance of colony and ascomata on the host surface. c Squash mount of ascomata. Note radiating arranged cells of the thyriothecium. C. Ascoma. Note radiating cells of the thyriothecium. d Hyphopodia. E. Section of ascoma. Note the peridium. f, h Asci. Note mature asci in Congo red. g, i Ascospores. Scale bars: A, B=200 $\mu \mathrm{m}, \mathrm{C}=20 \mu \mathrm{m}, \mathrm{D}-\mathrm{I}=10 \mu \mathrm{m}$ 

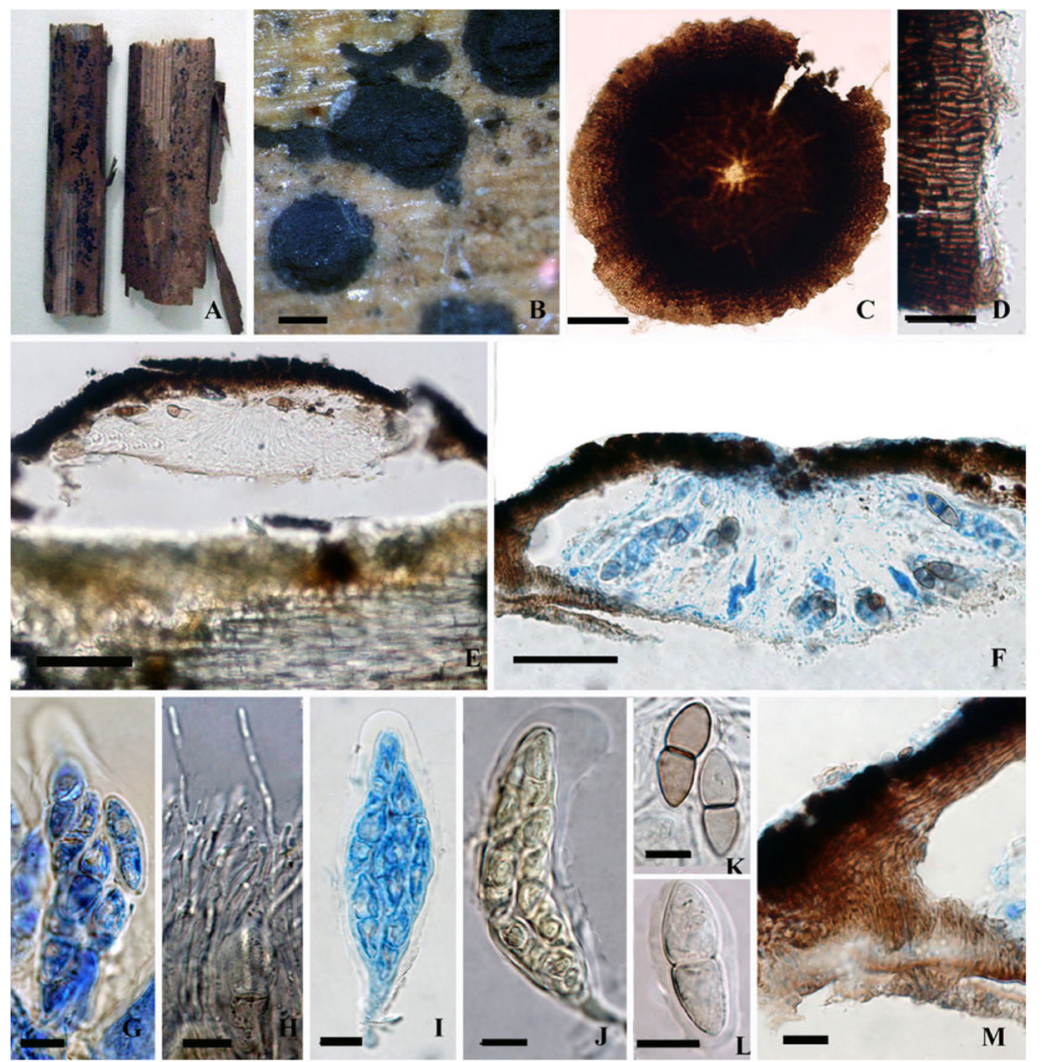

Fig. 7. Palawania grandis (holotype)

a Appearance of fungi body against on the stem. b Appearance of colony and ascomata on the host surface. $\mathbf{c}, \mathbf{d}$ Squash mount of ascoma. e, $\mathbf{f}, \mathbf{m}$ Section of ascoma. Note the Peridium and Hamathecium. g, i, j Asci. k, l Ascospores. Note ascospores with sheath. Scale bars: $\mathrm{B}=500 \mu \mathrm{m}, \mathrm{C}-\mathrm{F}=20 \mu \mathrm{m}, \mathrm{G}-\mathrm{M}=10 \mu \mathrm{m}$ 

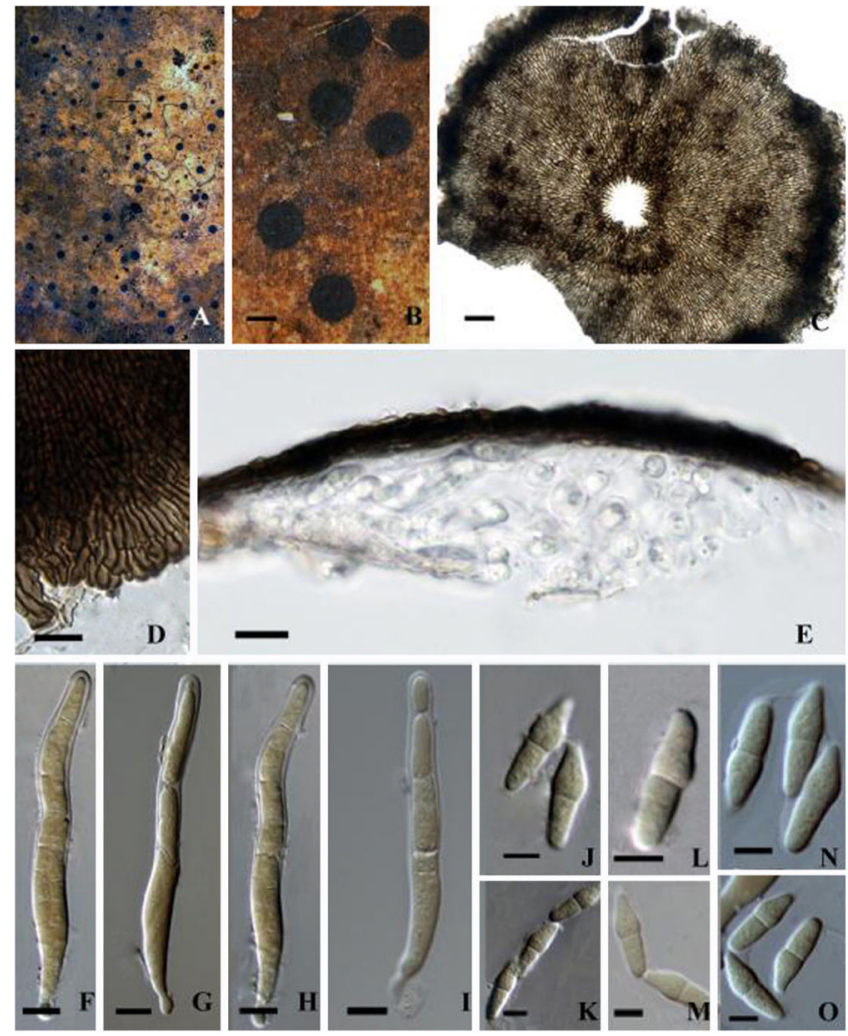

Fig. 8. Paramicrothyrium chinensis (holotype)

a Habitat. b Ascomata on the upper surface of leaves. c, $\mathbf{d}$ Squash mount of ascoma. e The section of ascomata. $\mathbf{f}-\mathbf{i}$ Asci with 8 -spored. $\mathbf{j}-\mathbf{o}$ Ascospores. Scale bars: $\mathrm{B}=200 \mu \mathrm{m}, \mathrm{C}=20$ $\mu \mathrm{m}, \mathrm{D}-\mathrm{I}=10 \mu \mathrm{m}, \mathrm{J}-\mathrm{O}=5 \mu \mathrm{m}$ 


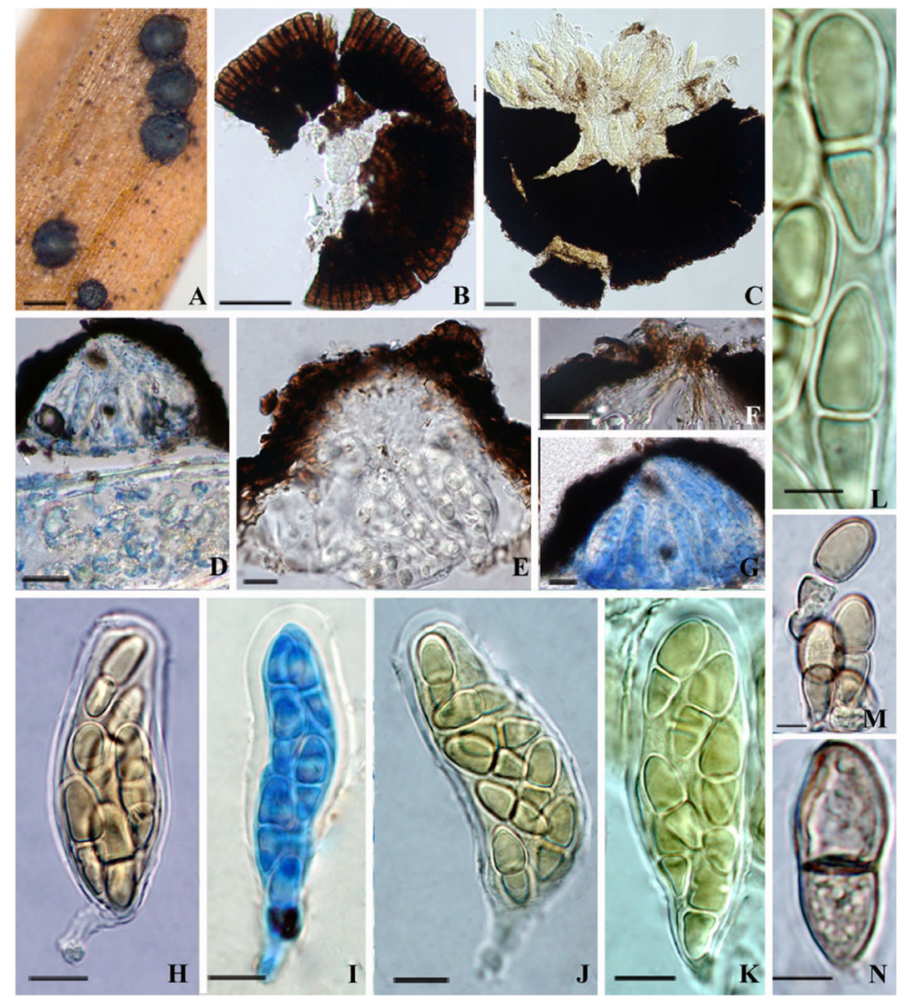

Fig. 9. Seynesiella juniperi (syntype)

a Habit, appearance of ascomata on the host surface. b, $\mathbf{c}$ Squash mount of ascoma. Note the scutate structure and radiating arrangement of hypha. $\mathbf{d}-\mathbf{g}$ Section of an ascoma. Note the peridium and F note ostiole. $\mathbf{h}-\mathbf{k}$ Ascus Note with a pedicel and pseudoparaphyses in Melzer's reagent and blue cotton's reagent. I-n Ascospores. Note the slightly constricted septum and the upper cell wider than the lower cell and light brown when matured. Scale bars: $\mathrm{A}=200 \mu \mathrm{m}, \mathrm{B}, \mathrm{C}, \mathrm{G}=20 \mu \mathrm{m}, \mathrm{D}=40 \mu \mathrm{m}, \mathrm{E}, \mathrm{F}, \mathrm{H}-\mathrm{K}=10 \mu \mathrm{m}, \mathrm{L}-\mathrm{N}=5 \mu \mathrm{m}$ 

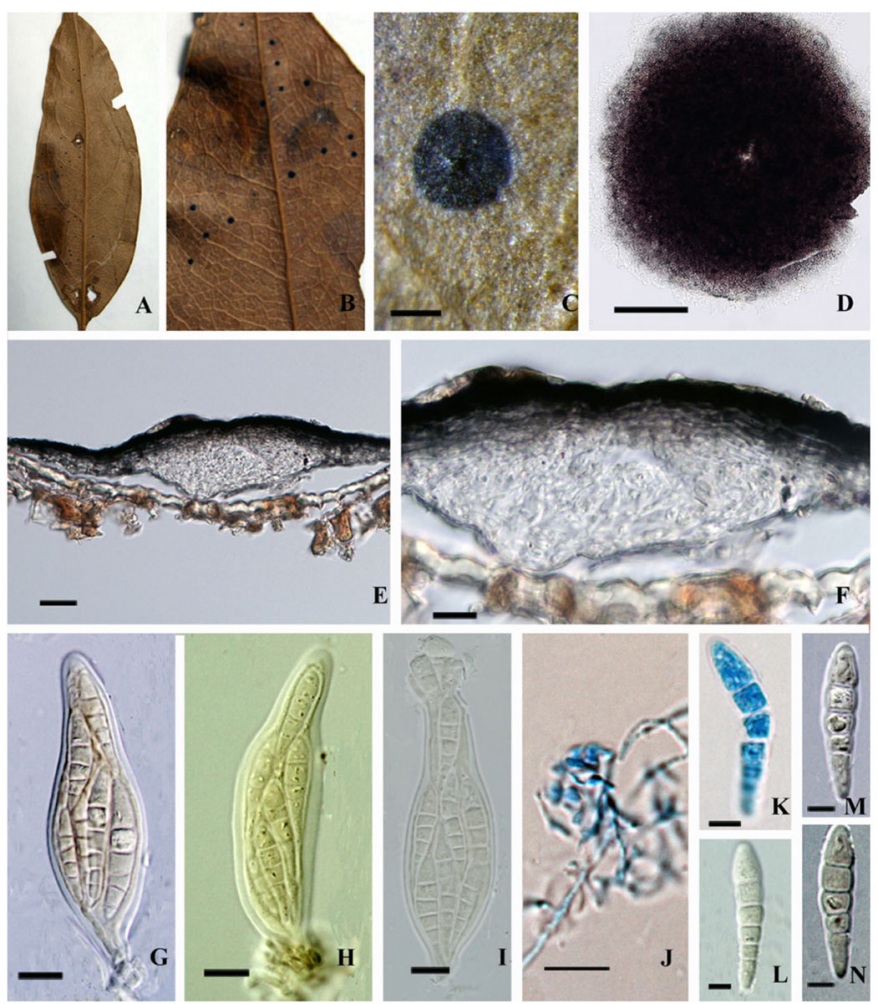

Fig. 10. Micropeltis applanata (lectotype)

a Habit of fungus. b, c. Appearance of ascomata on the host surface. d Squash mount of ascoma. e, $\mathbf{f}$ Section of ascoma. Note the peridium. $\mathbf{g}-\mathbf{i}$ Asci. $\mathbf{j}$ Pseudoparaphyses in a gelatinous matrix. $\mathbf{k}-\mathbf{n}$ Ascospores. Scale bars: $\mathrm{C}=200 \mu \mathrm{m}, \mathrm{D}=50 \mu \mathrm{m}, \mathrm{E}=20 \mu \mathrm{m}, \mathrm{G}-\mathrm{J}=10$ $\mu \mathrm{m}, \mathrm{K}-\mathrm{N}=5 \mu \mathrm{m}$ 

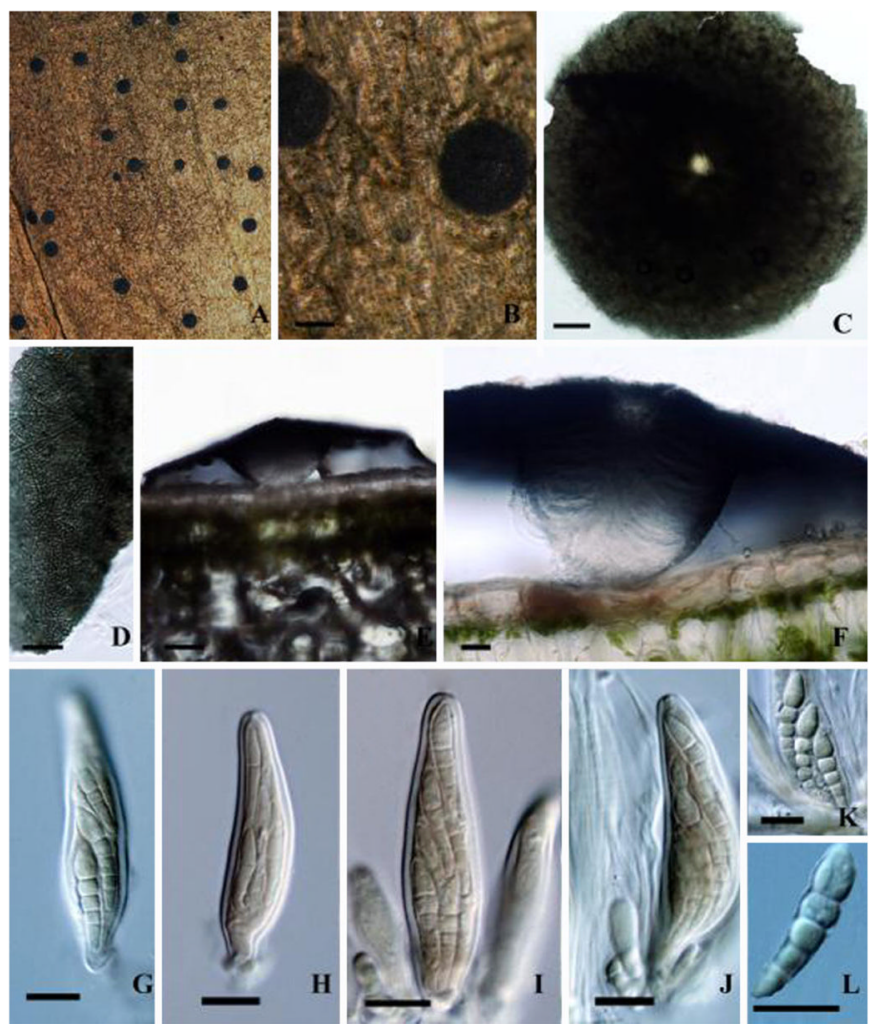

Fig. 11. Micropeltis zingiberacicola (holotype)

a Habitat of substrate. b Ascomata on the lower surface of leaves. c, d Squash mount of ascoma. e, $\mathbf{f}$ The section of ascomata. $\mathbf{g}-\mathbf{j}$ Asci with 8-spored. $\mathbf{k ,} \mathbf{l}$ Ascospores. Scale bars: $\mathrm{B}=200 \mu \mathrm{m}, \mathrm{C}, \mathrm{E}=50 \mu \mathrm{m}, \mathrm{D}, \mathrm{F}=20 \mu \mathrm{m}, \mathrm{G}-\mathrm{L}=10 \mu \mathrm{m}$ 

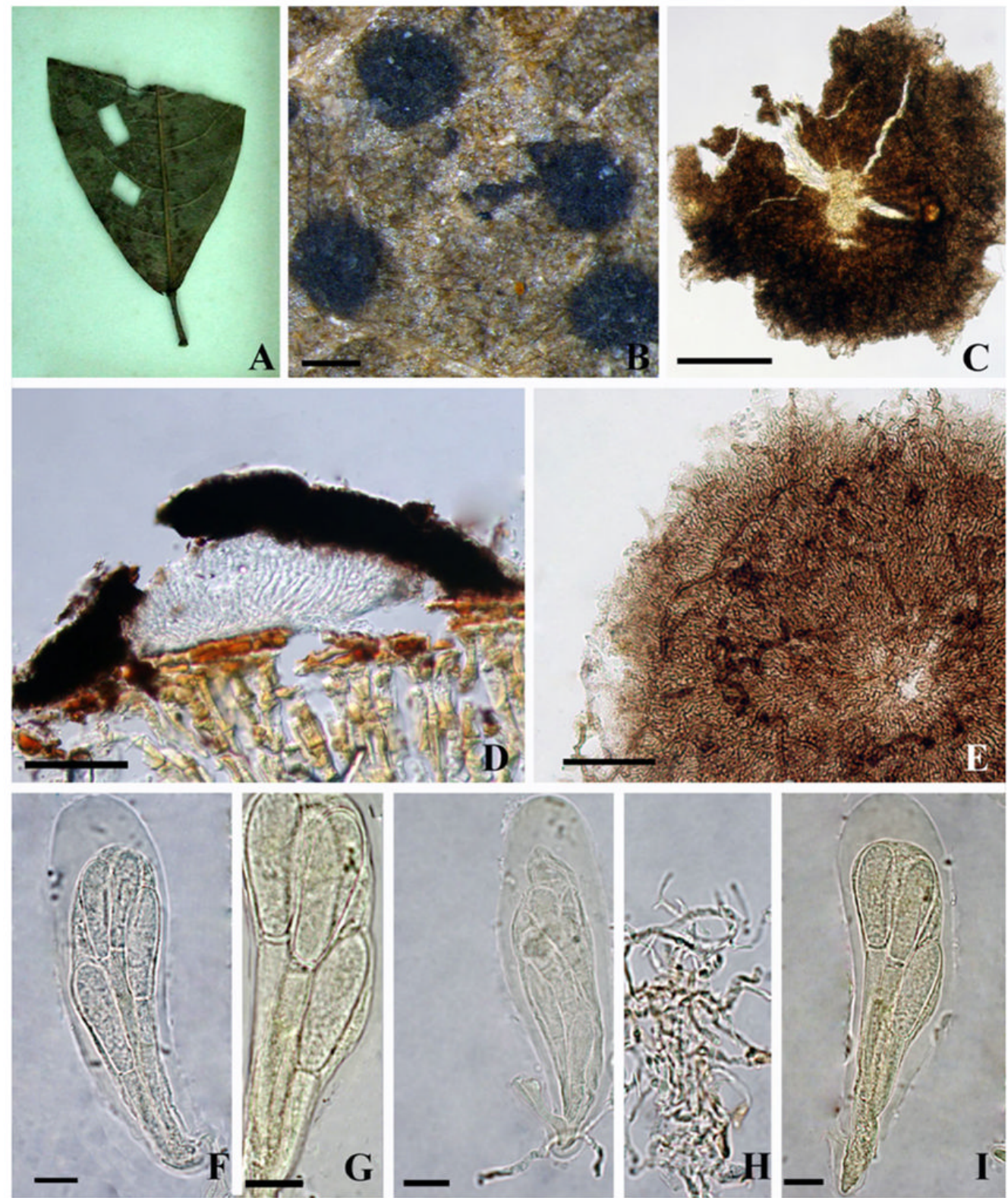

Fig. 12. Byssopeltis maranhensis (holotype)

a Appearance of fungi body on surface of leaf. $\mathbf{b}$ Appearance of colony and ascomata on the host surface. c, e Squash mount of ascoma. d Section of ascoma. Note the peridium which comprises one layer of cells. f, $\mathbf{h}, \mathbf{i}$ Asci. Note mounted in Melzer's reagent and pseudoparaphyses. g Ascospores Note G. Ascospores become yellow to light brown in Melzer's reagent. Scale bars: B=500 $\mu \mathrm{m}, \mathrm{C}=50 \mu \mathrm{m}, \mathrm{D}, \mathrm{E}=20 \mu \mathrm{m}, \mathrm{F}-\mathrm{I}=10 \mu \mathrm{m}$ 

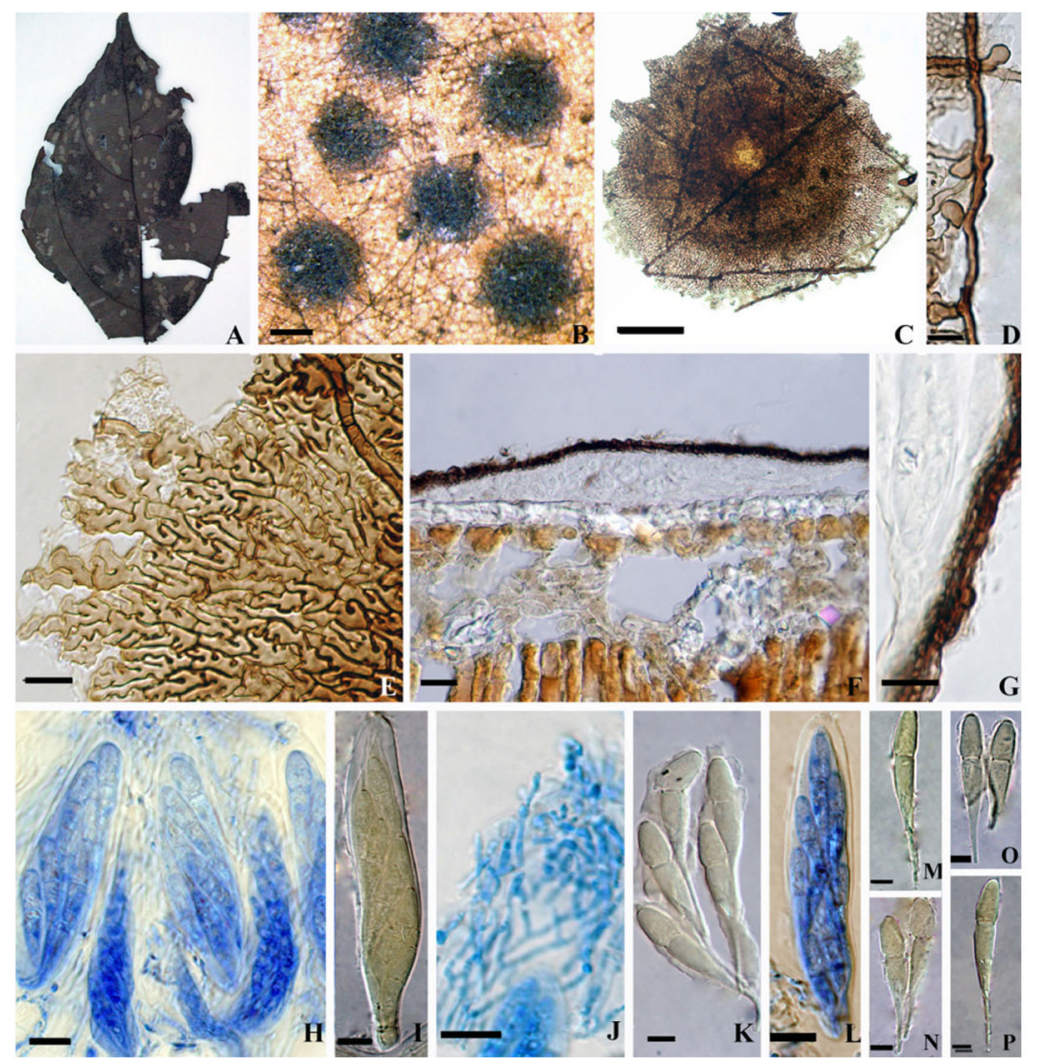

Fig. 13. Caudella oligotricha (holotype)

a Appearance of fungi body against on surface of leaf. $\mathbf{b}$ Appearance of colony and ascomata on the host surface. c, e Squash mount of ascoma. $\mathbf{d}$ Hyphopodia. f, $\mathbf{g}$ Section of ascoma. Note the peridium which comprises one layer of cells. H, J. Hamathecium. Note paraphyses. i, I Asci. k, m-p Ascospores. Note with caudate. Scale bars: B=500 $\mu \mathrm{m}, \mathrm{C}, \mathrm{F}=$ $20 \mu \mathrm{m}, \mathrm{D}, \mathrm{E}, \mathrm{G}-\mathrm{J}=10 \mu \mathrm{m}$. K, M-P=5 $\mu \mathrm{m}$ 

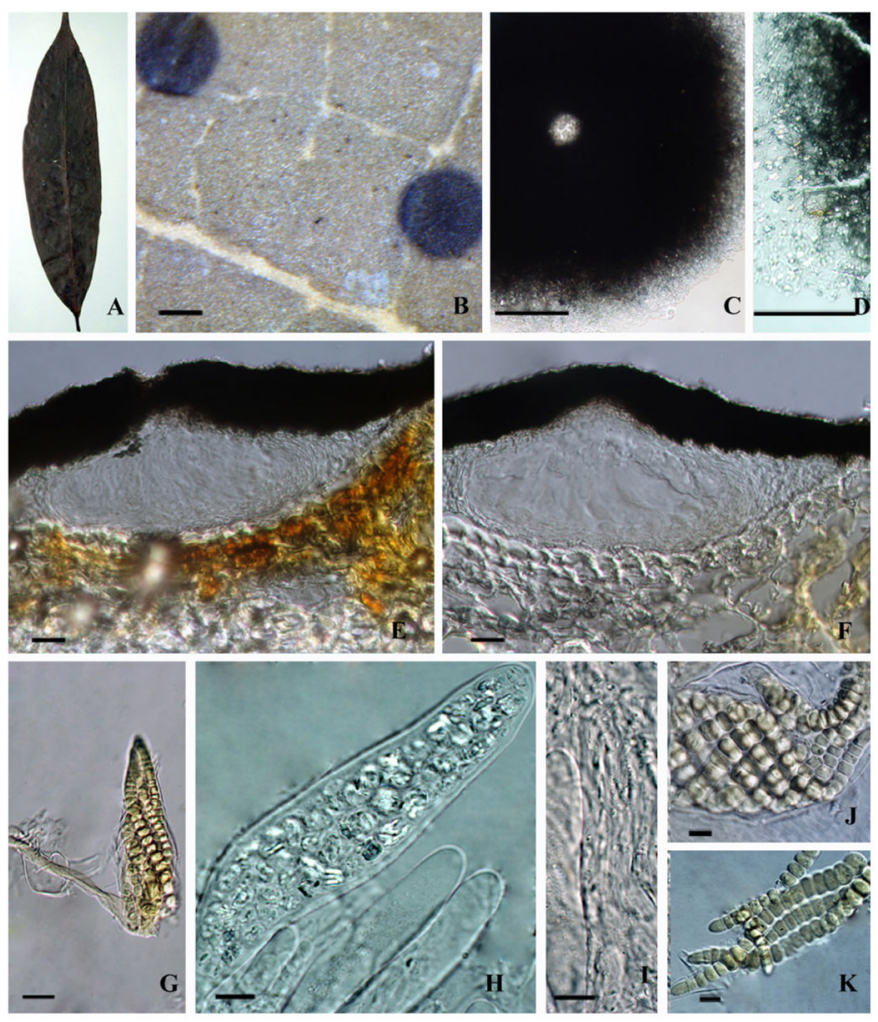

Fig. 14. Scolecopeltidium mirabile (NY 2021)

a, b Appearance of ascomata on the host surface. $\mathbf{c}, \mathbf{d}$ Squash mount of ascoma. e, $\mathbf{f}$ Section of ascoma. $\mathbf{g}, \mathbf{h}$ Asci. j, $\mathbf{k}$ Ascospores. Note the numerous septa. i Pseudoparaphyses. Scale bars: $\mathrm{B}=500 \mu \mathrm{m}, \mathrm{C}=50 \mu \mathrm{m}, \mathrm{D}, \mathrm{G}=20 \mu \mathrm{m}, \mathrm{E}, \mathrm{F}=20 \mu \mathrm{m}, \mathrm{H}-\mathrm{K}=10 \mu \mathrm{m}$ 

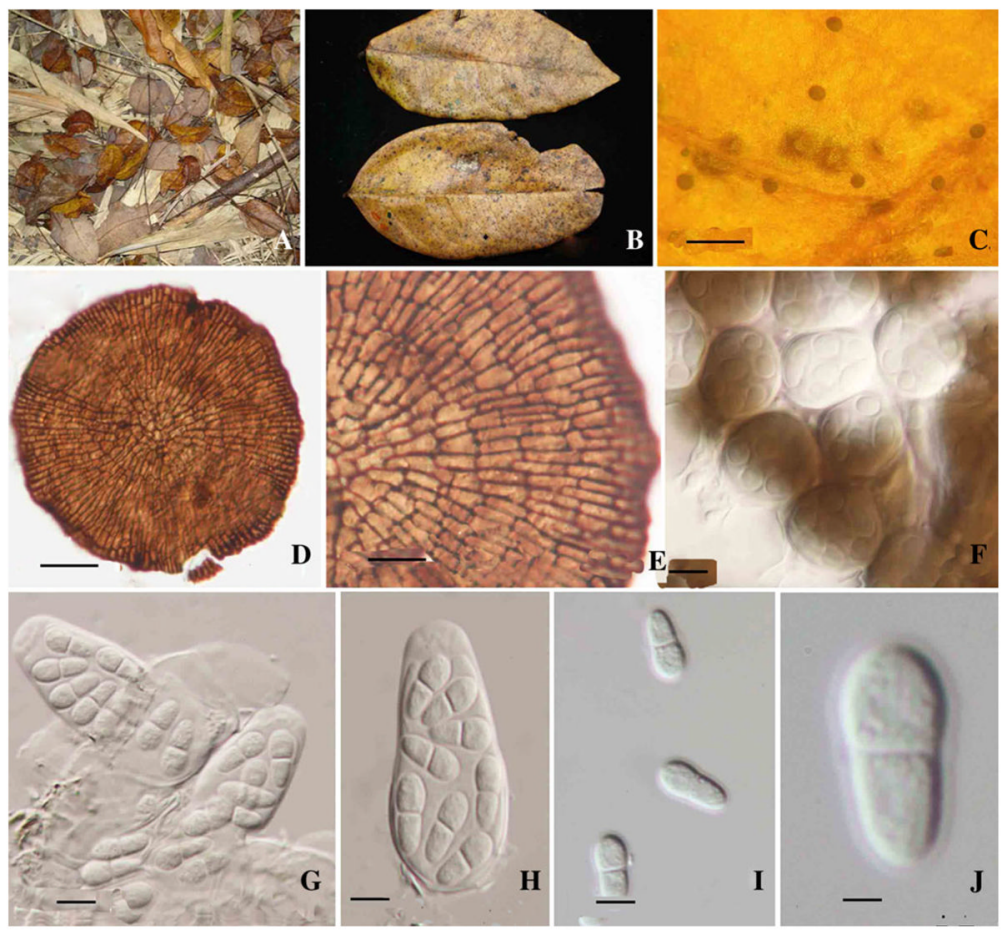

Fig. 15. Neomicrothyrium siamense (holotype)

a Habitat of substrate. b, c Ascomata forming on surface and lower surface of leaves. d, $\mathbf{e}$ Squash mount of ascoma and close-up of peridium. $\mathbf{f}-\mathbf{h}$ Asci with 8-spored. Note while asci are together will be globose or subglobose, when they are separated become clavate tovoid or subglobose shape. $\mathbf{i}, \mathbf{j}$ Ascospores surrounded with sheath. Scale bars: $\mathrm{C}-\mathrm{E}=100 \mu \mathrm{m}, \mathrm{F}-$ $\mathrm{H}=10 \mu \mathrm{m}, \mathrm{I}-\mathrm{J}=5 \mu \mathrm{m}$ 

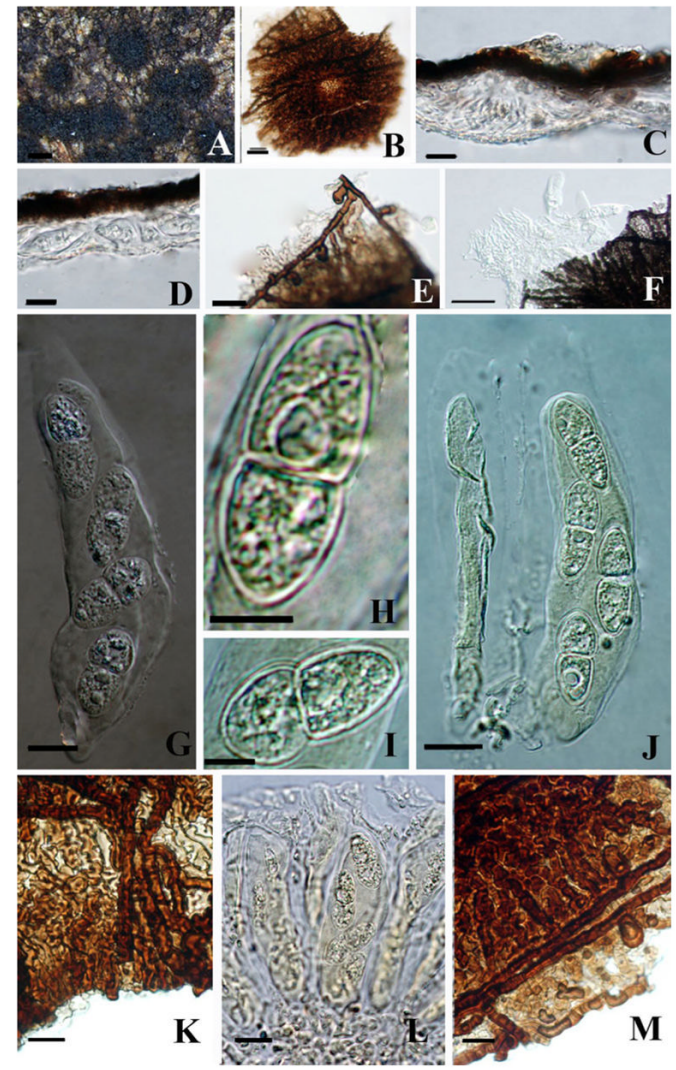

Fig. 16. Asterinema caseariae (holotype)

a Habit, appearance of ascomata on the host surface. $\mathbf{b}, \mathbf{k}, \mathbf{m}$ Squash mount of Thyriothecia. Note comprised of radially irregularly arranged cells. c, $\mathbf{d}$ Section of Thyriothecia Note the peridium. e Hyphopodia and mycelium. f, I Hamathecium. Note the pseudoparaphyses $\mathbf{g}, \mathbf{j}$ Ascus. Note short pedicel in Melzer's reagent. h, i Ascospores. Note the slightly constricted septum. Scale bars: A=200 $\mu \mathrm{m}, \mathrm{B}, \mathrm{E}, \mathrm{F}=20 \mu \mathrm{m}, \mathrm{C}, \mathrm{D}, \mathrm{G}, \mathrm{J}, \mathrm{K}, \mathrm{L}, \mathrm{M}=10 \mu \mathrm{m}, \mathrm{H}, \mathrm{L}=5 \mu \mathrm{m}$ 

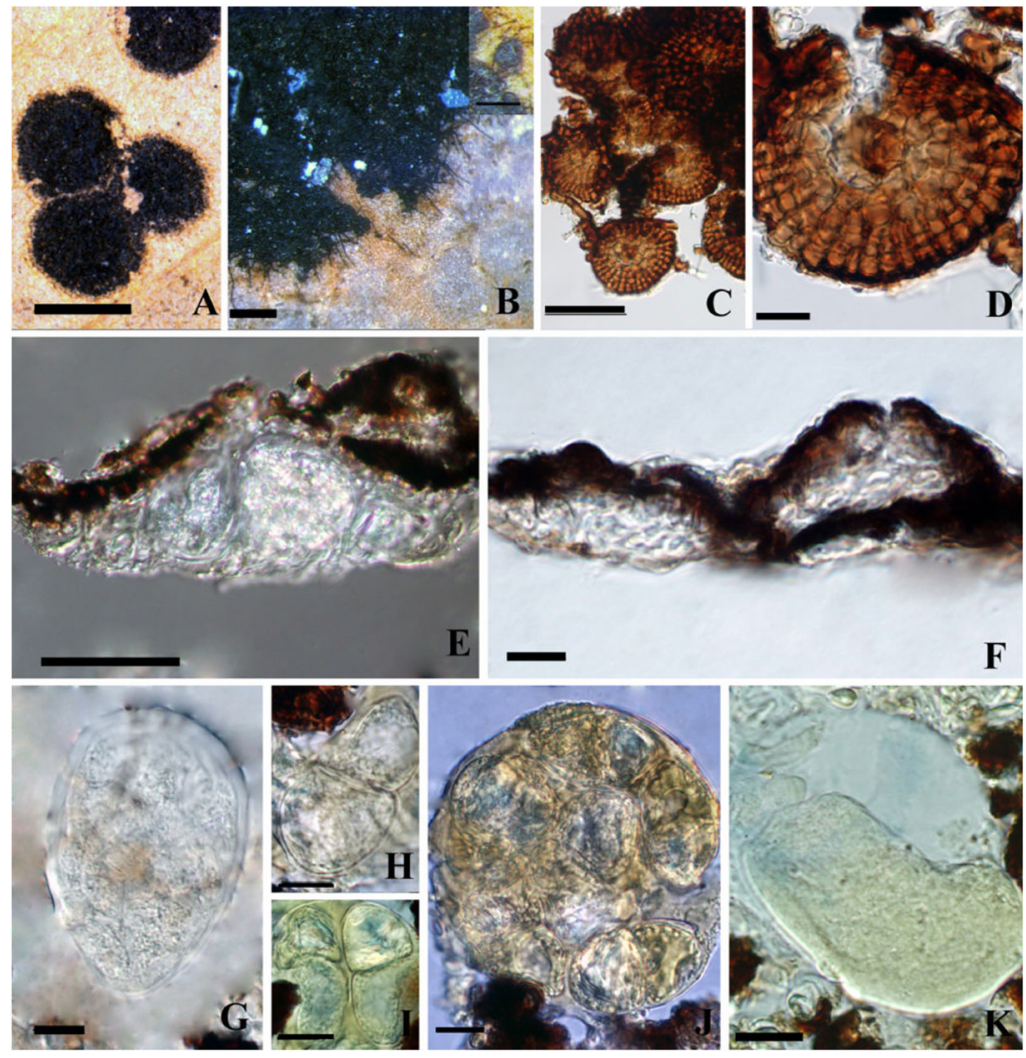

Fig. 17. Govindua shoreae (holotype)

a Appearance of fungi body against on surface of leaf. $\mathbf{b}$ Appearance of colony and ascomata on the host surface. $\mathbf{c}, \mathbf{d}$ Squash mount of ascoma. e, f Section of ascoma. Note the peridium which comprises one layer of cells. $\mathbf{g}, \mathbf{j}$, $\mathbf{k}$ Asci. Note mounted in Melzer's reagent and ocular chamber. $\mathbf{h}, \mathbf{i}$ Ascospores Note G. Ascospores become yellow to light brown in Melzer's regant. Scale bars: $A=1200 \mu \mathrm{m}, \mathrm{B}=500 \mu \mathrm{m}, \mathrm{C}=200 \mu \mathrm{m}, \mathrm{D}, \mathrm{F}=50 \mu \mathrm{m}, \mathrm{E}, \mathrm{G}-\mathrm{I}=10$ $\mu \mathrm{m}$ 

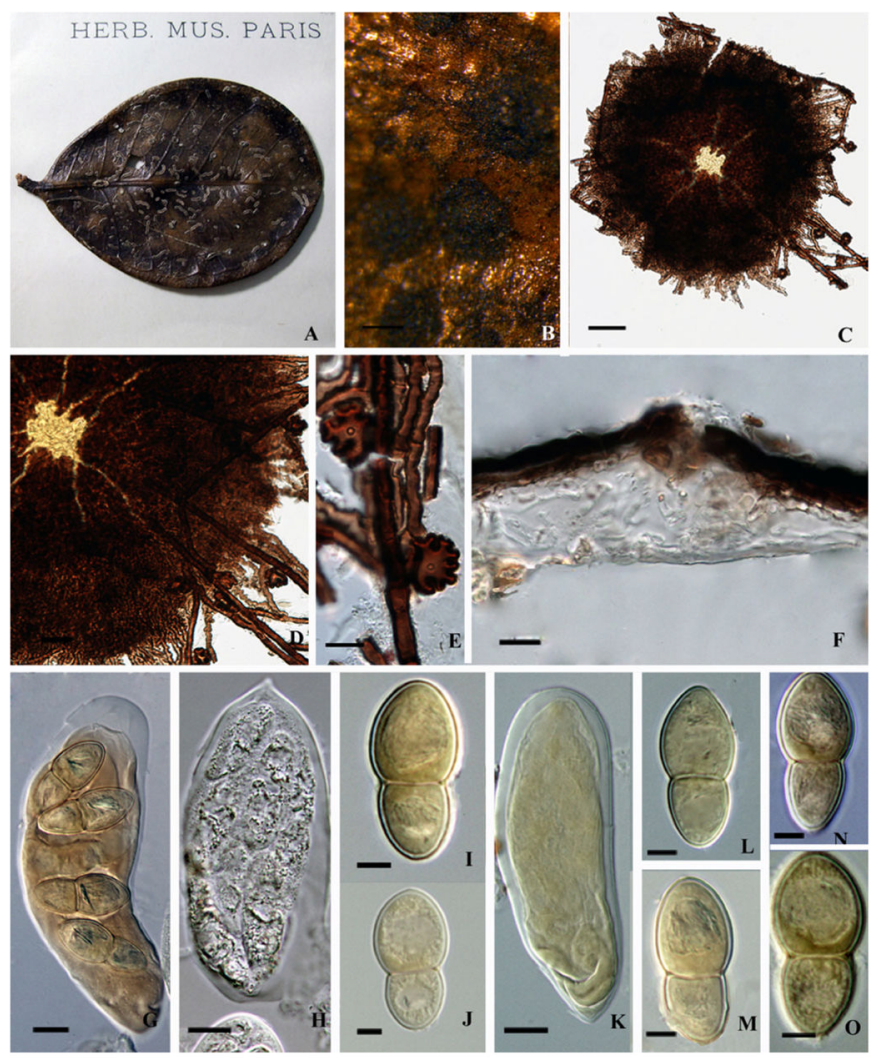

Fig. 18. Maublancia myrtacearum (holotype)

a, b Appearance of fungi body on lower surface of leaf. c, $\mathbf{d}$ Squash mount of ascoma. Note $\mathrm{D}$ the crack pore. e Superficial hyphae with hyphopodia. $\mathbf{f}$ Section of ascoma. Note the peridium which comprises one layer of cells; $\mathbf{g}, \mathbf{h}, \mathbf{k}$ Asci. Note G, K mounted in Melzer's reagent. i, j, l-o Ascospores. Note round at the ends, with smooth-walled. Scale bars: $B=200$ $\mathrm{C}=50 \mu \mathrm{m}, \mathrm{D}=20 \mu \mathrm{m}, \mathrm{E}-\mathrm{H}, \mathrm{K}=10 \mu \mathrm{m}, \mathrm{I}, \mathrm{J}, \mathrm{L}-\mathrm{O}=5 \mu \mathrm{m}$ 

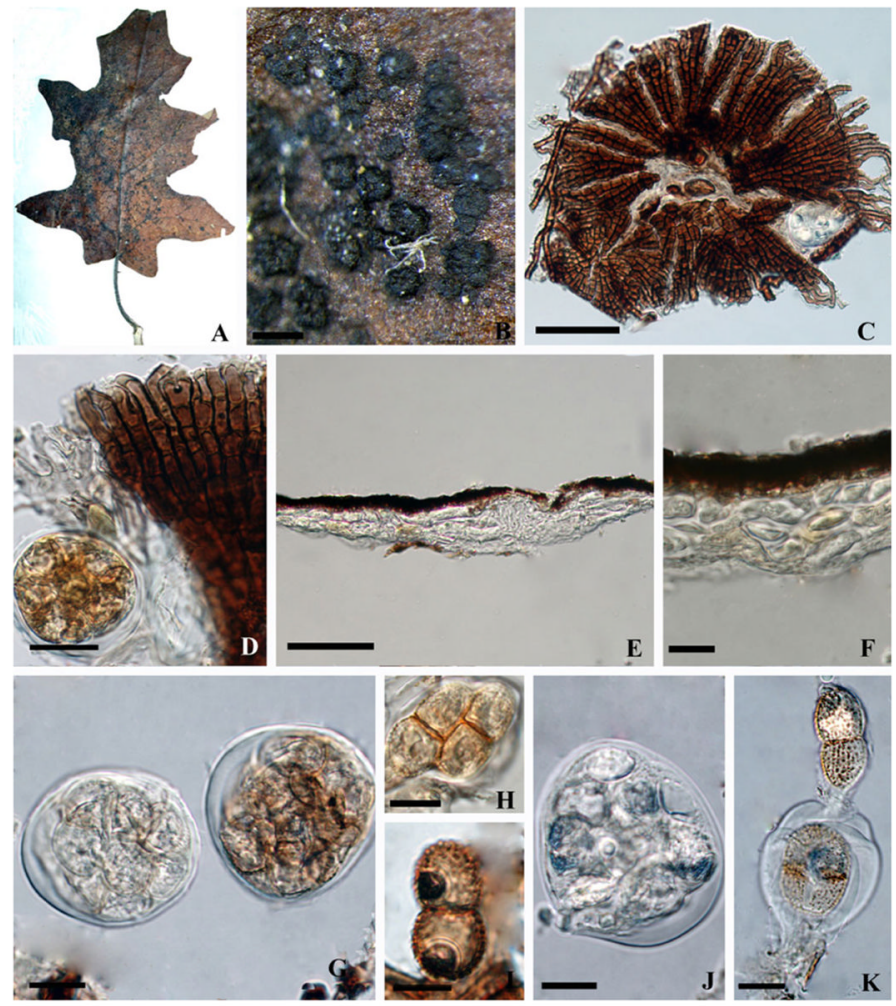

Fig. 19. Polycyclinopsis solani (holotype)

a Appearance of fungi body against on surface of leaf. b Appearance of colony and ascomata on the host surface. c, $\mathbf{d}$ Squash mount of ascoma. e, f Section of ascoma. Note the peridium which comprises one layer of cells. $\mathbf{g}, \mathbf{j}$ Asci. h, i, $\mathbf{k}$ Ascospores. Scale bars: $\mathrm{B}=500 \mu \mathrm{m}, \mathrm{C}, \mathrm{E}=50 \mu \mathrm{m}, \mathrm{D}, \mathrm{F}-\mathrm{K}=10 \mu \mathrm{m}$ 

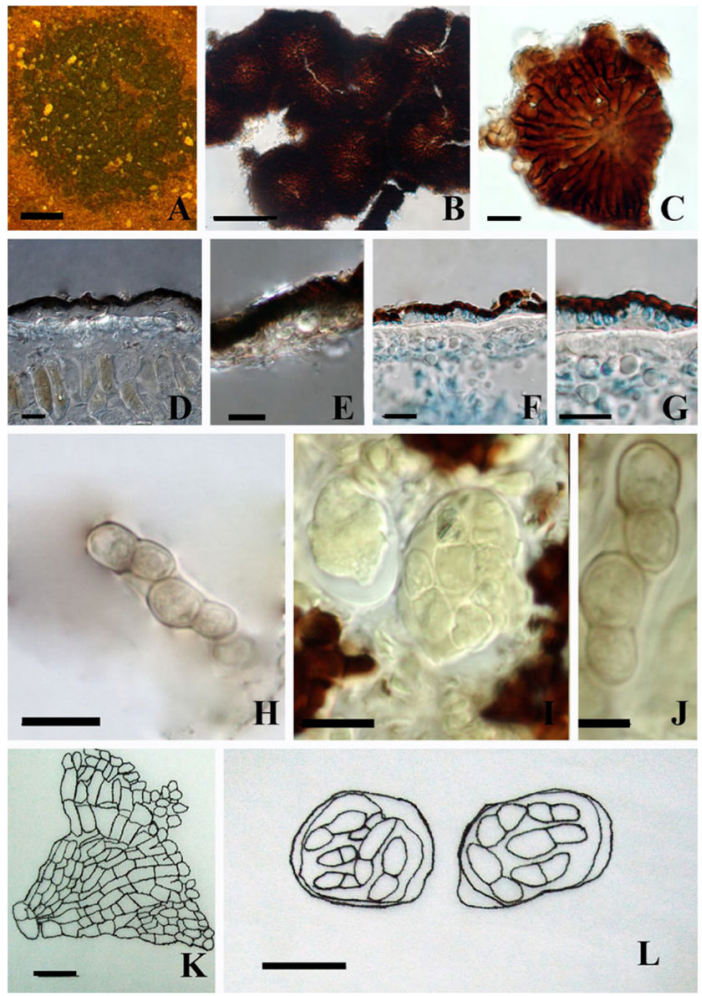

Fig. 20. Resendea paraguayensis(holotype)

a Appearance of colony and ascomata on the host surface. b Squash mount of ascomata. Note stellate cracking when squashed. c Ascoma. Note radiating cells of the thyriothecium. $\mathbf{d}-\mathbf{g}$ Section of ascoma. Note the peridium and $\mathbf{f}, \mathbf{g}$ mount in cotton blue reagent. $\mathbf{i}$ Asci. Note mature asci in Melzer's reagent. $\mathbf{h}, \mathbf{j}$ Ascosores. $\mathbf{k}, \mathbf{I}$ Draw a part of thyriothecium and asci. Scale bars: $\mathrm{A}=200 \mu \mathrm{m}, \mathrm{B}=20 \mu \mathrm{m}, \mathrm{C}-\mathrm{I}=10 \mu \mathrm{m}, \mathrm{J}=5 \mu \mathrm{m}$ 

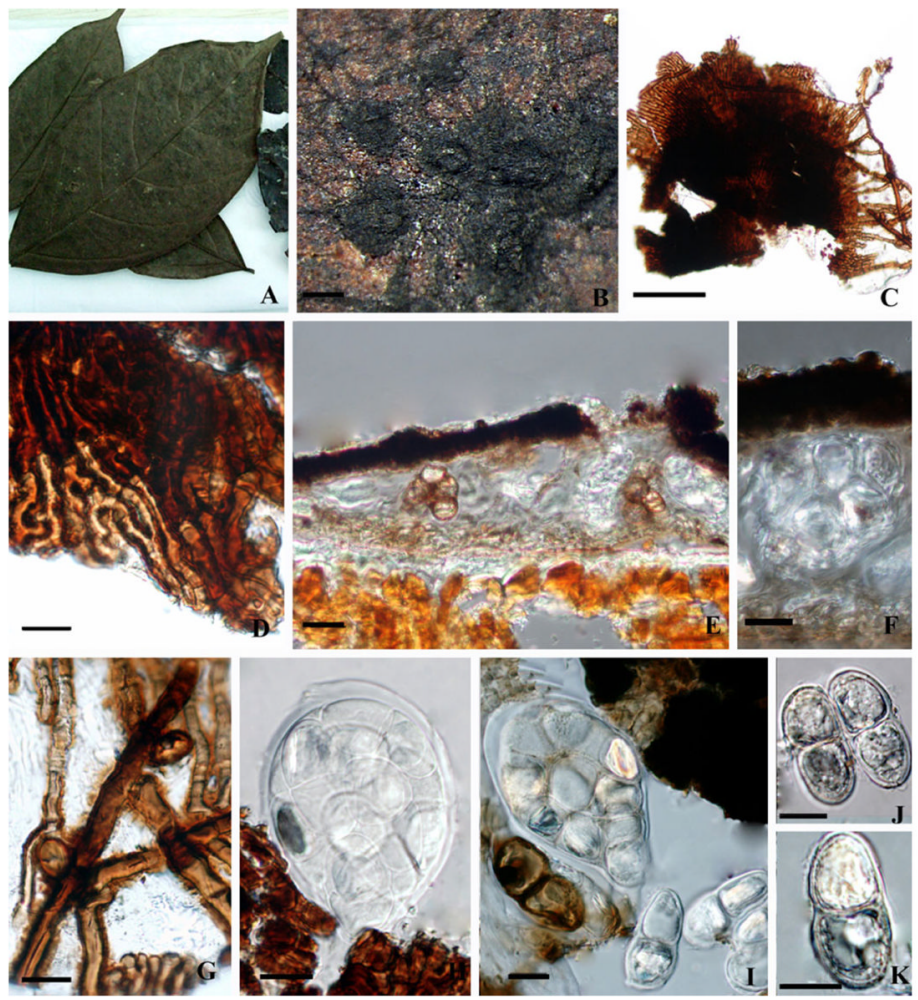

Fig. 21. Trichopeltospora pipericola (holotype)

a Appearance of fungi body against on surface of leaf. $\mathbf{b}$ Appearance of colony and ascomata on the host surface. $\mathbf{c}, \mathbf{d}$ Squash mount of ascoma. e, f Section of ascoma. Note the peridium which comprises one layer of cells. $\mathbf{g}$ Hyphopodia. $\mathbf{h}, \mathbf{i}$ Asci. $\mathbf{j}, \mathbf{k}$ Ascospores.

Scale bars: $\mathrm{B}=200 \mu \mathrm{m}, \mathrm{C}, \mathrm{E}=20 \mu \mathrm{m}, \mathrm{D}, \mathrm{F}-\mathrm{K}=10 \mu \mathrm{m}$ 

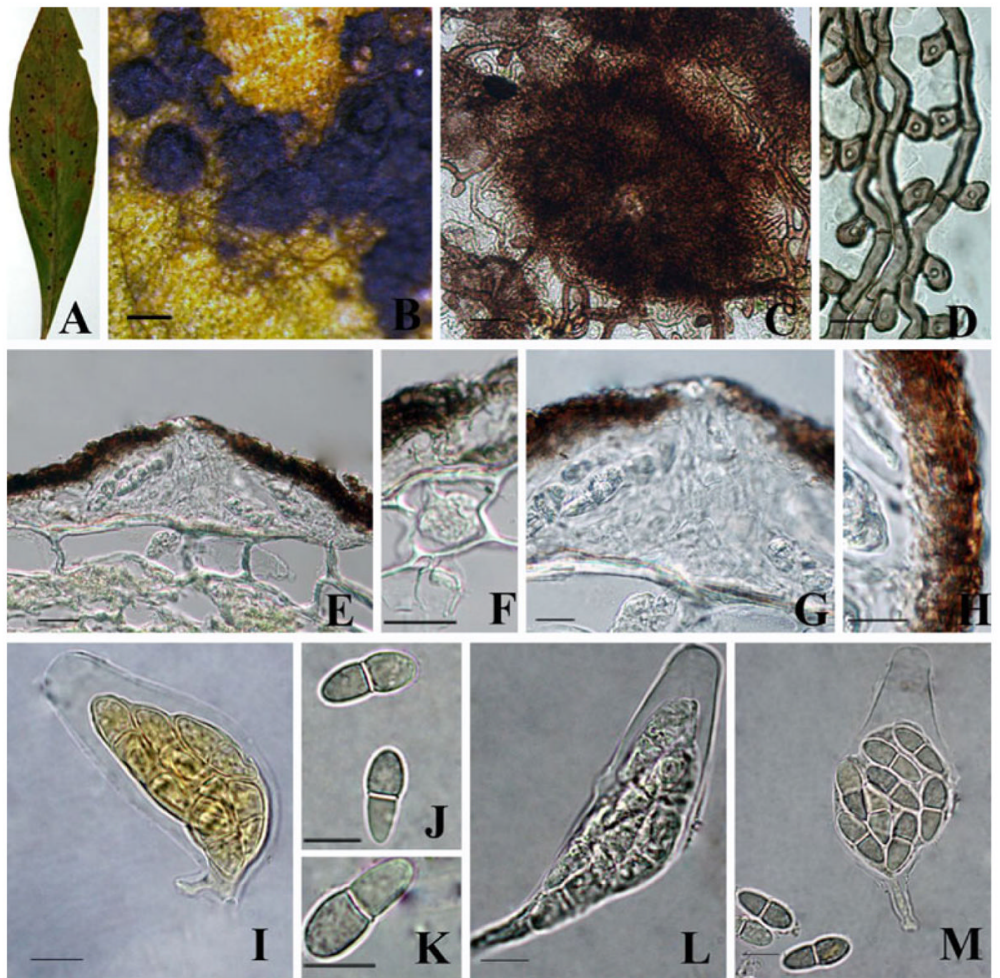

Fig. 22. Xenostomella tovarensis (holotype)

a, b Appearance of ascomata on the host surface. $\mathbf{c}$ Squash mount of superficial hyphae and ascoma. d Hyphopodia. e-h Section of ascoma. Note F haustoria and $\mathrm{H}$ peridium. $\mathbf{i}, \mathbf{l}, \mathbf{m}$ Ascus Note the pedicel and large apical part which is thickened. $\mathbf{j}, \mathbf{k}$ Ascospores. Note the larger apical cell and basal cell which tapers in some spores. Scale bars: B=200 $\mu \mathrm{m}, \mathrm{C}, \mathrm{E}$, $\mathrm{F}=20 \mu \mathrm{m}, \mathrm{D}, \mathrm{G}-\mathrm{M}=10 \mu \mathrm{m}$ 

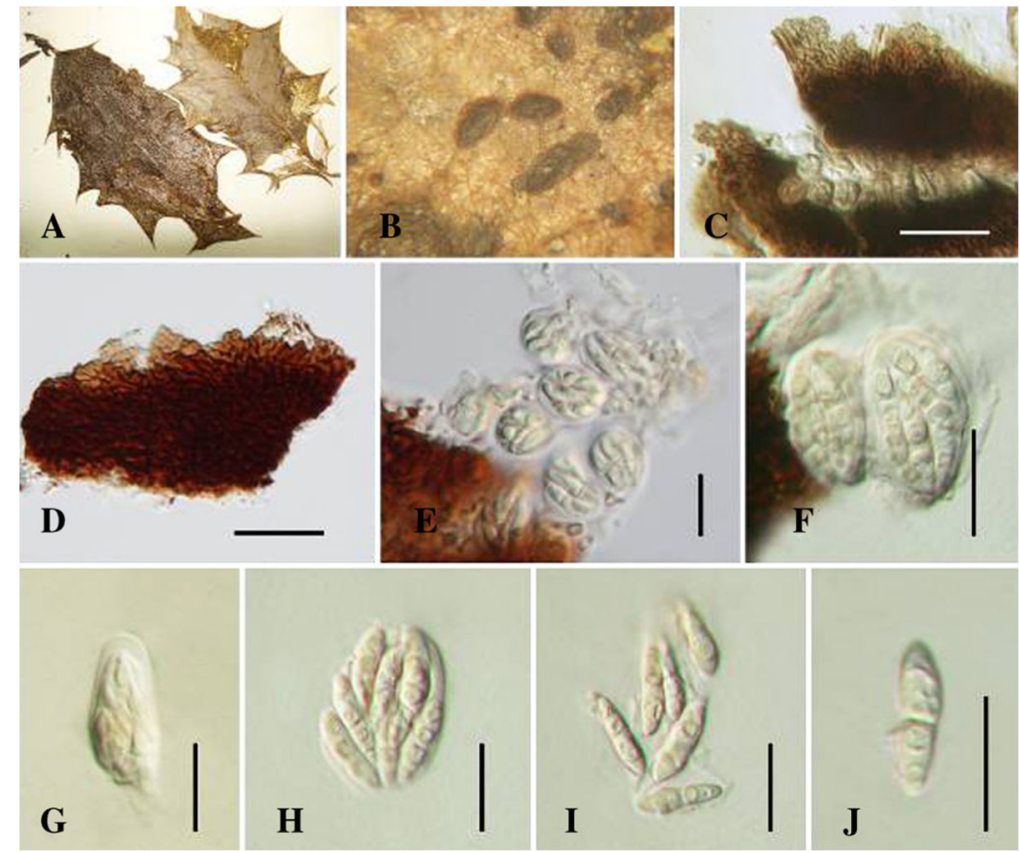

Fig. 23. Aulographum hederae (BR)

a, b Host and habit of ascomata on substrate. $\mathbf{c}, \mathbf{d}$ Squash of ascoma. e, $\mathbf{f}$ Squash of asci. $\mathbf{g}, \mathbf{h}$ Asci, G in Melzer's reagent. i; j. Ascospores with remnants of mucilage. Scale bars $=\mathrm{A}-$ $\mathrm{E}=50 \mu \mathrm{m}, \mathrm{F}-\mathrm{J}=10 \mu \mathrm{m}$ 

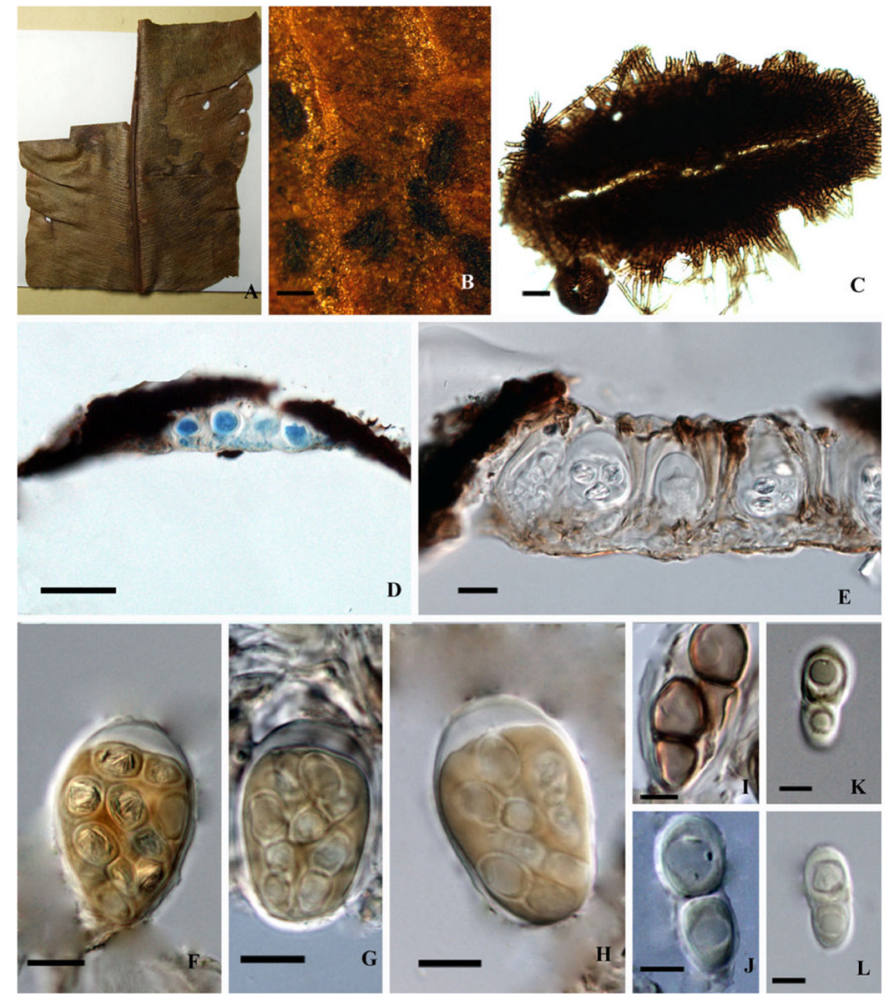

Fig. 24. Lembosiella polyspora (holotype)

a, b Appearance of colony and ascomata on the host surface. c Squash mount of ascoma. d, e Section of ascoma. Note the peridium, D in cotton blue. $\mathbf{f}-\mathbf{h}$ Asci. Note mounted in Melzer's reagent. i-l Ascospores. Note two-cell. Scale bars: B=200 $\mu \mathrm{m}, \mathrm{C}, \mathrm{D}=20 \mu \mathrm{m}, \mathrm{E}-$ $\mathrm{H}=10 \mu \mathrm{m}, \mathrm{I}-\mathrm{L}=5 \mu \mathrm{m}$ 

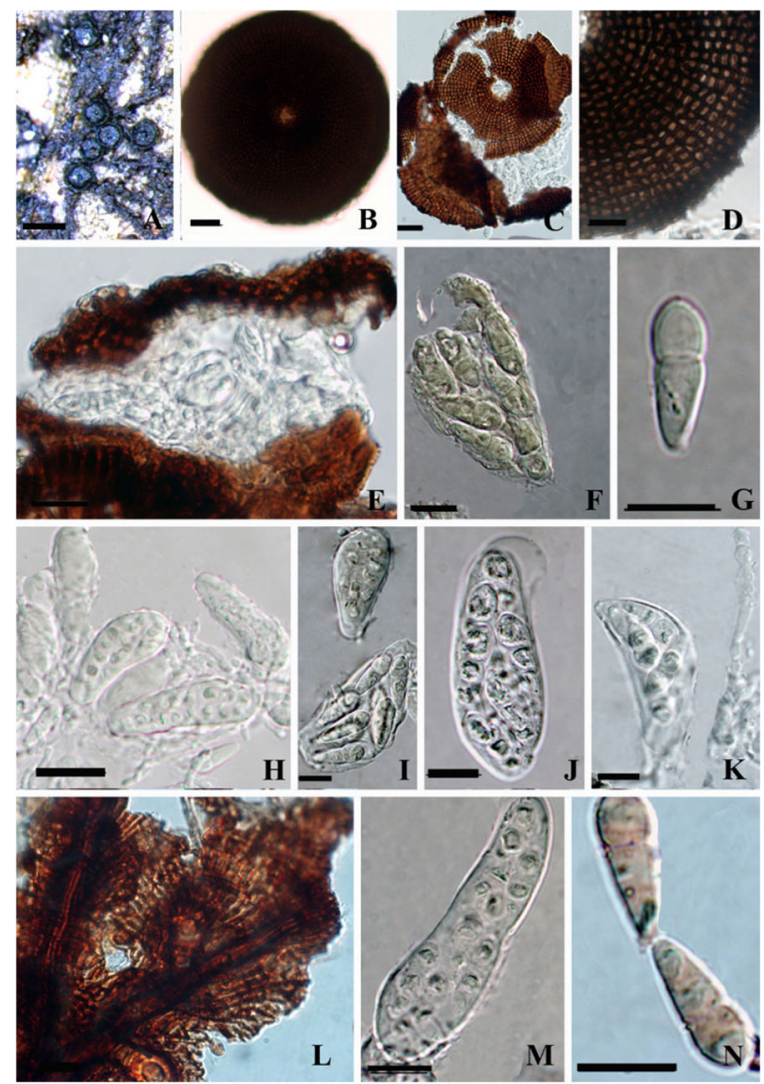

Fig. 25. Trichothyrium peristomalis (holotype of Actinopeltis peristomalis) a Habit, appearance of ascomata on the host surface. $\mathbf{b}, \mathbf{c}, \mathbf{d}$. Squash mount of ascoma. Note the parallel radiating arrangement of cells. E. Section of an ascoma. $\mathbf{f}, \mathbf{i}, \mathbf{j}, \mathbf{m}$ Ascus. $\mathbf{g}, \mathbf{n}$ Ascospores. Note the slightly constricted septum. H, K. Hamathecium. Note the pseudoparaphyses L. Superficial hyphae Note forming thalli. Scale bars: A=200 $\mu \mathrm{m}, \mathrm{B}, \mathrm{C}$, $\mathrm{I}=20 \mu \mathrm{m}, \mathrm{D}-\mathrm{N}=10 \mu \mathrm{m}$ 

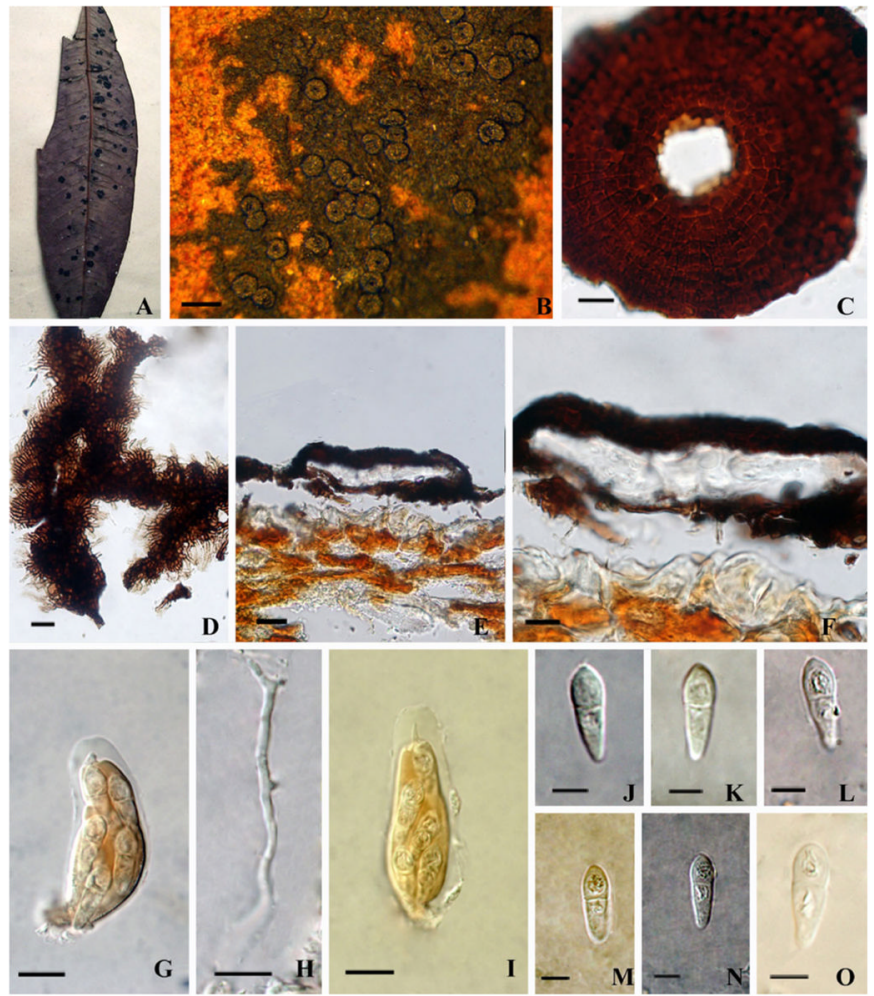

Fig. 26. Trichothyrium densum (holotype)

a, b Appearance of colony and ascomata on the host surface. $\mathbf{c}$ Squash mount of ascoma. d Superficial mycelium. Note forming thalli. e, $\mathbf{f}$ Section of ascoma. Note the peridium. $\mathbf{g}-\mathbf{i}$ Asci. Note I mounted in Melzer's reagent. $\mathbf{j}-\mathbf{o}$ Ascospores. Note two-cell with guttulas Scale bars: $\mathrm{B}=500 \mu \mathrm{m}, \mathrm{C}, \mathrm{D}, \mathrm{F}-\mathrm{I}=10 \mu \mathrm{m}, \mathrm{E}=20 \mu \mathrm{m}, \mathrm{J}-\mathrm{O}=5 \mu \mathrm{m}$ 

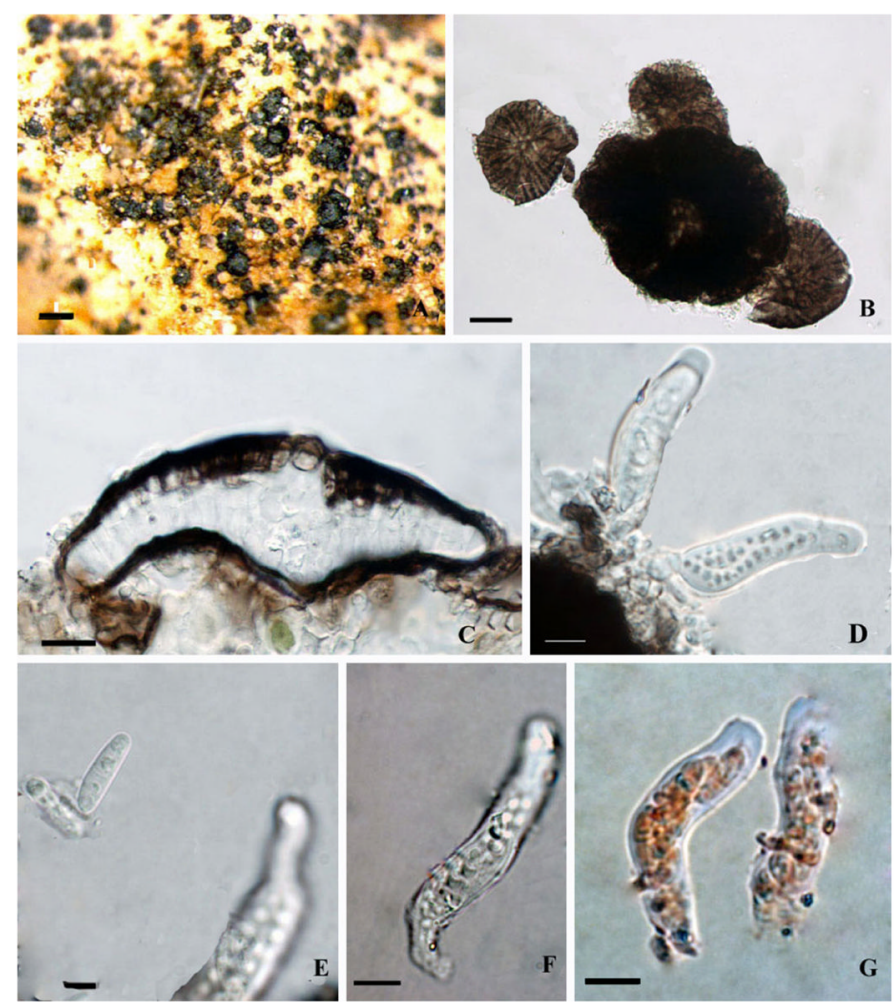

Fig. 27. Lichenopeltella maculan (isotype)

a Appearance of ascomata on the host surface. b Squash mount of ascoma. Note the thyrothecial radiating arrangement of cells. $\mathbf{c}$ Section of an ascoma. d, f Asci. Note Ascus with the pedicel. e Ascospore. $\mathbf{g}$ Inconspicuous apical structure of ascus in Congo red. Scale bars: $\mathrm{A}=200 \mu \mathrm{m}, \mathrm{B}=20 \mu \mathrm{m}, \mathrm{C}-\mathrm{G}=10 \mu \mathrm{m}$ 

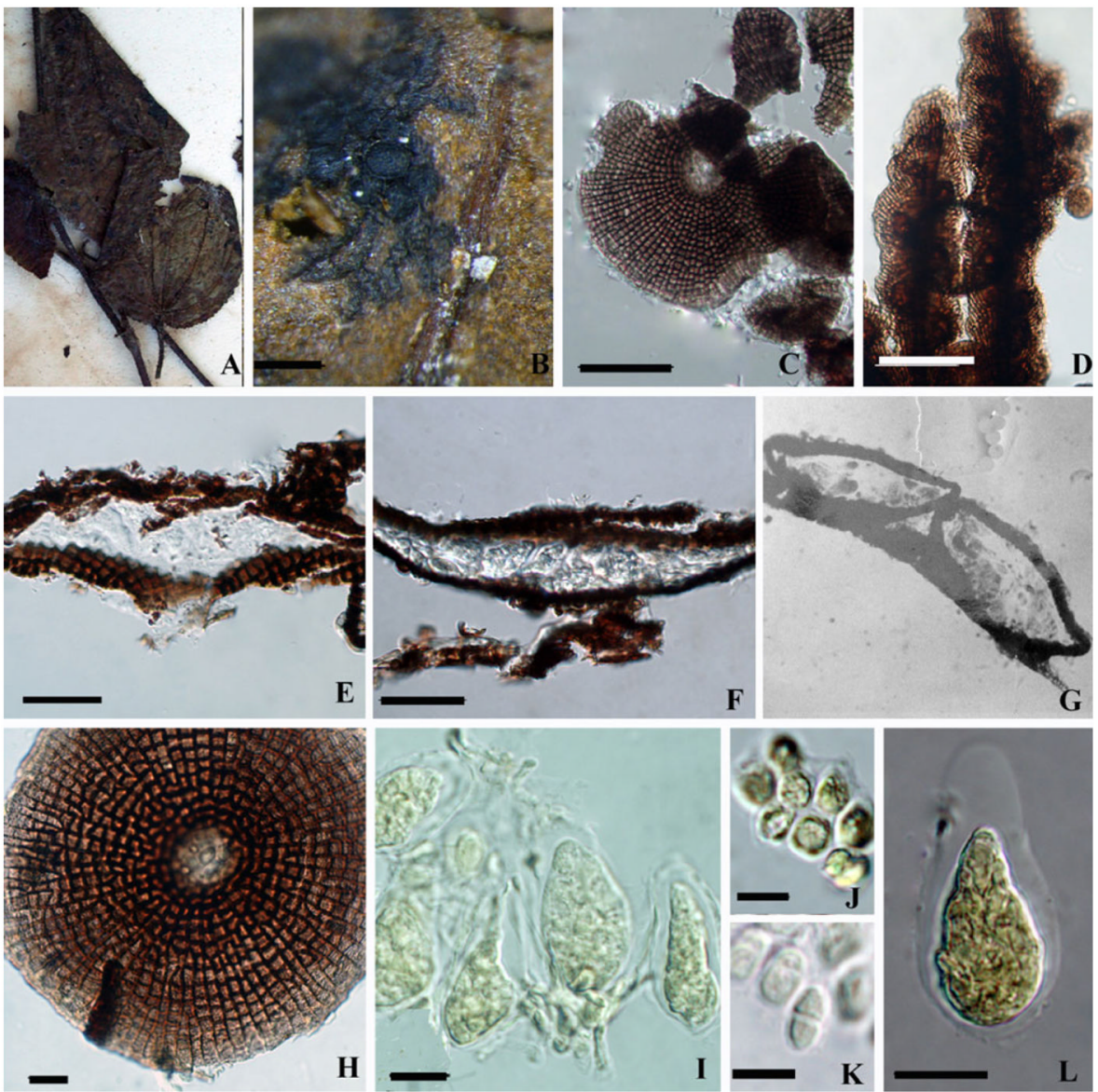

Fig. 28. Trichothyriomyces notatus (holotype)

a, b Appearance of fungus thallus on lower surface of leaf. $\mathbf{c}, \mathbf{h}$ Squash mount of ascoma. Note the radial structure. $\mathbf{e}-\mathbf{g}$ Section of ascoma. Note the peridium which comprises one layer of cells; $\mathbf{g}$ come from original photo. $\mathbf{d}$ superficial hyphae Note hyphae form thalli. i, $\mathbf{I}$ Asci. Note the sessile base and fissitunicate dehiscence. J, K. Ascospores. Scale bars: B=200 $\mu \mathrm{m}, \mathrm{C}, \mathrm{E}, \mathrm{F}=20 \mu \mathrm{m}, \mathrm{D}, \mathrm{H}-\mathrm{L}=10 \mu \mathrm{m}$ 

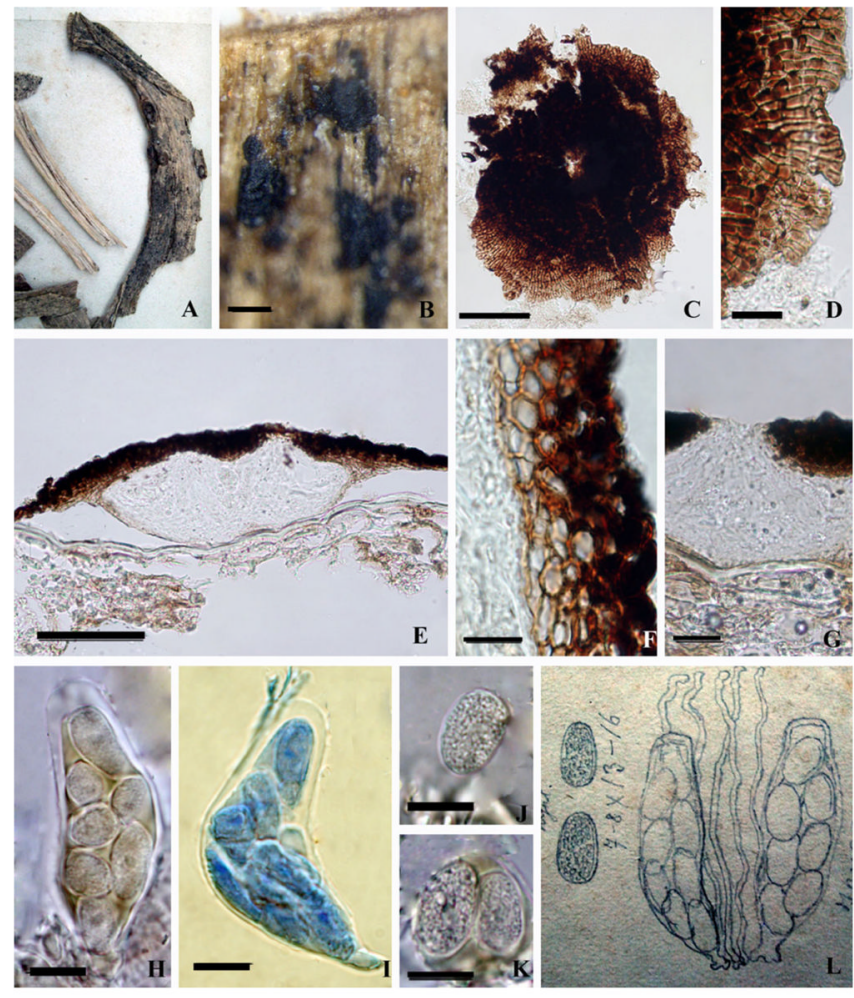

Fig. 29. Muyocopron corrientinuum (holotype)

a Appearance of ascomata on the host surface. b-d Squash mount of ascoma. e, $\mathbf{f}, \mathbf{h}$ Section of ascoma. Note the peridium which comprises two layers of cells and flattened ostiole. $\mathbf{i}$ Hamathecium. Note that the pseudoparaphyses are longer than asci. $\mathbf{j}, \mathbf{l}$ Asci mounted in blue cotton reagent. Note the bitunicate asci. $\mathbf{g}, \mathbf{k}$ Ascospores. Note guttules in ascospores. Scale bars: $\mathrm{A}=500 \mu \mathrm{m}, \mathrm{B}=50 \mu \mathrm{m}, \mathrm{C}-\mathrm{E}=20 \mu \mathrm{m}, \mathrm{F}-\mathrm{L}=10 \mu \mathrm{m}$ 

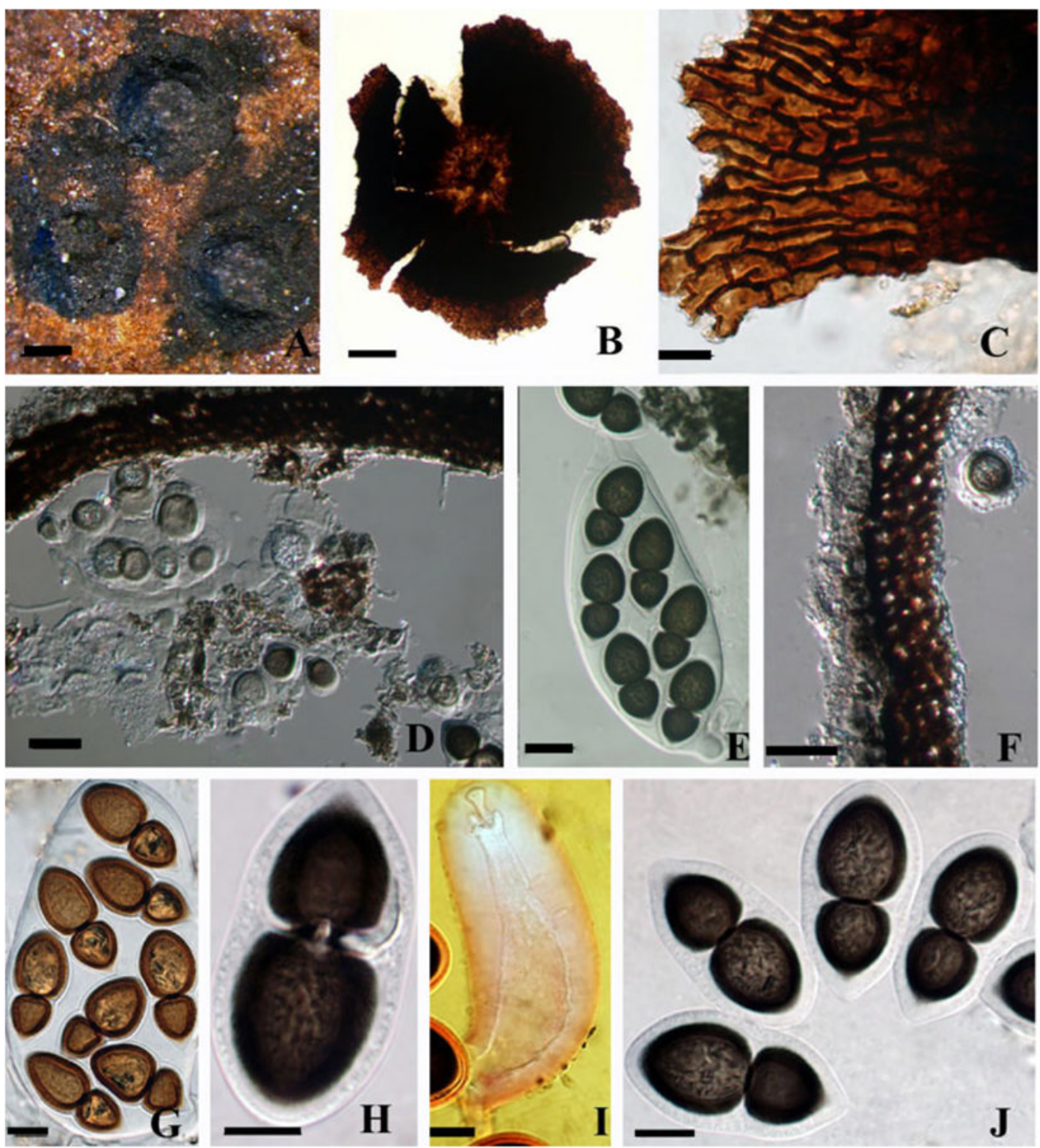

Fig. 30. Seynesiopeltis tetraplasandrae (holotype)

a Appearance of ascomata on the host surface. b Squash mount of ascoma. $\mathbf{c}$ The part of scutate structure. f Peridium. d Section of ascoma. e, g, i Asci. Note E, G in water and I in Congo red. $\mathbf{h}, \mathbf{j}$ Ascospores. Note the larger basal cell and apical cell which constricted at septate. Scale bars: $\mathrm{A}=200 \mu \mathrm{m}, \mathrm{B}=5 \mu \mathrm{m}, \mathrm{C}, \mathrm{G}, \mathrm{H}, \mathrm{I}, \mathrm{J}=10 \mu \mathrm{m}, \mathrm{D}, \mathrm{E}, \mathrm{F}=20 \mu \mathrm{m}$ 
Table 1

Various treatments of Microthyriaceae

\begin{tabular}{|c|c|c|c|}
\hline Müller and von Arx 1962 & Hawksworth et al. 1995 & Lumbsch and Huhndorf 2010 & This paper \\
\hline Arnaudiella & Actinomyxa & Actinomyxa & Arnaudiella \\
\hline Asterinella & Actinopeltis & Actinopeltis & Calothyriopsis \\
\hline Asterinema & Arnaudiella & Arnaudiella & Caribaeomyces \\
\hline Calothyriopsis & Asterinella & Asterinella & Microthyrium \\
\hline Caudella & Asterinema & Asterinema & Palawania \\
\hline Cyclotheca & Asteritea & ?Asteritea & Paramicrothyrium \\
\hline Dothidella & Asteronia & Asteronia & Seynesiella \\
\hline Maublancia & Byssopeltis & Byssopeltis & \\
\hline Munkiella & Calothyriopsis & Calothyriopsis & \\
\hline Microthyrium & Caribaeomyces & Caribaeomyces & \\
\hline Palawania & Caudella & Caudella & \\
\hline Polycyclinopsis & Cirsosina & ?Cirsosina & \\
\hline Seynesiopeltis & Cirsosiopsis & Cirsosiopsis & \\
\hline \multirow[t]{26}{*}{ Xenostomella } & Cyclotheca & Cyclotheca & \\
\hline & Dictyoasterina & Dictyoasterina & \\
\hline & Govindua & Govindua & \\
\hline & Helminthopeltis & ?Helminthopeltis & \\
\hline & Hidakaea & ?Hidakaea & \\
\hline & Hugueninia & ?Hugueninia & \\
\hline & Lembosiella & ?Lembosiella & \\
\hline & Lichenopeltella & Lichenopeltella & \\
\hline & Maublancia & Macrographa & \\
\hline & Microthyrium & Maublancia & \\
\hline & Monorhizina & Microthyrium & \\
\hline & Muyocopron & Muyocopron & \\
\hline & Pachythyrium & Pachythyrium & \\
\hline & Palawania & Palawania & \\
\hline & Petrakiopeltis & ?Petrakiopeltis & \\
\hline & Phaeothyriolum & Phaeothyriolum & \\
\hline & Phragmaspidium & ?Phragmaspidium & \\
\hline & Platypeltella & Platypeltella & \\
\hline & Polycyclinopsis & Polycyclinopsis & \\
\hline & Polystomellina & ?Polystomellina & \\
\hline & Resendea & ?Resendea & \\
\hline & Sapucchaka & ?Sapucchaka & \\
\hline & Scolecopeltidium & ?Scolecopeltidium & \\
\hline & Seynesiella & Seynesiella & \\
\hline & Seynesiopeltis & Seynesiopeltis & \\
\hline & Stegothyrium & ?Stegothyrium & \\
\hline
\end{tabular}

Fungal Divers. Author manuscript; available in PMC 2012 December 1. 


\begin{tabular}{llll}
\hline Müller and von Arx 1962 & Hawksworth et al. 1995 & Lumbsch and Huhndorf 2010 & This paper \\
\hline Tothia & ?Tothia \\
& Trichopeltella & ?Trichopeltella & \\
& Trichopeltina & ?Trichopeltina \\
Trichopeltospora & ?Trichopeltospora \\
Trichopeltum & ?Trichopeltum \\
& Trichothyriella & Trichothyriella \\
& Trichothyrinula & Trichothyrinula \\
& Trichothyriomyces & Trichothyriomyces \\
& Trichothyriopsis & Trichothyriopsis \\
& Trichothyrium & Trichothyrium \\
& Xenostomella \\
\hline
\end{tabular}

Fungal Divers. Author manuscript; available in PMC 2012 December 1. 
Table 2

A summary of the taxonomic treatments in this paper placed in Microthyriaceae by Lumbsch and Huhndorf (2010)

\begin{tabular}{|c|c|}
\hline Genus & Treatment in this paper \\
\hline Actinomyxa & Stictidaceae \\
\hline Actinopeltis & Trichothyriaceae $(=$ Trichothyrium $)$ \\
\hline Arnaudiella & Microthyriales, Microthyriaceae incertae cedis \\
\hline Asterinella & Microthyriales, Microthyriaceae incertae cedis \\
\hline Asterinema & Asterinales, Asterinaceae (= Maublancia) \\
\hline ?Asteritea & Asterinales, Asterinaceae \\
\hline Asteronia & Venturiales, Venturiaceae \\
\hline Byssopeltis & Microthyriales, Micropeltidaceae (=Stomiopeltis) \\
\hline Calothyriopsis & Microthyriales, Microthyriaceae incertae cedis \\
\hline Caribaeomyces & Microthyriales, Microthyriaceae incertae cedis \\
\hline Caudella & Microthyriales, Micropeltidaceae \\
\hline ?Cirsosina & Asterinales, Aulographiaceae \\
\hline Cirsosiopsis & Venturiales, Venturiaceae \\
\hline Cyclotheca & Microthyriales, Microthyriaceae but illegitimate name \\
\hline Dictyoasterina & Venturiales, Venturiaceae \\
\hline Govindua & Asterinales, Asterinaceae \\
\hline ?Helminthopeltis & Rhytismataceae \\
\hline ?Hidakaea & Hypocreales incertae cedis \\
\hline ?Hugueninia & $=$ Cyclotheca \\
\hline ?Lembosiella & Asterinales, Aulographiaceae \\
\hline Lichenopeltella & Trichothyriaceae \\
\hline Macrographa & Trichothyriaceae \\
\hline Maublancia & Asterinales, Asterinaceae \\
\hline Microthyrium & Microthyriales, Microthyriaceae \\
\hline Muyocopron & Dothideomycetes genera incertae cedis \\
\hline Noemicrothyrium ${ }^{*}$ & Microthyriales \\
\hline Pachythyrium & Trichothyriaceae? \\
\hline Palawania & Microthyriales, Microthyriaceae \\
\hline Paramicrothyrium ${ }^{*}$ & Dothideomyetes genera incertae cedis \\
\hline ?Petrakiopeltis & Uncertain \\
\hline Phaeothyriolum & Asterinaceae incertae cedis \\
\hline ?Phragmaspidium & Micropeltidaceae incertae cedis \\
\hline Platypeltella & Asterinaceae incertae cedis \\
\hline Polycyclinopsis & Asterinales, Asterinaceae \\
\hline ?Polystomellina & Asterinales, Asterinaceae incertae cedis \\
\hline ?Resendea & Asterinales, Asterinaceae \\
\hline ?Sapucchaka & Botryosphaeriales incertae cedis \\
\hline ?Scolecopeltidium & Microthyriales, Micropeltidaceae \\
\hline
\end{tabular}

Fungal Divers. Author manuscript; available in PMC 2012 December 1. 


\begin{tabular}{ll}
\hline Genus & Treatment in this paper \\
\hline Seynesiella & Microthyriales, Microthyriaceae incertae cedis \\
Seynesiopeltis & Dothideomyetes genera incertae cedis \\
?Stegothyrium & Ascomycota genera incertae cedis \\
?Tothia & Venturiales \\
?Trichopeltella & Uncertain \\
?Trichopeltina & Doubtful \\
?Trichopeltospora & Asterinales, Asterinaceae \\
?Trichopeltum & Uncertain \\
Trichothyriella & Microthyriaceae incertae cedis \\
Trichothyrinula & Microthyriaceae incertae cedis \\
Trichothyriomyces & Trichothyriaceae \\
Trichothyriopsis & Trichothyriaceae \\
Trichothyrium & Trichothyriaceae \\
Xenostomella & Asterinales, Asterinaceae \\
\hline * &
\end{tabular}

Fungal Divers. Author manuscript; available in PMC 2012 December 1. 